\title{
THE PRONUNCIATION OF MISSOURI PLACE-NAMES
}

\section{A Thesis}

Presented to

the Faculty of the Graduate School

University of Missouri

In Partial Fulfillment

of the Requirements for the Degree

Master of Arts

by

Donald George Picinich, A.B.

August 1950 
Custom is the most certain mistress of Language, as the public stamp makes the current money. . . . Yet when I name custom, I understand not the vulgar custom: for that were a precept no less dangerous to Language, than life, if we should speak or live after the manners of the vulgar: but that I call custom of speech, which is the consent of the learned; as custom of life, which is the consent of the good.

Ben Jonson, "D1scoveries" 


\section{ACKNOWLEDGMENT}

To Dr. Earl F. English, Associate Dean of the School of Journalism, the writer wishes to express his thanks for suggesting this investigation initially.

Thanks are due as well to Dean Frank Luther Mott and Professor Edward C. Lambert for their patience and valued suggestions during the course of this project.

Special thanks are due also to Dr. Robert I. Ramsay of the Department of English for his continuous and invaluable assistance in helping with the linguistic problems encountered and for his interest in seeing this work brought to a successful conclusion.

The assistance of Missouri radio news editors who co-operated in the over-all investigation and those interested persons outside the state and industry who likewise helped in this project is also gratefully acknowledged. 


\section{PREFACE}

With the current nationwide acceptance of the daily newscast as an integral part of American journalism, radio news editors have become increasingly aware in recent years of the importance in having their newscasters pronounce a local place-name in the usual manner of the educated speakers of that locality whenever a questionable name must be included in a 'cast. The major news services which offer their clients teletype news written especially for radio already have helped the newsman in sending out over their wires a dally pronunciation guide on the most difficult national and international names. These lists, both proper and place names, have their usual pronunciation indicated in a simplified phonetic key alongside each name. They serve a useful purpose in the radio news script, as far as they go. Unfortunately, the press services leave the matter of local pronunciation verification almost wholly up to each station itself, thinking that the station is in the best position to verify the usual place-name pronunciations in its own locality.

Th1s assumption, perhaps reasonable in theory, often falls short in practice, since in many cases station personnel makes a minimum effort to check, first-hand, the usual local pronunclations. In some states, however, this situation has been alleviated in large measure by state 
university investigations of the usual local place-name pronunciations. To date, Iowa, Illinois, Kentucky, Wisconsin, and South Dakota have completed place-name pronunciation guides which are being used successfully by broadcasters in those states and throughout the nation. Other states, including Indiana and Florida, among others, presently are engaged in such investigations, while some other states plan to begin such projects in the near future.

Missouri radio men, long award of the need for such a guide in this state, on numerous occasions have requested that the School of Journalism undertake such an investigation. In an effort to satisfy these needs, this study was begun.

No attempt is made in this investigation to establish a final, infallible authority for every Missouri name listed. Rather, this project was undertaken to offer Missouri radio men and other interested persons a centralized source for verifying usual place-name pronunciations, based on the findings of this study. This investigation was not made with a view toward making it a clinical, study in phonetics or a scientific investigation of Missouri speech patterns or dialects.

By recommending each pronunciation in both the International Phonetic Alphabet symbols and a simplified respelling key in the thesis and guide booklet, an attempt 
has been made to satisfy scholars and laymen alike. It is hoped that in offering two keys in the booklet, the user will have the opportunity of verifying a pronunciation twice, the one key reinforcing the other, so to speak. 


\section{TABLE OF CONTENTS}

CHAPTER

I. THE PROBLEM AND DEFINITIONS OF TERMS USED. . . • I The problem. . . . . . . . . . . . 1 Statement of the problem . . . . . . . . I Importance of the study. . . . . . . . . 1 False Guides . . . . . . . . . . . . 3 Organization of remainder of the thesis. . . 9 II. REVIEW OF THE IITERATURE . • . . . . . • . . 12

Network pronunciation handbooks. . . . . . 13 State pronunciation guides . . . . . . 16 General literature on pronunciation for radio. 19 III. METHODS USED AND GROUPS STUDIED. • • • • • • • 29 Selection of radio stations questioned . . . 29 Comments on the questionnaire. . . . . . 30 Comments on personal inquiry . . . . . . 38 Comments on other Missouri place-name studies. 43 IV. COMPILING THE PRONUNCIATION GUIDE. • • • • • • 55 Establishing the simplified key. . . . . . 88 Selection and arrangement of contents. . . . 91

V. COMMENTS ON THE CORRESPONDENCE . . . . . . . 95 VI. CONCLUSIONS AND RECOMMENDATIONS. . . . . . . 123 BIBLIOGRAPHY . . . . . . . . . . . . . . . . 164 APPENDIX . . . . . . . . . . . . . . . . . 177 


\section{CHAPTER I}

THE PROBLEM AND DEFINITIONS OF TERMS USED

\section{THE PROBLEM}

Statement of the problem. It is the purpose of this investigation (1) to evaluate a part of the literature concerning place-name pronunclation guldes recently complied by radio networks, the press services, and state universities, in addition to the literature dealing with some phase of pronunciation as it concerns Missouri placenames or pronunciation for broadcast purposes, and to decide how much of this material is pertinent in helping to establish a place-name pronunciation guide for Missouri radio men; (2) to determine how many Missourl place-names should be included in the guide on the basis of questionnaire returns received, correspondence written, interviews conducted, and post card inquiries sent throughout the state; and (3) to establish a place-name pronunciation guide booklet for Missouri broadcasters and other interested persons which indicates, by means of a simplified set of key symbols, the accepted current pronunciation of a selected number of c1ty, town, village, and river names and the county in which each place is located.

Importance of the study. From the numerous 
inquirles made already to the School of Journalism as to how soon Missouri broadcasters might expect such a guide, it is evident that a considerable number of radio men need such a guide. The fact that an increasing number of other states have recently met the needs of their radio stations along this line makes this investigation an important contribution to a nationwide trend. Also, in offering this service to the state's radio industry, the school of Journalism demonstrates once again 1 ts desire to keep abreast of the latest trends in the field of journalism. The importance of such an investigation has been emphasized further in recent years by the fact that several of the nation's major networks have engaged speech consultants to recommend acceptable pronunciations for both foreign and American place-names. Likewise, the press associations now issue daily place-name and proper name pronunciation guides for their radio station clients. On the local level, a number of state universities have issued pronunclation guide booklets within the past several years in an effort to satisfy the local radio man's desire to offer his listeners better public service by correctly pronouncing local place-names.

It is the hope of the National Association of Radio News Directors and other interested groups that eventually each state in the nation will issue a pronunciation guide 
for use by the local broadcaster and those stations in other parts of the country which might have occasion to refer to a less well-known place in another state. The United States Board on Geographic Names also is interested in these state investigations, although its work with American place-names has centered, to date, around problems of orthography rather than orthoepy.

Finally, this investigation has made some effort to present, in centralized form, the findings earlier recorded by the Department of English at the University of Missouri with respect to the actual and variant pronunciations of Missouri place-names. While not principally concerned with orthoepy, these eighteen Missouri place-names theses have provided a reliable source for a majority of the pronunclations listed in this guide.

\section{FALSE GUIDES}

Certain widespread superstitions about some one infallible method of determining the correct pronunciation of any place-name have been resisted firmly in this thesis. Among the more common misconceptions are: (1) that the pronunciation should always follow the spelling; (2) that American names borrowed from foreign lands or foreign languages should keep the same pronunciation used in their old homes or original tongues; (3) that colloquial 
pronunciation is substandard and to be avolded in careful speech; (4) that each syllable of the name should be pronounced as if it were a separate word, and (5) that there is only one "right" pronunclation of a name; or, if two or more variant pronunciations are found in the dictionary, the first always is preferable.

In his discussion of each of these general misunderstandings about the true values of any guide or standard to pronunciation, Fries quite correctly points to the fact that while spelling changes in the majority of English words have been comparatively few since the sixteenth century, pronunciation changes have been very great. As a result, the author cites the fact that "we have thus today a petrified system of spelling which very imperfectly represented the pronunciation of English during the time of Shakespeare but is now used to represent a twentieth century pronunciation." 1 Whereas the eighteenth century English speaker was advised by Dr. Johnson "to consider those as the most elegant speakers who deviate least from the written words,"2 the twentieth century speaker should carefully guard against any such thought. Such "spelling

1 Charles C. Fries, The Teaching of English (Ann Arbor: The George Wahr Publishing Co., 1949), p. 63.

2 Ibid., p. 63. 
pronunciations" usually have come about when the speaker takes a guess at the pronunciation, basing it on the name's spelling alone, and it is important that this practice be discouraged as much as possible. In radio news work, this error is not uncommon when the newscaster is hurried and the name is strange.

Retaining the original pronunciation of a foreign name for purposes of normal English conversation is, says Fries, impossible of consistent application. He writes:

It is really impossible for most of us to jump suddenly into the speech pattern of a foreign language in the midst of an English sentence. Our rendering of the pronunciation of a foreign word is, therefore, only approximately correct, rarely accurte. 3

citing as a case in point the word Paris, the author says that it is difficult to maintain the name's original pronunciation in view of its general use in this country. In this investigation, a number of the recorded pronunciations of European and Indian names are anglicized versions of the name's original pronunciation. These current pronunciations have been modified to conform to the standards of the region in which they are located.

In determining an acceptable English pronunciation standard, Fries recommends that the pronunciations common

3 Ibid., p. 65. 
In the usage of those in positions of influence and respect must furnish the basis. Stating his thesis categorically, he says:

First of all, the actual sound of the word as it is heard in the present usage of English speakers, not the spelling, not the etymology, must be the basis of all the 'correctness' there can be in pronunclation. The 'practical' standard of pronunciation must thus be the speech of those we actually 'hear. 14

Thus, despite the popular fallacy that colloquial pronunciation is substandard and to be avoided in careful speech, the term in this investigation refers solely to the usual pronunclation heard in the conversation of educated persons in that community. This term is not to be confused with common or improper speech, nor with "local" pronunciation.

The important matter of context is often overlooked by the average dictionary user in indicating either to himself or someone else how the word actually is pronounced when ranged alongside its fellows in a sentence. That lexicographers recognize such necessary modifications wrought by the position of a syllable in a word or of a word in a sentence, is found in the preface to one of our most reliable dictionaries. The editors write:

The difference between the pronunciation of a word when taken alone and as $1 t$ occurs in a sentence should also be kept carefully in mind; thus 'and'

$$
4 \text { Ibid., p. } 67
$$


considered alone is 'and,' but in such a combination as 'bread and butter' it is usually weakened to 'nd, or even ' $n_{j}$ ' $a$ ' in the phrase 'for a day' becomes 'uh, ' etc. 5

While these modifications may not be apparent to the average speaker, especially in the matter of place-names, such changes are found upon closer listening to the average person's conversational discourse. An example of this fact is found in the recommended pronunciation of the name, Oh10, by the radio news director of station KFUO, Clayton. Indicating the name is pronounced OH-HEYE-OH, it is apparent that the more natural pronunciation, oh-HEYE-Uh, was elther unknown to the director or that he did recognize this latter pronunciation as suitable for broadcasting purposes. 6

Variant pronunciations, while causing some confusion generally as to which is the most preferred, often are assumed by the average dictionary user to be aligned in order of preference. While this may be true to some extent generally, no effort has been made in this investigation to favor one pronunciation over the other by means of primary and secondary alignment in the thesis and guide booklet place-name listings. Agreeing with Fries in the matter of

5 Webster's New International Dictionary (1925),

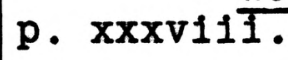

6 Questionnaire, December, 1949. 
these variant pronunciations, it has been felt in this study that even a superficial examination of the pronunciation of those speakers of English in positions of respect and influence reveals the fact that there are many differences in the pronunciations of different speakers. Expressing his viewpoint on this matter, Fries says:

Where this general spoken usage differs in respect to the sound of any word, no 'one' pronunciation is the 'sole' correct one. The several pronunclations in actual usage are thereby acceptable. In such cases of divided usage, however, a reasonable cholce may be made in accord with the following considerations: (a) in the matter of borrowed words, for that pronunciation which is in harmony with English sounds and English accent. (b) for that pronunciation which is in harmony with the tendencies of English speech in the matters of unstressed vowels, and organically phonetic assimilations of consonants. 7

In this study, the name, Missouri, offers a good example for which three variant pronunciations could be applied with equal validity, depending upon personal preference alone. In this guide, the pronunciations, muh-Z00-ruh, muh-Z00-ri, and mi-Z00-ruh are recommended equally. Since one pronunciation necessarily must precede the other, whatever the arrangement, no preference is intended in the matter of this or any other name having valid variant pronunciations.

7 Fries, op. c1t., pp. 69-70. 
III. ORGANIZATION OF REMAINDER OF THE THESIS

The second chapter of the thesis is a review of a part of the recent literature dealing with pronunciation and its importance in the radio industry. Reference is made in this chapter to the network pronunciation handbooks, state pronunciation guides, and the general

11terature on pronunciation for radio examined in this study .

Chapter III of the thesis includes a discussion of the materials used and the groups studied in this invest1gation. The call letters of the forty-four Missouri radio stations questioned in this study as well as a discussion of their replies to these queries are herein included. This chapter also includes comments on the post card inquiries made throughout the state and the personal inquiries made on campus in verifying the most doubtful place-name pronunciations. Some comment is made also on other Missouri place-name studies conducted within recent years. Emphasis is placed upon the important contribution made by the Department of English in completing eighteen master's theses dealing with Missouri place-name history in the main, but including some reference to Missouri pronunciations.

The fourth chapter of the thesis includes the compilation of the place-name pronunciation guide which is 
found in the sixth chapter of the thesis and in booklet form as issued by the School of Journalism. Reference is made herein to the several type phonetic keys used by local stations, the networks, the press services, and the states which have recently issued similar guides for their broadcasters. Some historical background on early gazetteer and dictionary phonetic keys is included here also.

Chapter $V$ of the thesis is a review of the comments written by Missouri radio men and other interested persons throughout the nation with respect to this investigation. This chapter includes interesting and significant remarks made by persons not in the radio industry when those comments are pertinent to this study.

The sixth chapter of the thesis discusses the conclusions reached from this investigation as to the need for such a place-name pronunciation guide and includes the master list of a selected number of Missouri and neighboring state place-names. Each name's accepted current pronunciation or pronunciations, so far as it has been possible to determine them, are listed, first in the phonetic symbols of the broad form of the International Phonetic Alphabet, and secondly by the simplified respelling method described in the fourth chapter. The master list, using both systems of indicating pronunciations side by side, has been reprinted by the School of Journalism. 


$$
[
$$




\section{CHAPTER II}

REVIEW OF THE LITERATURE

The literature dealing with place-name pronunciation for radio is limited in general. There are only a few handbooks, state guides, and chapters in general works which refer specifically to place-name pronunciation. In the case of one of the network handbooks, place-names are included as only a part of the vocabulary as a whole. Most of the compilations in the handbook of another network emphasize foreign place-name pronunciations, only occasionally including American place-names and then only when those names present an obvious pronunciation problem. Most of the state guides that have been issued to date vary in the matter of selection of contents. Some include every placename in the state regardless of whether or not that name presents a pronunciation problem. Others include timelimited proper names of city, county, and state officials. Few agree completely as to the phonetic symbols recommended in the respelling key, although some efforts at standardization of this simplified respelling system may be seen in the most recent state guides. Most of the general literature that includes some reference to pronunciation for radio broadcasting purposes gives little direct attention to place-name pronunciation. When this category 
is mentioned, the author usually cltes foreign place-names in his discussion, with but an occasional remark or two on American place-names.

There are four network pronunciation handbooks which are recommended generally for both laymen and specialists when investigating place-name pronunciations. Two of them are the official recommendations of two of the nation's leading networks. A third, the oldest and perhaps the most universally known, was issued by the British Broadcasting Corporation as a series of seven pamphlets, each containing troublesome place-names in the $\mathrm{BBC}$ home service coverage area. The fourth network handbook, that issued by the Canadian Broadcasting Corporation a few years ago, includes a selected vocabulary list, some musical terms, and a general name list in addition to a wide selection of Canadian place-names.

E1ther purposely or by accident, the National Broadcasting Company and the Columbia Broadcasting System 1ssued pronunciation handbooks in the same year. The former work, complled by James F. Bender, is the NBC Handbook of Pronunciation. ${ }^{1}$ Like its CBS counterpart, War

1 James F. Bender, NBC Handbook of Pronunciation (New York: Thomas Y. Crowel1 Company, 1943), $289 \&$ \&111 pp. 
Words, 2 compiled by W. Cabell Greet, the NBC handbook appeared in 1943. Although both works appeared at this time largely to meet the exigencies of the war, their value to post-war demands has been such that both authors have brought forth more comprehensive editions in late years.

While including a selected vocabulary in addition to American and forelgn place-names which might offer pronunclation difficulty, Bender clearly shows that the latter category occupies the paramount consideration in establishing his guide. In the foreword he says, "Innumerable place names--many of them indigenous to languages other than English--have to be dealt with, and the broadcaster's task, already sufficlently difficult, has been made very much more trying." 3 Greet likewise devotes the major portion of his work to the forelgn place-names made prominent by the war, but he does include domestic names which offer some pronunciation problem. The CBS speech consultant likewise devotes considerable effort to including variant pronunciations on local place-names while the NBC compiler offers but one recommendation per name. That Greet considers the inclusion of variant pronunciations to be important in the compliation of the CBS guide is evident when he says:

2 W. Cabell Greet, War Words (New York: Columbia University Press, 1943), 137 pp.

3 Bender, op. c1t., p. vi1. 
Included with the names that the War has made prominent are certain common English words whose alternative pronunciations cause domestic conflict of a different order. The debates as to which pronunciation is 'correct' can be settled only by future generations, for in 1943 these words actually have two or more pronunciations and each of them is held by millions of Americans to be 'correct.' It is not the province of CBS to regulate the English language, but it is desirable to avoid the awkwardness that conflicting pronunciations on one program may cause. 4

The series of seven BBC pamphlets entitled Broadcast English was complled by Professor Arthur Lloyd James of the School of Ordental Studies, University of London. 5 Beginning his compilation in 1932, Lloyd James completed the series in 1939. As does the $\mathrm{NBC}$ handbook, the BBC guides recommend but one pronunciation for each name. Also, as with its American counterpart, the BBC series employs both the International Phonetic Alphabet symbols and a simplified respelling key, differing from the CBS handbook which uses diacritical markings and respellings.

$$
\text { Canada's Handbook for Announcers }{ }^{6} \text { complled for use }
$$
by the personnel of the Canadian Broadcasting Corporation

4 Greet, op. c1t., p. 5.
5 Arthur Lloyd James, Broadcast English (London: The British Broadcasting Corporation, 1932-1939), circa 190 pp.

6 W. H. Brodie, Handbook for Announcers (Toronto: The Canadian Broadcasting Corporation, 1946), $52 \mathrm{pp}$. 
by W. H. Brodie, Supervisor of Broadcast Language, in 1946, is the most recent network handbook investigated in this study. Somewhat resembling its CBS predecessor in its inclusions of a diacritical respelling key, this work contain a carefully selected list of general words, musical terms, and proper names as well as a large number of Canadian place-names. This work, like its American and British counterparts, evidences an effort on the compiler's part to make the book as inclusive and generally practical as possible. In addition to recommended pronunciations, the CBC handbook gives considerable attention to other important problems faced by the newscaster and announcer such as articulation, stress, speech standards, and basic microphone techniques.

State pronunciation guide booklets. As in the case of the network pronunciations handbooks, there are a limited number of state guides which have appeared to date. Those examined in this investigation are Wisconsin Place Names by Harold A. Engel, 7 Pronunciation Guide to Iowa Place Names by Arthur M. Barnes, 8 Pronunciation Guide for Illinois

7 Harold A. Engel, Wisconsin Place Names (Madison: University of Wisconsin, 1948), $19 \mathrm{pp}$.

8 Arthur M. Barnes, Pronunciation Guide to Iowa Place Names (Iowa City: University of Iowa, 1948), 8 pp. 
Towns and Cities by Donald E. Brown and Frank E. Schooley, 9 Guide to the Pronunciation of Kentucky Towns and Cities by Niel Plummer, 10 and the South Dakota booklet, What's That Name? by Donald D. Burchard and Orrin Melton. ${ }^{11}$

Engel compiled the orlginal Wisconsin guide in 1938, editing the revised copy just ten years later. Whether this guide was the first such booklet issued by any state has not been ascertained definitely by the writer. However, if this was not the first of the state pronunciation booklets it was one of the first in the nation. Ilke the majority of network handbooks, this guide recommends but one pronunciation for each name. And, like the CBC and CBS works, the booklet employs diacritical marks to indicate the pronunciations. Establishing a sound precedent in the matter of determining speech standards for his guide, Engel writes, "In speaking to Wisconsin people in Wisconsin communities it is most important that place-names be pronounced correctly. Nothing destroys a listener's

9 Donald E. Brown and Frank E. Schooley, Pronunciation Guide for Illinois Towns and Cities (Urbana: University of IIIinois 1948), 52 pp.

10 Niel Plummer, Guide to the Pronunciation of Kentucky Towns and Cities (Lexington: University of Kentucky, 1949), 52 pp.

11 Donald D. Burchard and Orrin Melton, What's That Name? (Brookings: South Dakota State College, 1949), 10 pp. 
confidence in an announcer or a speaker more quickly than mispronunciations. The pronunciations offered here are based on local preference and usage."12

The Iowa booklet differs from the other state guides in that variant pronunciations are offered where necessary and several simplified respelling symbols are included which do not appear in the earlier or later booklets. Unfortunately, this work has had a limited content in its infial issue in an effort to meet the immediate needs of Iowa radio newsmen. However, supplements have been compiled at later dates in order to include all troublesome names in time. In the foreword, the compiler points out that a permanent guide is planned once all pronunciations have been approved and accepted by the state's radio industry.

The Illinois booklet, like that of Kentucky, includes every state place-name whether or not that name presents a pronunciation problem. This total inclusion seems unnecessary with such names as Smithboro, Smithfield, Taylor Springs, etc. The simplified key used in the Illinois and Kentucky guides is Identical in both booklets and is an improvement over that offered in the Wisconsin

12 Engel, op. cit., p. 2. 
and Iowa booklets with respect to clarity and accuracy. The Kentucky guide, in addition to a total inclusion of city, town, and village names, indiscriminately lists every county name in a separate listing whether or not the name offers a pronunciation challenge. This again seems unnecessary when such names as Bell, Butler, Clay, and Green are included.

South Dakota's booklet, while meriting praise for its selective listing of that state's place-names most often mispronounced, has the obvious weakness of not including a phonetic key to indicate the English equivalents for the symbols offered. This work, like 1ts Iowa predecessor, also includes pronunciations of the names of prominent persons in the state. While perhaps having a current value, this practice tends to decrease the permanent value of the total work since state offices change hands frequently and new names must be appended constantly for current worth. This could prove to be a steady assurance of employment for the printer, but might prove considerably tiring for the compiler in time.

General I1terature on pronunciation for radio. Since many books dealing in whole or in part with pronuncia tion of general vocabulary and place-names were written prior to the advent of commercialized broadcasting's national ascendency, the general literature on 
20 pronunciation for radio is limited somewhat. The most recent books on radio news generally include some mention of the increasing importance which pronunciation has assumed in effecting better news dissemination oraliy.

The most recent books which include some discussion of pronunciation for radio are Handbook of Broadcasting by Waldo Abbot, 13 News by Radio by Mitchell V. Charnley, 14 World Words by $W$. Cabell Greet, ${ }^{15}$ The Radio Announcers Handbook by Ben $G$. Henneke, 16 Effective Radio Speaking by William G. Hoffmann and Ralph D. Rogers; American Place Names by Alfred H. Holt, ${ }^{18}$ A Manual of Radio News Writing by Burton L. Hotaling, 19 A Pronouncing Dictionary of

13 Waldo Abbot, Handbook of Pronunciation (New York: McGraw Hill Book Company, Incorporated, 1941), 422 \& $x 1 \mathrm{pp}$.

14 Mitchell V. Charnley, News by Radio (New York: The Macmilian Company, 1948), $395 \mathrm{pp}$.

15 W. Cabell Greet, World Words (New York: Columbia University Press, 1948), $608 \mathrm{pp}$.

16 Ben G. Henneke, The Radio Announcers Handbook

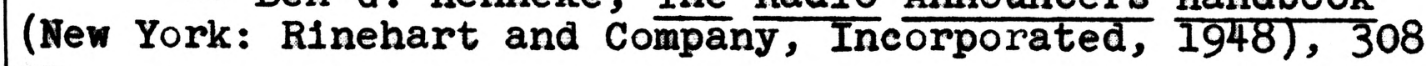
pp.

17 William G. Hoffmann and Ralph L. Rogers, Effective Radio Speaking (New York: McGraw Hill Book Company, Incorporated, 1944), $241 \mathrm{pp}$.

18 Alfred H. Holt, American Place Names (New York:

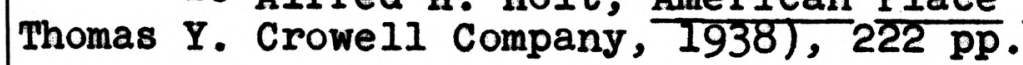

19 Burton L. Hotaling, A Manual of Radio News Writing (Milwaukee: The JournaI Company, 1947), $62 \mathrm{pp}$. 
American English by John S. Kenyon and Thomas A. Knott, 20 Pronunciation, A Practical Guide to American Standards by Thorlief Larsen, 21 The Broadcast Word by Arthur Lloyd James, 22 Radio Journalism by Paul H. Wagner, 23 Radio News Writing and Editing by Carl Warren, ${ }^{24}$ and News on the Air by Paul H. White. 25

Abbot includes one chapter on radio pronunciation, 26 which, although it devotes considerable attention to general vocabulary pronunciation problems, pays little heed to place-name pronunciations on the local level. Some discussion is made of foreign names in the news, and the author points out the more important facts to be considered

20 John S. Kenyon and Thomas A. Knott, A Pronouncing Dictionary of American English (Springfield: G. \& C. Merriam Company, 1944), 484\& 111 pp.

21 Thorlief Larsen, Pronunciation, A Practical Guide to American Standards (London: Oxford University Press, 1930, $198 \mathrm{pp}$.

22 Arthur Lloyd James, The Broadcast Word (London: Paul, Trench, Trubner and Company, Itd., 1935 $\overline{1,207}$ pp.

23 Paul H. Wagner, Radio Journalism (Minneapolis: Burgess Publishing Company, 1940), $135 \mathrm{pp}$.

24 Carl Warren, Radio News Writing and Editing (New York: Harper and Brothers, 1947), 439 pp.

25 paul W. White, News on the A1r (New York: Harcourt, Brace and Company, 1947), $396 \mathrm{pp}$.

26 Abbot, op. cit., Chapter III. 
In pronouncing foreign place-names and foreign proper names. This chapter is mainly important with respect to its comprehensive references to other works on pronunciation for radio given at the end of the chapter.

Although he devotes much attention to the many other ramifications of the important facets of radio news work, Charnley makes little direct mention of radio pronunciation in his book. This work, however, is excellent in its thorough treatment of many important details in the field in general. 27

The second, considerably enlarged, edition of the CBS handbook 28 pays noticeably more attention to American place-name pronunciation than did 1ts 1944 predecessor of the same title. Included in this work are a selected number of Missourl place-names, with variant pronunclations recommended on these as well as the other place-names where necessary.

One of the best of the texts on radio news which includes a well-developed discussion of pronunciation for radio is that by Ben $G$. Henneke, professor of speech at the

27 Charnley, op. cit., p. 114 .

28 Greet, op. c1t., pp. 1-608. 
University of Tulsa. 29 Not only is the author well aware of the present and future importance which prnnunciation of general vocabulary and place-names in the United States holds for radio, in view of his own lengthy experience, but he also is informed adequately on the opinions of other national figures in the industry on this subject. The author expresses himself clearly and interestingly on the whole matter of pronunciation for both general announcing assignments and for the more specialized field of radio journalism. He includes in his discussion references to the current systems of phonetic representation used by the major networks, pointing out both the strong and the weak points of such systems. This book is valuable for both old timers and newcomers to the production side of the radio industry.

Hoffman and Rogers, in concert with the majority of radio speech texts, place much emphasis upon enunciation, controlled breathing, reading for meaning, and recommended microphone techniques in addition to some pertinent remarks on pronunciation. Iftte of value was found in this work with respect to elther foreign or American place-name pronunciation problems or solutions. The authors do discuss briefly the merits of consulting the dictionary for

29 Henneke, op. c1t., p. 22. 
recommended pronunciations, but their arguments offer no new insights into a subject already thoroughly discussed in similar texts. 30

A good source for recommended Missourl place-name pronunciations is the compiliation made by Holt in 1938.31 While probably not including these names for broadcasting purposes exclusively, the author indicates each pronunciation in a clear interesting manner which appeals primarily to the lay reader. The author employs the popular system of "rhymes w1th" for each place-name in the book, his recommendations being based upon an extensive automobile trip across the country in which he recorded personally each pronunciation in that locality. Far from being comprehensive in 1ts contents, the work is of value to the reader who is seeking a reliable authority for a specific pronunciation that has been included by Holt.

While for the most part the text by Hotaling is one of the best of the current series on radio news mechanics, the brief allusions made by the author to the whole problem of recording clear and accurate place-name pronunciations, both foreign and domestic, over-simplify the entire procedure for the average student or layman. In glibly explaining that phonetic spelling is no more than simply

30 Hoffman and Rogers, op. cit., pp. 150-151. 31 Holt, op. c1t., pp. 1-222. 
spelling out each syllable as it sounds, 32 the author either unconsciously or deliberately forgets to point out that different persons hear sounds differently and that the untrained listener is likely to misinterpret the sounds he hears. Again, in mentioning that pronunciation word books and the dictionary are one's guides for radio pronunciation, Hotaling indicates no particular guide or guides nor does he tell the untrained reader where these sources may be found. For local names, the author suggests that the newscaster can make up his own pronunciations. This suggestion could prove disastrous in cases where the newsman is a newcomer and the name is strange.

Potentially, the most valuable book in this group is the dictionary of general vocabulary, proper names, and place-names compiled by the eminent lexicographers and phoneticians, John S. Kenyon, author of the standard handbook on American pronunciation, and Thomas A. Knott, editor of the Second Edition of Webster's New International Dictionary. The authors have spared no effort in setting down the most usual pronunciation heard in cultivated usage for each name in the book. The master listing includes a

32 Hotaling, op. cit., pp. 2l-22. 
considerable number of Missouri place-name pronunciations. Unfortunately, the compilations have an undoubtedly limited readership at present in view of the fact that each pronunciation is indicated in the symbols of the International Phonetic Alphabet alone. Since many dictionary users either will not or cannot learn to interpret these symbols with any degree of facility, the book automatically limits its appeal to those who have learned or who are willing to learn the IPA alphabet. But it is to be hoped that in time all radio newsroom personnel will feel as free to make use of this splendid work, as most now do in consulting Webster's or one of the other standard dictionaries. The preface to the Dictionary is especially valuable in helping the student and layman to understand better the problems faced by pronunciation guide compilers and to comprehend more clearly the meaning of spelling pronunciation, variant pronunciation, regional pronunciation, and anglicization. Larsen's book, which includes a brief remark or two on pronunciation for radio, is of primary value to the reader of today in giving him some idea of the recognized importance of pronunciation in the radio industry twenty years ago or more. The author demonstrates a sound appreciation for terminology in his discussion of pronunciation standards in the establishing of any guide to pronunciation 
for radio or any other purpose. 33

Arthur Lloyd James' book, The Broadcast Word, is indispensable for the layman or scholar in helping him to get a complete picture of the major and the minor considerations that must be thoroughly weighed by a pronunciation guide compller before elther undertaking or completing his chosen assignment. Lloyd James, despite personal modesty, heads the group of modern orthoepists who have devoted a large portion of their experience and energy to standardizing the methods of procedure to be followed in recommending pronunciations for radio broadcasting purposes. His detalled description of the compilation of the first of his seven pamphlets on broadcast English, forms a major portion of this book, published before his serles was completed in 1939. Although the author devotes his attention to United Kingdom place-names, the contents of this work are of primary value to anyone contemplating a similar investigation anywhere in the world. Written in an easily understood, straightforward style, the author's recommendations in this work have formed a sound basis for the later efforts of Greet and Brodie on this continent.

Like Larsen some ten years before, Paul H. Wagner's inclusion of a brief reference to pronunciation for radio is helpful to the student in understanding general newsroom

33 Larsen, op. cit., p. 17. 
practices. Although some simplified pronunciations of forelgn proper and place-names, then news-worthy, are offered, lack of explanation of the phonetic key used and of a more detalled description of actual newsroom procedure in handling place-name pronunclations on the local level cause this book to have a limited value in this investigation. 34

The text by Warren devotes two general paragraphs to pronunciation for radio. It is largely a warmed-over discussion of points already brought up in other radio news textbooks.35 This work has litte specific value for the student or general reader interested in orthoepy, since no examples of the several brief points discussed are offered.

Paul White's efforts appear to be directed primarily at popular consumption, with his inclusion of many different aspects of radio news work, forming a patchwork quilt background for a generalized presentation of a highly integrated series of specific operations. From the standpoint of this study, his brief remarks on radio pronunciation offer nothing new in the way of helpful information to anyone who is familiar with any other recent book on radio news techniques.

\footnotetext{
34 Wagner, op.c1t., pp. 101-102.

35 warren, op. cit., p. 163.
} 
METHODS USED AND GROUPS STUDIED

The methods used and the groups studied in this investigation consisted of (1) a questionnaire sent to every Missouri radio station listed in the 1949 edition of Broadcasting Yearbook ${ }^{l}$; (2) forty-one double post cards sent to county superintendents of school residing in those areas in which the most questionable place-names listed in the thesis are located; (3) personal inquiries made on the campus by the compiler which consisted of interviewing student residents from either the place in question itself or students who are from the county in which that place is located, and (4) personal investigation of the eighteen master's theses on Missouri place-names, begun by the Department of English of the University of Missouri in 1928 and completed in 1945 under the direction of Dr. Robert L. Ramsay, national authority on Missouri place-name pronunciation.

Two works by national authorities on American pronunciation also consulted in this investigation were $\underline{A}$ Dictionary of American English by John S. Kenyon and Thomas

1 Broadcasting Yearbook (District of Columbia, Broadcasting Publications, Incorporated, 1949). 
A. Knott, 2 international authorities on American pronunciation, and American Place Names by Alfred H. Holt, 3 author of a popular compilation of American place-names, the recommended pronunciations of which are based upon an extended cross-country investigation made by the author several years ago.

of the forty-four stations queried, twenty-four responded, a total of 54.34 per cent. of this total, five stations did not indicate any place-names in their regional coverage area which were causing their newscasters and announcers pronunciation difficulties. Four stations included place-names of neighboring states along with troublesome names in Missouri. Two stations included many Missouri place-names which, while not in that station's coverage area, caused station newsmen difficulty in pronouncing on the air. One station, reversing the usual procedure in obtaining troublesome place-names for this study, requested the compiler to send them a list of place-names troubling him. This procedure proved most satisfactory in

2 John S. Kenyon and Thomas A. Knott, A Dictionary of American Engilsh (Springfield: G. \& C. Me rriam Company, 1944), 484 \& $111 \mathrm{pp}$.

3 Alfred H. Holt, American Place Names (New York: Thomas Y. Crowell Company, 1938), $222 \mathrm{pp}$. 
practice, and 1 is to be regretted that the five stations which did not indicate troublesome names did not see fit to follow this method at a later date. Stations indicating no troublesome place-names in their coverage area were station KLWT, Lebanon, Station KDRO, Sedalia, Station KICK, Springfield, Station WEW, St. Louis, and Station KTTS, Springfield. The number of names submitted by each respondent ranged from one to 100, the average being about twenty. Station KDMO, Carthage, listed but one place-name, Nevada, as being troublesome for its newscasters to pronounce. Station WDAF, Kansas City, listed the names of 100 Missouri counties, cities, towns, and villages which gave its personnel pronunciation difficulty, both on and off the air. Station KWTO, Springfield, a typical respondent, listed the names of sixteen towns and villages in its area which offered some pronunciation problems and included the names of four rivers in the area which proved troublesome in pronouncing. Station KCMO, Kansas City, reversing the usual method in obtalning troublesome names for this compilation, asked the writer to send its newsroom personnel a list of names in that part of the state which were proving troublesome to him in obtaining final verification on a given pronunciation. This request was fulfilled, and the results obtained proved an important adjunct to the investigation as a whole. 
In addition to asking each news editor to submit a list of troublesome place-names in that station's coverage area, with the station's usual method of indicating those names' pronunciation to the station newsroom personnel, two questions, one concerning the local sources consulted for place-name pronunciation verification, and the other concerning the relevancy of listener complaints recelved when a place-name is mispronounced, were asked. Nineteen of the forty-four stations questioned answered these queries. This is a total of 69.16 per cent responses from the stations answering this part of the questionnaire. Question one was subdivided into five parts, one or all of which might be checked by the respondent in indicating how his newsroom personnel verified usual local pronunciations. These categories were the dictionary, gazetteer, postal authorities, long-time residents, or other sources which the respondent might indicate in the space provided. Question two was divided into three groups, one of which was to be checked in indicating the frequency of complaints from listeners with respect to place-name mispronunciations. These divisions were listed as (1) frequently, (2) occasionally, or (3) rarely.

of the nineteen respondents, two stations did not reply to the first question at all. Five stations indicated that they consulted the dictionary either solely or 
chlefly in verifying pronunclations of local places. Two stations replied that they normally consult the dictionary and a gazetteer, while one station said that it checked only with the gazetteer. Another station indicated that its newsroom staff checked with the dictionary and the daily Associated Press pronunciation guide sent over the radio wire of that service. One station answering the question checked both the dictionary and the postal authorities as its chief sources for place-name pronunciations, while another respondent simply checked the latter category. One reply was helpful in citing the newspaper as a source for pronunciations in addition to that station's checking with the dictionary and gazetteer. One news editor, probably in an effort to be especially clear as to how his staff obtained local pronunciations, checked all five parts to the first question, writing for the third part, "Hey, Mac, how in hell do you pronounce this?" 4

One station which is located near southern Iowa reported that its newsroom personnel make frequent use of the Iowa place-name pronunciation guide booklet for verifying pronunciations in that state as well as checking with an atlas, the Associated Press pronunciation guide, and a Joplin.

4 Questionnaire, December, 1949, Station KFSB, 
gazetteer. Two stations, while not indicating that any of the suggested sources was consulted by their staffs, pointed out that their personnel checked with local contacts such as state troopers and rallroad men or with the station manager. One editor, although reporting that his coverage area pronunciation usage has been partially compiled to date, did not indicate to what extent this compllation had been carried-out or who had made the compilation. This station indicated no other suggested source as being checked by that staff.

As may be seen from Table I, the dictionary is most usually the consulted source for local pronunciation verification by the majority of stations answering this part of the questionnaire. The gazetteer ranks second, according to this survey, while personal inquiry at the source is listed as the third most usual method for verifying local place-name pronunciations. The newspaper is given as a source for pronunciations by only one respondent, and the recommendations of the Associated Press in this matter are followed regularly by but two respondents.

Obvious weaknesses from the replies received to this first question are found in the fact that no particular dictionary is referred to either in the questionnaire or in the replies. Since there are almost as many standard dictionaries as there are replies to this question, the 
TABLE I

TABLE ILLUSTRATING THE INDIVIDUAL STATION BREAKDOWN OF REPLIES TO QUESTION I OF SURVEY

Station Call Letters

and Wattage Power

Location

Source Indicated

WHB 10,000-watts

KWOS 250-watts

KDRO 250-watts

KLWT 250-watts

KDMO 250-watts

KICK 250-watts

KTTR 250-watts

KMOX 50,000-watts

KFRU 250-watts

KFUO 5,000-watts

KSIM 250-watts

WEW 1,000-watts

KWRE 250-watts

KBOA 1,000-watts

KFSB 5,000-watts

KHMO 5,000-watts

KGBX 5,000-watts

KTTS 250-watts

KXOK 5,000-watts
Kansas City

Jefferson City

Sedalia

Lebanon

Carthage

Springfield

Rolla

St. Louis

Columbia

Clayton

Sikeston

St. Louis

Warrenton

Kennett

Joplin

Hannibal

Springfield

Springfield

st. Louis nothing

nothing

dictionary

dictionary

dictionary

dictionary

dictionary

dictionary

gazetteer

dictionary

gazetteer

gazetteer

dictionary

AP guide

dictionary postal guide postal guide dictionary gazetteer newspaper dictionary gazetteer postal guide personal gazetteer AP guide personal Atlas personal personal personal 
responses leaves unanswered what dictionary or dictionaries were meant by the respondents and how many of them agree or differ in the matter of which dictionary to consult as a final authority. Although the fact is granted that the majority of the recent popular dictionaries do agree in most cases on the Missouri place-name pronunciations which they include in their gazetteers, it should be noted that disagreements do exist today which could cause a considerable number of variations in the recommendations aired by one station as compared with those of another. This discrepancy in authoritative recommendations is especially noticeable in the case of the state name itself. In failing to differentiate in the questionnaire and replies as to exactly which gazetteer was meant, the validity of the replies received is again somewhat weakened with respect to portraying a true picture of the source consulted by each respondent. It cannot be known from these responses whether the station consults the gazetteer recommendations found in the back of most dictionarles today, or whether one of the older individual gazetteers such as Lippincott's is the consulted authority.

A margin of strength, however, can be found in the specifically-indicated replies of several respondents to the fifth part of the first question in which such sources 
as state troopers, railroad employees, and the station manager were listed by the respondent. While these answers definitely limited the possibility of misunderstanding on the part of the respondent, these replies pose an important question in this investigation with respect to evaluating the personal qualifications of those sources in indicating the pronunciation correctly and in the ability of the station personnel to recelve and record that pronunciation in the correct manner.

All stations which replied to the first question of the questionnaire also answered the second question. Since this is somewhat shorter than its predecessor, obvious alignments appear more readily than in question one in the final tabulation.

No respondent indicated that the station received listener complaints frequently with respect to place-name mispronunciation on the local level. Twelve stations said that complaints were received rarely from listeners when a local place-name was mispronounced over the air. This is 63.15 per cent of the total number of stations answering this question. The remaining seven editors indicated that listener complaints on mispronunciation do occur occasionally. This is 36.63 per cent of the respondent stations.

One important weakness of the results obtained from 
this second question is that no provision was made in the questionnaire and no information was offered in the replies as to why the station's listeners do or do not complain when local place-names are mispronounced carelessly by a newscaster or announcer. Although many conjectures are possible as to why the majority of listeners in the respondent stations' areas does not audibly register dissatisfaction when the name is pronounced in other than the usual fashion, these theories have little place in this report. Although, at first glance, it might appear that the mispronunciation of local place-names by announcers on the air is of small concern to the average listener in Missouri generally speaking, these results offer encouragement to those interested in helping to correct present faults in this matter both from the speaker and listener standpoint. If these limited responses indicate anything with respect to this investigation, it is that apparently a large part of today's radio audience in this state needs almost as much guidance in learning to recognize place-name mispronunciation as do the announcers.

In an effort to verify the most ambiguous or completely unknown place-names included in the master list, forty-one double post cards were sent to county superintendents of schools in all parts of the state. Of this total, twenty-four replies were recelved, or 60.00 per cent 


\begin{tabular}{|c|c|c|}
\hline \multicolumn{3}{|c|}{ TABLE II } \\
\hline $\begin{array}{l}\text { Station Call Letters } \\
\text { and Wattage Power }\end{array}$ & Location & $\begin{array}{l}\text { Complaints } \\
\text { Indicated }\end{array}$ \\
\hline WHB 10,000 -watts & Kansas City & Rarely \\
\hline KWOS 250-watts & Jefferson City & Rarely \\
\hline KDRO 250-watts & Sedalia & Rarely \\
\hline KLWT 250-watts & Lebanon & Rarely \\
\hline KDMO 250-watts & Carthage & Rarely \\
\hline KICK 250-watts & Springfield & Occasionally \\
\hline KTTR 250-watts & Rolla & Occasionally \\
\hline KMOX 50,000-watts & St. Louis & Occasionally \\
\hline KFRU 250-watts & Columbia & Occasionally \\
\hline KSIM 250-watts & Sikeston & Occasionally \\
\hline WEW 1,000-watts & St. Louis & Rarely \\
\hline KFUO 5,000-watts & Clayton & Occasionally \\
\hline KWRE 250-watts & Warrenton & Rarely \\
\hline KBOA 1,000-watts & Kennett & Rarely \\
\hline KFSB 5,000-watts & Joplin & Rarely \\
\hline KHMO 5,000-watts & Hannibal & Rarely \\
\hline KGBX 5,000-watts & Springfield & Rarely \\
\hline KTTS 250-watts & Springfield & Rarely \\
\hline KXOK 5,000-watts & St. Louis & Occasionally \\
\hline
\end{tabular}


of the inquiries sent. The average number of names included on one card varied between one and two per county. In some cases, however, as many as five names were listed on one card.

Instructions to each superintendent, while uniform and brief, brought interesting and varied replies in some cases which indicated that perhaps the recipient had not read the simple instructions through carefully before replying. In a sincere effort to be extremely clear in indicating a pronunciation in their county, some respondents resorted to their own phonetic markings which, in a few cases, caused greater confusion than if they had not replied at all. Other superintendents, however, were most helpful in indicating clearly how a name was pronounced usually in their county by either simply encircling the offered version submitted by the compiler or else resorting to Websterian diacritics or the suggested respelling system used in the Missouri guide.

Interestingly enough, four respondents pointed out that the place-name submitted for their verification did not exist in that county. Since most of the names checked by post card inquiry were selected from the 1948 edition of 
Pocket Maps of Missouri, 5 a further check on these names was made with University students on campus who are residents of that town or county. Their affirmations of the superintendents' replies in every case would tend to indicate that the Rand McNally source was probably incorrect in its inclusion of those names in its otherwise generally satisfactory guide. It is possible that these places once existed in the counties indicated, but owing to an oversight on the part of the compllers, the break up of these towns at some past date was not properly noted. As a result, "ghost" names were included in the Rand McNally listing which actually no longer exist as towns in this state.

In cases where the post card replies proved to be unsatisfactory because of lack of clarity on the part of the recipient, the compller made an additional inquiry concerning these names of University of Missouri students from the area in question. The Columbia address and telephone number of each student to be questioned was obtained from the office of the Director of Admissions of the University. An arbitrary number of three students from each community or county in which the doubtful place-name

\footnotetext{
5 Pocket Maps of Missour1 (Chicago: Rand McNally \& Company, 1948), $46 \mathrm{pp}$.
} 
is located was decided upon as the minimum required for adequate results. A total of sixteen students was selected for this part of the investigation, each a resident of elther the town or county in which that town was situated. In view of the fact that few persons on campus were residents of the towns in question, most of the pronunciations recelved in this manner were from county residents in which that locality is found. Pronounciations which were obtalned from student residents of the doubtful place itself include the towns of Sarcoxie, Norborne, Brashear, Puxico, and Wakenda. Town names that were recelved from students residing in the county in which that place is situated, who stated that they were familiar with the usual pronunciation of the place in question, Include Duenweg, Owasco, Wien, Medoc, Chitwood, Abadyl, Koeltztown, Duquesne, and Asbury. County names verified in this manner were Maries, Chariton, Moniteau, and Pulask1.

Although 1t was hoped originally that these interviews with students on campus could be conducted in a central place, each student being asked to report there at a specific time for a personal interview, this possibility did not materialize owing to the numerous conflicts in arranging the meeting place and time to suit each interviewee. As a result, each person was interviewed on the 
telephone, this procedure comparing equally in results obtained with the few face-to-face meetings arranged initially.

Not every student included in the original and the revised list of local addresses was contacted because of his leaving school unexpectedly in some instances or through negligence in the case of others when asked to call back after a number of calls falled to locate them. In some instances, the students contacted did not recognize the name at all. Since the usual reaction in such cases was automatic, those names not recognized by any group of interviewees have been eliminated from the final listing. If a number of variants were received respecting one place-name, further investigation of other sources was made where possible.

Comments on other Missouri place-name studies.

Foremost of the investigations completed to date on Missourl place-names are the elghteen Master's theses done in the Department of English. This project, begun in 1928, devotes 1tself principally to carefully investigated accounts of the individual history of more than thirty-two thousand names. While the major portions of each investigation concerns such matters as the origin of the name, its importance in the region in which it is located, 
and its past and present orthography, if different, the earliest theses allotted little space to orthoepy. Later, however, pronunciation is accorded increased recognition in each thesis, found in each case in the third chapter in the section entitled, "Other Linguistic Features."

Such interesting orthoepic problems as "spelling pronunciation," shift in accent, and the evaluation of speech dialect in a certain region of the state form an integral part of the later works. Since this information was gathered, in all cases, by each candidate personally, this section affords the scholar and layman an invaluable source for orthoepic information on all areas of the state. one example of the painstaking thoroughness to be found in these later theses is seen in the observations of one investigator doing research in Southeast Missouri. In citing the commonly noted shift in accent from the original pronunciation to that of the local region, she writes:

The shift of accent is a common phonetic change which occurs when a foreign word is anglicized. New Madrid' became New Mad'rid and Decypri' became Decy'pri, or, to make a general rule, the accent shifted from the last syllable to the first. A shift of accent is also seen when the very 'avert' was converted into the noun, 'a'vert.' 
This shift is of primitiye Teutonic origin, probably occurring about 600 B.C.6

While the theses devoted increasing attention to such integral parts of the whole field of orthoepy as that described above, Allen Walker Read was contributing much to the investigation of Missouri pronunciations also. Early pointing out that the state presented great interest for the student of dialect, this distinguished philologist points out that it is preferable to say that there is dialect in Missouri rather than that there is a Missouri dialect. Citing the fact that the state presents a welter of speech-groups, including the French, German, and Negro, Read points to geographical factors as well in discussing the contributing factors to present Missourl dialect variations. Demonstrating an appreciation for the worth of place-names as an important and integral part of the general vocabulary, he says,

We sometimes forget that geographic names are as much a part of our vocabulary as the words that we use in every sentence. They must be learned and remembered like ordinary words, and they are subject to the same laws of language.7

6 Mayme Lucille Hamlett, Place-Names of Six Southeast Counties of Missouri (Columb1a: Unpub11shed Master's Thes1s, University of Missour1, 1938). p. 261.

7 Allen Walker Read, "Attitudes Toward Missouri Speech," Missouri Historical Review (Columbia: University of Missour1, July, 1935), p. 269 . 
Earlier, in an attempt to establish a standard for determining correctness in the pronunciation of placenames, Read presented his views on the matter to a national reading audience. Recognizing that a number of authorities exist with respect to serving as a basis for determining correct place-name pronunciation, the former member of the Department of English of the University of Missouri points out that in the final analysis usage of the better speakers in the place named ought to be the chlef determinant in the matter. 8 Like most scholars who have devoted much time and effort to determining the correct authorlty for place-name pronunclations, Read methodically eliminates such notable false guides to correctness as the etymological form of the name; legislative action on the part of the state in making one pronunciation "official" to the exclusion of all others; the spelling of a name, past or present; and finally the slavish dependence evidenced by many upon the offerings of dictionaries and gazetteers.

Devoting considerable attention to the basis of correctness in the pronunciation of the word "Missour1," Read recorded an elghteen page account of his findings on

8 Allen Walker Read, "The Basis of Correctness in the Pronunciation of Place-Names," American Speech, 8:42-46, February, 1933. 
the subject in American Speech. Sparing neither detail nor feelings, this account is probably the best to date concerning the whole historical problem which is still a puzzling and controversial matter with large segments of the state's population. While the author makes some point of including lengthy quotations from then prominent Missourians as to their favoring one pronunciation over another, the crux of his findings in this investigation is found in the final paragraphs of the article. 9

Giving emphasis in his discussion to the various local and national renderings of the final vowel sound in the state name, then and now the most potentially controversial issue both within and without Missouri, Read writes:

Whatever its origin, the "uh" ending has, in deflance of spelling, shown remarkable vitality. An actual counting of heads in Missouri would show, I belleve, that it has the decided majority, perhaps that of two-thirds. It is so wide-spread even elsewhere and so well supported by phonetic tendencies that in the present day it is passed on like any other non-spelling pronunciation. It is on the defensive, however, and most of those who normally use it admit readily that they do so incorrectly, except a certain group who hold that it is the most validly Missourian and maintain it against all criticism.10

9 Allen Walker Read, "Pronunciation of the word 'Missouri'", American Speech, 8:22-36, December, 1933.

10 Ibid., p. 35. 
In this attempt to cite majority usage as his authority for pronouncing the state name Mi-zoo-ruh rather than M1-zoo-r1, the author is quick to remark in the next sentence that the spelling, no doubt has been the main influence upon the smaller group of speakers who favor the short " 1 " ending over the "uh" termination. This latter group Dr. Read des1gnates as the "careful speakers," the "best educated," and the "prominent Missourians."

Summarizing the findings of his study, the author concludes :

Usage within the state of Missourl, which can be explained by normal speech tendencies, is to be considered the standard, rather than the factitious forms given in the so-called authorities. The defensible pronunciations, which invariably have the (z) sound rather than the (s), fall into three grades: (1) by less careful speakers, (Morvra) with the first vowel like the ' $a$ ' in 'about,' the second like the ' $u$ ' in 'push,' and the last like the ' $a$ ' in 'sofa;' (2) by more careful speakers (mo'surI) with the first vowel like the ' $a$ ' in 'about,' the second like the ' $u$ ' in 'push,' and the last like the ' $y$ ' in 'lonely,' and (3) by more careful speakers, (MI'zUrI), with the first vowel like the ' 1 ' in 'hit,' the second like the ' $u$ ' in 'rude' and the last like the ' $y$ ' in 'lonely.'Il'

Adding his views to the panorama of contention, $\mathrm{Dr}$. Robert L. Ramsay of the Department of English, University of Missouri, devoted no small amount of attention to the pronunciation of the state name when writing on Missouri

$$
11 \text { Ib1d., p. } 36 .
$$


place-name pronunciations several years ago. Having thoroughly investigated his subject as part of the statewide place-name investigations then well underway, he wrote:

- . we should give our preference, I belleve, to the 'natural' pronunciation of the name of our state - the way indicated by our great Missouri dramatist, August Thomas, in 1893 when he spelled the title of his play 'In Missoura.' Despite what school-teachers and lexicographers may say, this is undoubtedly the way in which the large majority of Missourians, cultured and uncultured alike, pronounce and have always pronounced the name. A respectable minority may, it is true, be heard to say 'Mizzoury.' Our attitude to these should be one of tolerance. They have probably been influenced by the speling fallacy, but their pronunciation is not entirely an artificial one. There is, however, certainly no reason why we should suffer from an inferiortty complex in their presence.

Ramsay, like Read, rejects the still-common practices of settling disputed place-name pronunciations by appealing to the spelling or to some "official" authority for final confirmation. Explaining the reasons for his stand regarding the first false guide, he notes, "All modern students of language reject this criterion, because it puts the cart before the horse. Spelling should follow pronunciation, not pronunciation spelling."13 In discussing

12 Robert L. Ramsay, "How Do You Say It?", The Missour1 Alumnus (Columb12: The University of Missouri Alumni Association, October, 1936), pp. 25-26.

13 Ib1d., p. 11. 
the second fallacy, the Missouri place-name authority points out that "official"pronouncements have value only so far as their authors are in touch with the real authority, the facts of local usage.

Perhaps one of the most interesting as well as enlightening phases of these recent Missouri place-name investigations is the historical attention accorded Missouri names by Read in his discussion of the pronunciation of place-names on the frontier in the early 19th Century. In referring to Worcester's early attempts to ascertain the usual pronunclation of a disputed or unknown place-name on the frontier, Read remarks on the fact that Edward Everett, the noted orator and scholar, in writing to the first American lexicographer to include a gazetteer in his dictionary, pointed out that "Missouri" was pronounced with "s" sound distinctly heard, although Everett conceded that "My-z00'-re" is heard. 14 Th1s, Read notes, is the earliest record by several decades of the volcing of the double 's.' Explaining the reason for th1s now seldom heard pronunciation of the state name, Read writes, "The sound (s) was originally found in the word, as borrowed from the Indians, but according to the working of the so-

14 Allen Walker Read, "The Pronunclation of PlaceNames on the Frontier," American Speech, 13:263-67, December, 1938. 
called 'Verner's law in English,' by which a spirant is volced before an accented vowel, the sound $(z)$ developed in its place."15 Interestingly enough, in his correspondence with Worcester, Everett comments on the fact that in his opinion the then-prevalent pronunciation of St. Louis omitted the final ' $s$ ' sound. From the results of the present investigation, this situation has been reversed with the passing of a little over one hundred years.

Evaluating the over-all results that might be expected in tabulating the questionnaire responses, the post card replies, the personal interviews made, and the many place-names thoroughly investigated by the eighteen researchers of the Department of English and included herein as listed where no possibility of doubt existed, Dr. Ramsay clearly establishes a standard for this and following investigations similar to 1t. In reaching the heart of the matter which must be recognized by every place-name pronunciation guide complier, he points out:

All differences in local pronunciation are eventually settled, we believe, not by majorities, but by the local leaders, the same people who settle other matters of usage, such as fashions in dress or in etiquette or in behavior. For language in the last analysis is nothing but a department of fashion.

15 Ib1d., p. 265. 
And regrettable as it may be, school-teachers and scholars are but seldom the final arbiters of fashion. 16

Although 1t would appear from the total results obtained from this part of the investigation that, on the whole, Missouri radio listeners are pleased generally with the place-name pronunciations currently rendered in newscasts and other programs, newscasters and announcers should never feel wholly complacent in this matter. For, as clearly shown above, pronunciation as a part of language, is simply a department of contemporary fashion. And, as with any fashion, the styles that are correct one day may change the next. Pronunciation, although admittedly modified more slowly than feminine raiment, does change and it is the broadcaster's duty to keep abreast of the times, making the necessary modifications in place-name pronunclations as well as with the general vocabulary. 


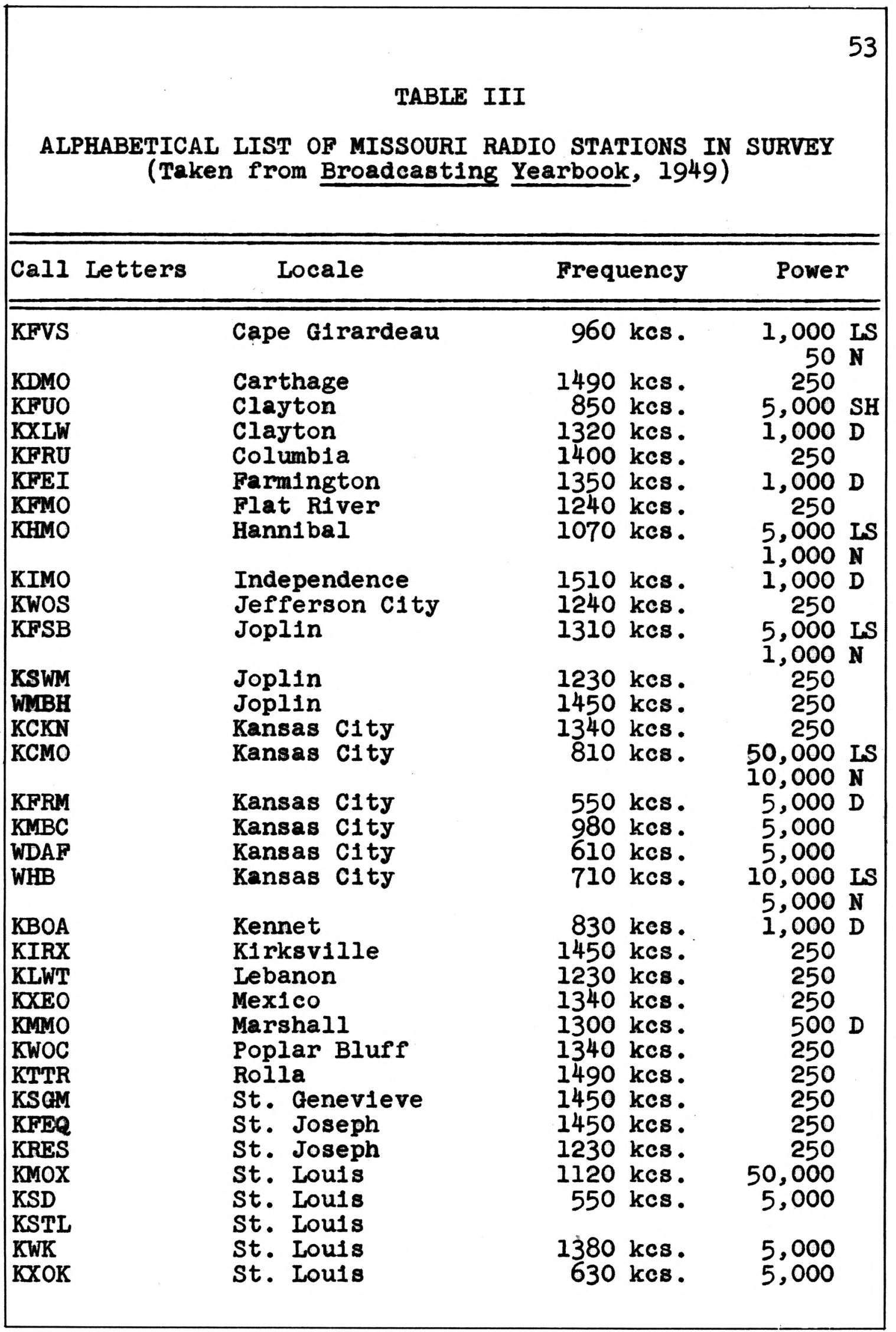


TABIE III (Continued)

\begin{tabular}{lllr}
\hline Call Letters & \multicolumn{1}{c}{ Locale } & Frequency & Power \\
\hline \hline WEW & St. Louls & $770 \mathrm{kcs}$. & $1,000 \mathrm{D}$ \\
WIL & St. Louis & $1430 \mathrm{kcs}$. & 5,000 \\
KDRO & Sedalia & $1490 \mathrm{kcs}$. & 250 \\
KSIM & Sikeston & $1400 \mathrm{kcs}$. & 250 \\
KGBX & Springfield & $1260 \mathrm{kcs}$. & 5,000 \\
KICK & Springfield & $1400 \mathrm{kcs}$. & 250 \\
KTTS & Springfield & & $5,000 \mathrm{LS}$ \\
KWTO & Springfield & & $1,000 \mathrm{~N}$ \\
KWRE & Warrenton & $1450 \mathrm{kcs}$. & 250 \\
KWPM & West Plains & & \\
\hline \hline
\end{tabular}




\section{CHAPTER IV}

COMPILING THE PRONUNCIATION GUIDE

The final page of the questionnaire sent to Missouri radio news editors was an attempt to ascertain how many stations use a simplified phonetic key for the vowel sounds and consonant combinations, similar to that of the press services and network pronunciation handbooks, and how many use a set of symbols such as those found in the dictionaries and gazetteers. It was also hoped that this page would indicate how many stations use a mixture of both systems to indicate colloquial place-name pronunciation and how many have no established key.

In attempting to find out each station's usual method of indicating the pronunciation in its regional coverage area, the questionnaire asked the radio news editor to discuss briefly how the station's key was devised. Of the total twenty-four replies, seven stations answered this question. Four replies were brief, but gave some indication as to how these stations originated their own simplified pronunciation keys. Station WHB, Kansas City, wrote, "AP system." Station KBOA, Kennett, mis-interpreting the question, said, "popular usage." Station KFRU, Columbia, wrote that its station key was patterned after the AP pronunciation guide sent 
out da1ly from Associated Press radio wire headquarters in New York City. ${ }^{1}$

Station KPUO, clayton, pointed out that it uses a phonetic system without diacritical markings over the vowel sounds. The KFWO news editor added that the station's key indicated the accented syllable in a name by either underlining or capitalizing the accented syllable, and in some cases, dolng both to the same syllable. Illustrating this system, he indicated the pronunciation of the name, "Ohio," would appear as, "Oh-HEYE-OH" in the KFUO simplified key. 2

Station KCMO, Kansas C1ty, Station KTTR, Rolla, Station KHMO, Hannibal, Station KWOS, Jefferson City, and Station KWRE, Warrenton, indicated in the questionnaire that their simplified pronunciation keys are a compromise between the keys recommended by the network guides, the press services, and the dictionaries. Four of these stations use the apostrophe mark to indicate primary accent, but Station KWOS, following along similar lines as those set forth in the simplified keys of the state pronunciation guides, uses no apostrophe for either primary (or secondary) accent. As with the state guides, a keyboard dash line serves to distinguish syllabic groupings.
I Questionna1re, December, 1949.
2 Questionnaire, December, 1949. 
Illustrating full divergence from the simplified keys found in the network and state guides, the KCMO pronunciations are recorded wholly in capital letters, whereas the KHMO place-name key records pronunciations in lower case exclusively. Combining both these extremes, KWRE records its names with the initial letter capitalized, just as the name is normally spelled.

Station KBOA, Kennett, Station WHB, Kansas City, and Station KDMO, Carthage, recorded their questionable names in a key resembling that used by the dictionaries. Vowel sounds are indicated by the conventional diacritical markings usually found in dictionaries, and primary accent is shown by the apostrophe.

The questionnaire is helpful in showing that present simplified pronunciation keys used by Missourl radio men are lacking in both uniformity and clarity to effect the surest, quickest, and most unambiguous pronunciations of difficult names in the station's coverage area for use by the station newscaster or announcer. Without benefit of some central authority to consult as to recording the colloquial pronunciation of a place-name in his station's area, the Missouri radio news editor is likely to become his own authority, right or wrong.

Station KXOK, St. Louis, perhaps expressing the consensus of the seventeen stations which did not reply at all to 
this question, wrote, "we have no established key, but will abide by yours." As if to echo KXOK, Station KSD, St. Louis, put somewhat the same line of thought in the two words, "none special."

Station KTTR, Rolla, had the longest reply to this question, expressed by Luther W. Martin, Radio news editor. He said:

In associating with the natives, we make it a point to concentrate on their pronunciation of the peculiar names with which they are familiar. We then try to set up a phonetic key that will at first glance give us the proper colloquial pronunciation. However, we are not even consistent when the 'native' pronunciation becomes so 'hill-billyish' that we can't bring ourselves to foster the colloquialism. 3

Apparently interpreting the term, "colloquial" to mean "local" or "provincial" rather than "usual" pronunciation as used by educated persons when speaking conversationally, the KTTR phonetic key symbols indicate that the name, Vienna, is pronounced with the long " $i$ " sound in the station's coverage area by the average listener. For the KTTR newscasters and announcers, however, the long " $e$ " of the name is the recommended pronunciation. While the latter pronunciation is more usual throughout the country, the possibility of this pronunciation instantly being recognized by the KTTR listener lessens to the degree

3 Questionnaire, December, 1949. 
the local listener may be familiar with the usual national pronunclation. Since KTTR is a local station serving a local area, the sagacity of such a recommended pronunciation may be questioned in the light of practicability.

Station KWTO, Springfield, while indicating its troublesome place-names in the narrow form of the International Phonetic Alphabet, does not employ the IPA in 1ts newscast scripts. The narrower, or less well-known form of the IPA, is used by scholars many times to indicate unmistakably the pronunciation of the word in question. Th1s system is illustrated in the KWTO indicated pronunciation of the name, Calro. The station lists the pronunciation as "ké'ro," the initial "e" vowel combination representing the same sound as the symbol " $e$ " in the broad form of the IPA.

Station KWOC, Poplar Bluff, Station KGBX Springfield, and Station KFRU, Columbia, recorded their recommended pronunciations in the simplified respelling manner, the same as the system used by the press service radio wires. This is essentially a system which makes use of the letters that comprise the English alphabet, thereby making it unnecessary for the user to learn new symbols in order to approximate the sound of the word in question. While some of the network handbooks and state guides indicate primary accent by capitalization, the press services 
use the apostrophe mark found on all standard typewriter and teletype keyboards since all the press service news copy is sent out in capital letters.

of the remaining questionnaires returned, five stations did not reply to the final page at all. Five stations, while listing their troublesome place-names, did not indicate any phonetic key as used by that station in recommending pronounciations. Some stations listed both names and simplified key, but did not indicate how they happened to select this key nor what equivalent vowel sounds and consonant combinations the symbols were supposed to represent.

In his preface to the NBC Handbook of Pronounciation, Bender cautions that respelling is frequently less reliable than the IPA or the diacritical markings usually found in the dictionaries. This is especially true in regard to the unaccented vowel sound, "schwa," which occurs in words like "lemon," "about," "taken," and "penc11." 4 An example of this respeling weakness, found both in the NBC key and that of Greet in the CBS pronunciation handbook, World Words, is found in the "uh" sound of Bender's key word,

4 James F. Bender, NBC Handbook of Pronunciation (New York: Thomas Y. Crowe II Company, 1943), p. xI1. 
"up," and in Greet's key word, "but." 5 This sound in the simplified key appears to have the same value as the "uh" sound in "sofa, " and "convey," but the finer shade of difference in these sounds is unmistakably clear in the IPA symbol, "A" in Bender's "up," and in the diacritical markIng, "w" over Greet's "but." Bender indicates the final Indeterminate vowel sound, followed by the consonants, " $n$," or " $m$, " by use of the apostrophe mark where Greet uses the "uh" equivalent for this position as well as for the primary and secondary "schwa" sounds in a given place-name. Illustrating this difference in recording the "schwa" sound by Bender and Greet, KGBX indicated the pronunciation of the place-name, Seligman, in the station's key is written, "Suh LIG $m$ ' $n$," the final indeterminate vowel sound being indicated by the apostrophe mark as recommended by Bender. However, this same name would be written as, "Suh-lig-muhn" by Greet. As to which of these two keys is the clearer in indicating the pronunciation, both may be sald to have their merits and either can be referred to with confidence provided the reader is familiar with the key symbols.

5 William Cabell Greet, World Words (New York: Columb1a University Press, 1944), p. 39. 


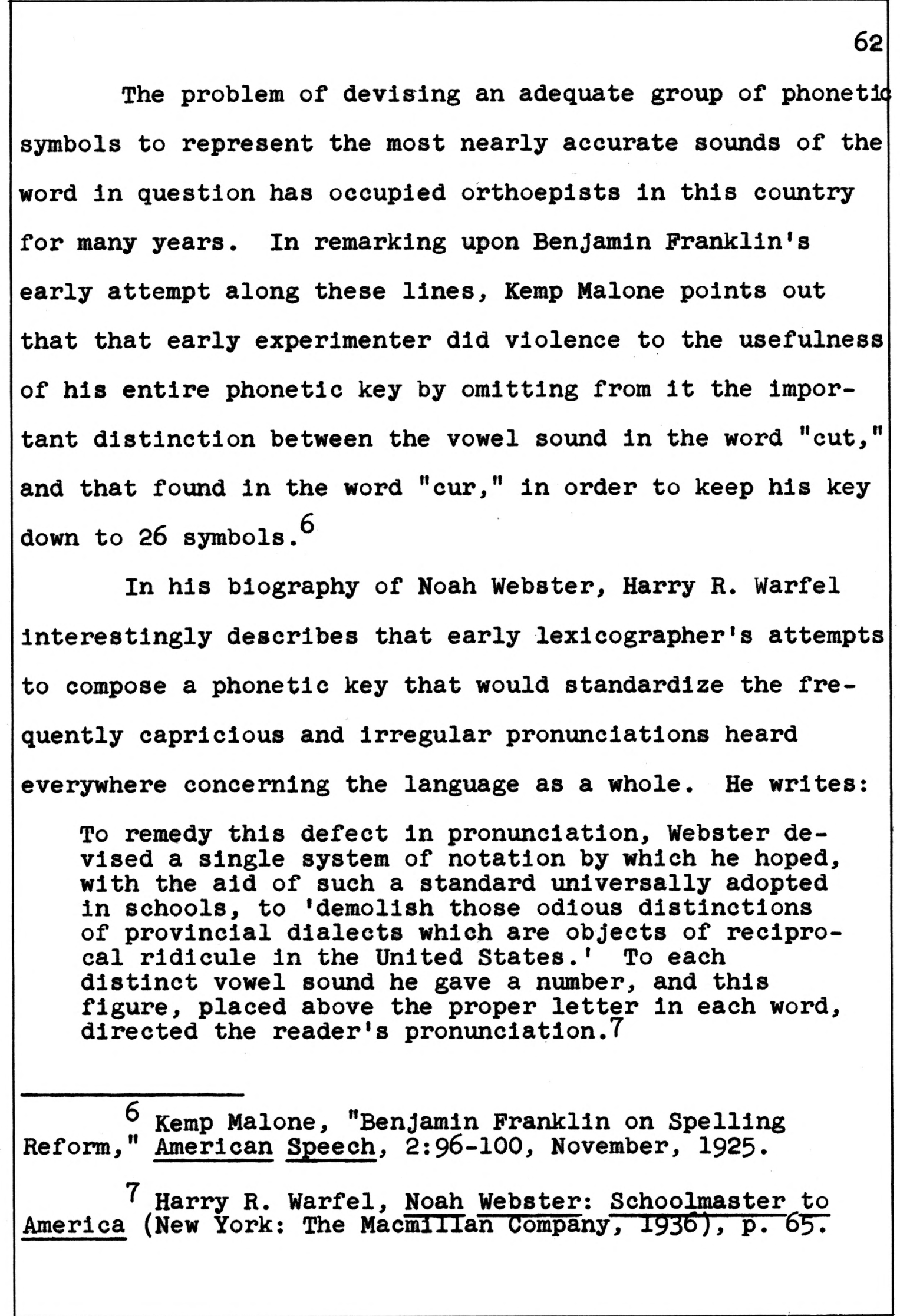


This system of indicating vowel sounds has been carried down to present-day pronunciation authorities by Joseph Thomas in both Lippincott's New Gazetteer and Lippincott's Universal Pronouncing Dictionary of Blography and Mythology. Joseph E. Worcester, a contemporary of Webster and compiler of A Universal and Critical Dictionary of The English Language, did not follow his rival

American's phonetic key to pronunciation when he issued his large work which featured a gazetteer of world place-names in the final section of the work. That Worcester was familiar with Webster's phonetic key is evident since he made an abridgment of Webster's American Dictionary of the English Language while working on his own dictionary, A Comprehensive Pronouncing and Explanatory D1ctionary of the English Language, circa. 1828. Not looking, however, to his fellow American lexicographer for guidance in establishing his own pronunciation key, Worcester looked to Johnson and Walker in England as the basis for his work, revising those compllers' earlier efforts in recording pronunciation, along with the other divisions of etymology, where he thought necessary. In the introductory explanation of his second dictionary which appeared in 1848, Worcester describes his phonetic key by saying:

The system of notation which is here used, while it makes a very exact discrimination of the different sounds of the letters, will be readily understood 
and easily applied to practice; and it will also be much more easily remembered, than a system in which the vowels are marked with figures. ${ }^{8}$

This desire to keep his pronunciation key as simple and as easy to remember as possible did away with the then-current practice of lexicographers of respelling the word, employing the numbered vowel system to indicate the pronunciation. Worcester's system was much the same as that used by most dictionaries today, the word's pronunciation being indicated by a standardized system of diacritical marks placed directly above the word in question instead of the respelled word being placed alongside its original form, a serles of numbered vowels indicating pronunclation. Thomas's pronunciation key as used in the both Lippincott dictionaries is a reproduction of Webster's early key insofar as his numbering the vowel sounds is concerned and in its re-spelling of the word in question. Thomas follows Worcester, however, in indicating the obscure "uh" sound of the untressed vowel, by placing a dot beneath the vowel in question, rather than having a special symbol for this sound, as has the International Phonetic Alphabet, for example. Also emulating Worcester's desire

\footnotetext{
8 Joseph E. Worcester, A Universal and Critical Dictionary of the English Language (Boston: Wilkins, Carter and Company, 1848 ). p. $x$.
} 
to make his phonetic key as simple and as easy to use for the layman as well as the scholar, Thomas writes:

In marking the pronunciation in the present work, our aim has been not to embarrass the reader with unnecessary marks or signs. Thus, in giving the pronunclation of the Italian name, CIARPI, we have simply written, 'char/pee, ' which gives the pronunciation of this name as perfectly as ichár/pé, could do; because in English 'a,' Immediately followed by ' $r$ ' and another consonant, always takes its second, or Italian sound, and 'ee' usually represents the sound of the Italian ' 1 ' quite as well as ' $e$ ' or 'ê' could do. 9

The Lippincott orthoepist, however, cautions against using the same letters in indicating a name's pronunciation, since confusion is likely to arise in the readers' mind if he should be called upon at a later time to render the correct spelling of the name. Thomas points out that although it is safe to indicate the pronunciation of the name, "Mollere," using the respelled form, "Mo-le-air," this system might be harmful if used with a name such as "Beaucaire," in which the pronunclation was respelled, "bo-kair." In the latter instance, the reader might recall only the simplified form of the name and spell the name in that fashion rather than in 1 ts correct form. To guard against this possibility, Thomas indicates the pronunclation of "Beaucaire," by respelling it, "bo-katr," the

9 Joseph Thomas, Universal Pronouncing Dictionary of Blography and Mythology (PhIladeIphia: J.B. Lipplncott Company, 1930$),$ p. 24 . 
second vowel having the sound of " $a$ " in "fare" or " $e$ " in "there," according to the compiler's explanation in the introduction to the dictionaries.

In determining a method of phonetic representation for current dictionaries, gazetteers, and pronouncing handbooks, compllers have abandoned the earlier system of numbering varying vowel sounds within a given key, in favor of three principal systems: (1) the broad form of the International Phonet1c Alphabet; (2) diacritical markings, and (3) simplified respelling of the word, based on 1 ts normal English vowel and consonant sounds. In the most recent pronunciation guides for state broadcasters and networks, a combination of these three systems has been used so far by the networks only, with the state guides indicatIng pronunciations in but one or the other of these systems. Of the five pronunciation guides issued by Iowa, Illinois, South Dakota, Kentucky, and Wisconsin, all but the last record place-name pronunciations in the simplified respeling fashion. In the Wisconsin handbook, pronunciations are indicated by diacritical markings only.

Simplicity and accuracy are necessarily the fundamental cornerstones upon which the compiler must build his pronouncing guide if that guide is to be used to the fullest extent by the largest number of people. Loglcally, then, in determining what method of phonetic representation 
he will use in his guide, the compiler determines as well the scope of his readers to some considerable extent. The symbols of the International Phonetic Association, though well-established in usage by a majority of linguistic scholars throughout the world, are not well-known among the larger components of the literate population, even though these groups may have received a high school or college education. And, the compiler must take into consideration also that even though the IPA symbols may be known by an individual, that person may prefer to read and write anothef system of phonetic representation rather than the IPA. Greet acknowledges this situation when he says:

I use IPA in my courses at the University, but I have never been able to persuade anyone but a student to learn it, simple as it really is. Henry Mencken abominates 1t, and used regularly to try and persuade me to drop it from the magazine, American Speech-claiming that it cost us subscribers.10

Professor Daniel Jones, a British phonetician wellknown for his book, An English Pronouncing Dictionary, explains his reason for using the IPA symbols in his work. He writes:

The phonetic alphabet used is that of the International Phonetic Association. I have adopted this system of transcription not merely because it is more widely used than any other, but because I

10 Letter to the writer, W. Cabell Greet, February $24,1950$. 
consider it the best at present in existence. The simplified 'broad' form of transcription usually employed for practical purposes has been adopted; it is the form which uses the minimum number of symbols consistent with avolding ambiguity.II

In The Broadcast Word, Professor Arthur Iloyd James, pioneer BBC speech consultant in the early days of commercial broadcasting, discusses the pronouncing guide compiler's phonetic representation problem in more detail when he says:

One of the concerns of phoneticians and others for many centuries has been to bridge the chasm between speech and print, to invent systems of writing that more closely approximate the sounds of speech. It is not difficult to write the main languages of the world in such a way that their sounds can be pronounced fairly accurately at sight. An International Phonetic Alphabet exists, designed expressly for this purpose; it is used regularly for the transcription of languages all over the world, and has served as the basis for the recently designed orthography of African languages produced by the International Institute of African Ianguages and Cultures.12

While it is granted that the selection of one of the other three current systems of indicating pronunciation is to some extent an arbitrary matter depending upon the

11 Daniel Jones, An English Pronouncing Dictionary (New York: E. P. Dutton \& Company, Incorporated, 1943), p. 22 .

12 Arthur Lloyd James, The Broadcast Word (London: Paul, Trench, Trubner and Company, Ltd., 1935), pp. 12-13. 
purpose for which the work was intended, it should be the concern of the compiler to have a clear purpose in mind for using one or more of these three systems. The compiler or compilers of a present-day pronouncing gazetteer, usually an integral part of most dictionaries today, have a genuine responsibility to their readers in selecting a system of phonetic representation that will clearly and readily indicate to the layman how each word is pronounced usually by educated persons.

That the editors of one of the nation's foremost dictionaries recognize this limitation in accurately representing a pronunciation, is found in their statement in the Webster's New International Dictionary. They say:

Even when the actual usage to be adopted as a standard is determined upon, only approximation to exactness can be attained in its indication. The sounds which must be indicated by the same symbol are often subject to a considerable variation as spoken, not only by members of different communities, but also, frequently by members of the same commun1ty. 13

In a recent investigation conducted by Professor Jane Dorsey Zimmerman ${ }^{14}$ in comparing actual pronunclations of pre-determined words as spoken over the air by a number

13 Webster's New International Dictionary (Springfield: G.8C. Merriam Co., Publishers, 1925), p. xxxvi11.

14 Jane Dorsey Zimmerman, Radio Pronunciations (New York: Kings Crown Press, 1946), pp. 110-111. 
of American public figures with those recommended in diacritical markings by Webster's Dictionary, she points out that the Websterian system is anything but simple for the untrained dictionary user. By aligning these diacritical markings alongside the IPA symbols, which are now included in the Webster Guide to Pronunciation, Mrs. Zimmerman believes the pronunciation entries could be more easily understood by the uninitiated user. In this respect, her premise is backed by Bender's guide for NBC and that prepared by James for the BBC. Greet, however, prefers to reinforce his CBS simplified key with diacritics alone, whereas Brodie likewise uses this system in his CBC handbook altogether.

The CBS speech consultant explains his position in using diacritical markings and the respelling system, rathef than an alliance of the IPA system and Webstrian diacritics as suggested by Mrs. Zimmerman. He writes that if he had his book to do over again, he would repeat this system, since the newscasters say that therprefer the diacritical markings reinforcing the respellings. Greet points out, however, that the CBS staff has become familiar with these two keys after several years' daily consultations in the course of network newsroom operations. 15

\section{Greet, op. cit., p. 1 .}


71

Canada's Supervisor of Broadcast Ianguage, while indicating agreement with Professor Zimmerman respecting the inclusion of the IPA along with the system of diacritical markings, presents the viewpoint of the Canadian Broadcasting Corporation on this matter. He writes:

I belleve that for the proper indication of pronunciations of this kind the only really satisfactory method is to use the symbols of the International Phonetic Association or some modification thereof. In my own experience I have found that plain transliterations are often ambiguous and occasionally misleading. Unfortunately the I.P.A. symbols are not sufficiently well-known to be really useful and I felt that the use of diacritical marks provided a safe middle-way.16

For indicating pronunciations in the Wisconsin Pronouncing Gazetteer, Harold A. Engel cites the fact that he believes the diacritical markings give the greatest assurance of belng fool-proof for layman use in broadcasting. 17 Conversely, Niel Plummer favored the respeling system entirely because his Kentucky place-name guide was intended to be a working guide to be used often under pressure. 18

Emphasizing the fundamental linguistic proposition that must be understood by the pronunciation guide compiler

16 Letter to the writer, W.H. Brodie, February 20, 1950. $28,1950$.

17 Letter to the writer, Harold A. Engel, February

18 Letter to the writer, Niel Plummer, February 14, 1950. 
and user before the one can fully appreciate the position of the other, Mrs. Zimmerman says:

The IPA alphabet is the best graphic system devised to date for recording the pronunclation, not only of English, but of many other languages. But it must be admitted that even with this system it is not possible to teach the sounds of English, or any other language, by visual means only. It is necessary for one who speaks the language to know the acoustical patterns of the sounds, and to be able to interpret them in terms of the symbols.19

Since, in compliling a guide for local broadcasters It is reasonable to assume that these acoustical patterns have been known to the newscaster or announcer since childhood, the major concern for the compiler, then, centers in his representing these sounds with absolute clarity and lack of ambiguity on the one hand, and simplicity and speedy usefulness on the other. Arthur M. Barnes, compller of the Iowa guide, recognizing this consideration, points out that the International Phonetic Alphabet represents the extreme on one side, while the use of no special symbols represents the other. In determining the Iowa key, Barnes selected his symbols and their English sound equivalents from the systems used by the press services, Time magazine, the IPA, and the CBS and NBC handbooks. 20

19 Zimmerman, op. cit., p. 112. $7,1949$.

20 Letter to the writer, Arthur M. Barnes, October 
That this realization of the limitations of any sort of phonetic key came earlier to the BBC speech consultant, Lloyd James, is readily perceived in his remarks on this point early in his book. James points out that even with all the devices and resources at the disposal of musicians for indicating the interpretation of a given passage, no two artists will interpret that passage al1ke. LIkewise, James notes, no phonetic system of symbols will solve all the problems in trying to represent visually phenomena that have no visual existence. 21

Perhaps stepping too far aside in his recognition of the weaknesses of all phonetic keys, Holt is demonstrably enthusiastic when he indicates his desire to foresake completely diacritical markings in his guide. He does admit, however, that it was necessary to use accent marks and a number of dotted " $a$ 's" and " $e$ 's" to represent the symbol, "schwa." He adds that wherever feasible, accent is indicated by italics, while the increasingly popular "rhymes with" system usually indicates the colloquial pronunciation. 22

21 James, op. cit., pp. 16-17.

22 Alfred H. Holt, American Place Names (New York: Thomas Y. Crowel1. Company, 1938), pp. 9-10. 
It is interesting to note that although the majority of Missourl stations indicated using the respeling system for their troublesome pronunciations, none indicated use of the "rhymes with" system, now frequently used by the press services to clarify an especially difficult pronunciation. This system is used occasionally also by the CBC in 1ts handbook w1th good affect.

While such important considerations as the teletype and typewriter keyboards, amount of space in the copy, and the lack of a standardized phonetic key system necessarily impose physical limitations on the clarity and reliability of locally-produced place-name pronunclations, this situation has been eliminated mostly by the press services on the national scene.

Describing her organization's early efforts to solve this standardization problem, Lizbeth Straus of the United Press writes:

Our method of phoneticizing is dictated largely by the limitations of the teletype which has no diacritical marks on the keyboard. We adopted some years ago a standard representation of vowel and consonant sounds such as ' $1 \mathrm{gh}$ ' to represent long ' 1 ', ' 1 ' to represent short ' 1 ', 'ee' to represent Latin long ' 1 ' as in machine, ' $a$ ' to represent short ' $a$ ', 'ay' to represent long ' $a$ ', etc. 23

23 Letter to the writer, (Mrs.) Lizbeth Straus, assistant to Ph1l Newsom, November 9, 1949. 
Emphasizing his service's full-time concern in New York in teletyping a troublesome name to its clients, the Assoclated Press radio news editor says, "The Important thing in phonetics is clarity. They must leave no doubt as to the sound and accent intended." 24

In comparing the International News Service daily pronunciation guide, Say It Right, with those issued every day by the Associated Press and United Press radio divisions, it is readily apparent that INS uses the same simplified respelling key as the other two services. An important distinction is seen, however, in the added qual1fications for each name supplied in the INS guide. Thus, the INS client not only recelves an authoritative pronunciation for each of the day's difficult names in the news, but he also recelves a brief, but adequate identification of that person or place in addition.

Interestingly enough, the nation's fourth major radio news service, Transradio Press Service, issues no dally pronunciation guide, as such, to its clients. The oldest radio news service still in operation, Transradio has a distinctive policy with respect to transmitting difficult pronunciations. The New York editor writes: 1950.

24 Letter to the writer, Tom 0'Ne1l, January 17, 
Transradio Press has no fixed pronunciation guide, or key. Since news is a fluid commodity, the problem is dealt with as 1 t arises. . the first time it comes up, and thereafter until it can be assumed that the newscaster has become familar with the pronunciation. We feel that giving the 'how to say 1t' in the body of the story is more useful to the newscaster than would be a listing run at a later time (possibly past the news hour), or at the bottom of the story, where his eye must make a quick jump down and up again if he needs a refresher at the microphone.25

Transradio's respelling system, however, is the same as that used by its sister services. Although perhaps somewhat individualistic in the manner in which its pro-nunciations are dispatched to its wholly radio station clientele, this press service must comply with the limitations of the mechanfcal keyboard the same as the others. Recognizing this fact, the Transradio editor says:

Admittedly, there is difficulty in getting a correct pronunciation across the limitations imposed by a teletype keyboard. Phonetic symbols, of course, cannot be used. Therefore an approximation must sometimes be necessary. An example was the former French prime minister, Dr. Henri Queuille. We wrote (kuh-ee'-yuh) and let it go at that, repeating the teletype phoneticism in succeeding stories until we felt sure that it had been mastered.26

Supporting this contention, the Associated Press editor cites the fact that although two recent Webster

25 Letter to the writer, Richard Wilson, February 10, 1950.

$$
26 \text { Ibid., p. } 2 .
$$


dictionaries, a gazetteer and a biographical dictionary give reliable pronuncations, these are indicated by diacritical markings which are impossible to transmit by teletype. 27

One important consideration which has yet to be met fully by state pronunciation guide compllers, as well as the authors of the network handbooks, concerns their agreeing upon a standardized system of phonetic representation. Although this lack of uniformity may be helpful to the layman in consulting the network handbooks in that he is given a choice as to which system he can use, this individuality on the part of the state compilers is more than likely to cause some suspicion and perhaps even to confuse the newscaster or announcer who has occasion to make use of several different state guides during the course of a day. When consulting the NBC or CBS handbooks for elther an international, national, or local place-name pronunciation, the radio man cannot help but recognize the weight of national authority backing that recommended pronunciation, or pronunclations. Whether, as in the case of the NBC handbook, a combination of diacritics, respelling, and the IPA are used to indicate pronunciation, or whether, as in the CBS guide, only the diacritics and respelling are used, the

27 Letter to the writer, Tom 0'Ne11, February 13, 1950. 
user, after daily consultations for a short period, soon learns to quickly recognize any given pronunciation. If, on the other hand, a number of noticeably different phoneti\& keys are thrust upon the unwary newscaster by state compilers of limited reputation in the field of phonetics, the radio news man is apt to cast a critical eye upon the local authority and continue consulting his accustomed authority. Thus, instead of supplementing his national network handbook pronunciation recommendations with those offered in the local guide, the newscaster or announcer is likely to pit the one against the other, choosing the network guide alone in the final analysis.

As the number of state guides has increased in the past few years, a growing awareness on the part of radio news directors concerning this situation has developed. Since, in many stations, more than one ste guide is necessary to adequately take care of the station's overlapping coverage area into other nelghboring states, these guides should be accorded the same recognition by their intended users as those of the networks if they are to meet the needs for which they were designed. A standardized key of simplified phonetic symbols for the state guides w111 be a mor step in this direction.

Appreciating this situation after years of radio experience, Henneke cites the important fact that the use- 
fulness of any phonetic key depends, in the final analysis, upon agreement of understanding between the newscaster and the sounds in the key words which are used as examples. If the newscaster or announcer is unsure of the pronunciations of the key words, then the usefulness of the guide is terminated automatically. Henneke refers to the respelling system as an agreement between the complier and the user that certain spellings always have the same sounds. That this beforehand agreement is essential to the newscaster if he is to understand accurately the recommendations made in a particular guide, is the point of Henneke's argument here. He explains:

One system of respelling transcribes the word 'care' as 'kehr'; another transcribes it as 'kair,' another, simply as 'kare.' If the announcer can understand the particular system of respelling used in one book he is completely lost with another book until he has learned the different system used in it.28

Agreeing with Bender and Greet that the IPA is relatively simple for the layman to learn, Henneke adds that this international phonetic key likewise eliminates the ambiguities of spelling, and diacritical markings and the inaccuracies of respelling. And, in concert with Bender, he points out that the IPA 1s being utilized more and more within the radio industry as well as in nearly all

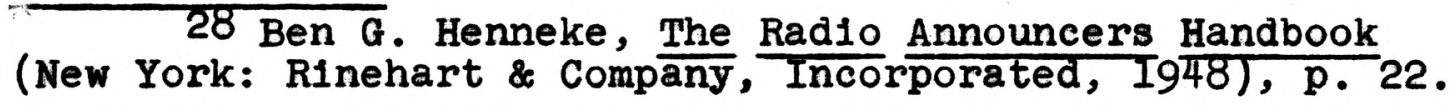


college forelgn-language courses and in many speech courses in vowel and consonant drill.

Illustrating h1s thesis that the guide key cannot be all things to all users where the slightest doubt exists as to the English sound equivalents represented by each symbol, Henneke mentions the newscaster who pronounced "menu" as "men-oo," as a result of his misinterpreting the sound of the given key word.

In citing the importance this problem is assuming within the membership of the National Association of Radio News Directors, Barnes writes:

The National Association of Radio News Directors is greatly interested in these projects. One of the points I have been trying to make with the other members of the committee is the need for a standardized system of symbols. Guides to all the states in the Union would be useful to the networks; most stations are interested in other states besides their own. But 10 different ste guides using 10 different systems of representing speech sounds won't be as helpful as they ought to be.29

Attempting to ascertain the current variances in recommended pronunciations as offered by the four radio press associations, the Association recently drew up a questionnaire in which this matter was ranked along with such other important categories as writing, timeliness, news judgment and coverage, and varlety of news types. The

29 Barnes, op. c1t., p. 1. 
question dealing with pronunciation asked, "To what degree do the press associations vary in their recommended pronunciations?" The study was begun with a survey of all copy filed by AP, UP, INS, and Transradio between March 6 and 12, 1949. The object of this investigation was to find out the shortcomings of the wire services, where they may have fallen down on the Job, and in what ways, if any, they were slighting radio news departments. The Association believes this survey provides the first concrete report on wire service coverage made available to the radio news industry. 30 While the services' key symbols bear close affinity to each other, as has been discussed earlier, which helps eliminate the possibility of frequent faulty interpretation by the newscaster, this concern over variant pronunciations by the NARND 1llustrates the Industry's increasing interest in orthoepy as a whole. It is interesting to note that whereas in England and Canada the wire services' recommended pronunclations can be drawn readily from the $B B C$ and $C B C$ guides as the official authorities, the press associations in this country have no single guide which they consult as "the" authority. As a consequence, each association has established its own

30 "NARND Maps Extensive Survey of Wire Service News Coverage," The INS Newscaster, 4:3, March-Apr11, 1949. 
authorities in recommending pronunciation as well as in determining the phonetic symbols to be used by that association on its radio wire.

With the formation of the Associated Press radio division, Press Association, Inc., in 1941, the need for a pronunciation guide for use by broadcasters who had daily cause to refer to many foreign place-names then prominent in the news was apparent. Not only were the wire services' clients at a loss as to what authority should be consulted for most of these pronunclations, but the networks also lacked the full-time services of their consultants in that year in issuing the official handbooks which appeared a few years later.

Realizing that time plays a vital part in assembling an adequately prepared newscast, Press Association secured the services of a noted Dutch philologist and linguist, Jules Van Item, to formulate a key of vowel sounds and consonant combinations which henceforth would represent the official Associated Press simplified phonetic key. In explaining the composition of his key, the compiler writes:

Ordinary gazetteer pronunciations are not practical enough for the speed required in getting the news on the air. The umlauts and accent marks can be confusing even when time isn't a problem. So, I've worked out my own system of strictly phonetic spelling, dispensing with all the confusing dictionary symbols. It is along the standard principles of English. 
pronunciation and, inasmuch as the broadcasts are for English-speaking people, the results are intelligible and acceptable without appearing forced. 31

For the practical considerations already discussed, the Press Association guide key limits itself in the number of symbols representing the different English vowel sounds. Since the guide deals wholly with foreign place-names, in addition to the names of forelgn personalities and newspapers, the compller has included the symbol, " $\mathrm{kh}$ " to represent the guttural sound found principally in the Germap tongue. Otherwise, the key symbols serve to fulfill their purpose in giving the American newscaster a close approximation of the foreign, or in this instance, colloquial pronunciation. Where any possibility of mis-interpretation could exist, the compller has resorted to the now-popular system of rhyming the sound with its generally recognized English equivalent. Capitalization, as in some of the network and state guides today, indicates the accented syllable.

During the war, in an effort to aid broadcasters in pronouncing foreign place-names, the United States Board on Geographic Names issued a pronunciation key which, in its effort to render the finer distinctions among the vowel

31 Jules Van Item, PA Pronouncer (New York: Press Association, Inc., 1941), $\frac{\text { p. }}{1 .}$ 
sounds and dipthongs, appears somewhat complicated to the unfamiliar user. Offering as many as ten variations for the vowel sound, "o," the government key burdens the hurried newscaster with phonetic nicety which, while of interest to the scholar, is apt to confuse and discourage the newsman. An additional handicap of this key is found in its manner of syllable separation. Using the keyboard period mark to distinguish the separation of syllables, the representation might readily confuse a reader, especially when this form is inserted in the body of a news report. To the announcer, the perlod mark could mean that automatic inflection of volce was needed as when this mark is placed at the end of a sentence. Without his having read the copy beforehand, this system of syllabication could cause some embarrassment for the newscaster and the station alike.

In addition to the importance foreign names have assumed in the newscast, the Handbook for Announcers points out that they assume prominence also on musical programs. Concerning the pronunciation of both foreign place-names and proper names, the compller says that announcers cannot be expected to, and should not pronounce words from another language exactly as they would be pronounced by a native of that place. This, it is stated, is because the interjection of a precisely articulated foreign word into 
the middle of an English sentence not only requires a difficult effort of oral agility, but also comes as something of a shock to the listener. 32

This contention is applicable not only to network standards, but also applies to local station pronunclation standards with such Missouri place-names as Paris, Versallles, Madrid, Warsaw, and St. Louis. Again stressing the need for a phonetic key which indicates the usual English manner of pronouncing forelgn names readily and accurately, the Canadian handbook says, "In handling names in the news, it must always be remembered that the chief object of an announcer is to make the name recognizable to the general public." 33

Charnley cites an excellent example of how not to indicate the usual English pronunclation of an originally foreign place-name in his description of one press service editor's theory on the name Joliet in Illinols. Apparently unfamiliar with the name's usual pronunciation in that state, the editor recorded the pronunciation as HO-LEE-AYE,

32 W. H. Brodie, Handbook for Announcers (Toronto: The Canadian Broadcasting Corporation, 1946), p. 23.

33 Ibid., p. 24. 
the native French pronunciation. 34 one can only speculate as to how this obvious error was recelved in that locale and other Illinois communities.

Another author of a radio journalism text points out that wherever possible, the radio news editor should avold using a difficult forelgn place-name in his cast entirely. He adds, however, that there will be times when some fawbreaking name may be essentlal to the story. Then, he says, a real service can be done the announcer by giving him a phonetic guide. Interestingly enough, this author bolls the whole problem of phonetic spelling down to a few generalized statements which tend to oversimplify somewhat the entire thesis of this investigation. He writes:

Phonetic spelling is simply spelling out each syllable as it sounds, with a hyphen between, and placing accent marks where any emphasis should go. Pronunciation word books and the dictionary are your guides in radio. Where local names are concerned, you can make up your own. For example: Pidrman (Pead'-er-man). Phonetic spellings can be a great help in new words which have more than one pronunciation. 35

While obviously giving secondary attention to phonetic key representations or the matter of indicating reliable pronunclations in general, this author represents,

34 Mitchell v. Charnley, News by Radio (New York: The Macmillan Company, 1948), p. 114.

35 Burton L. Hotaling, A Manual of Radio News

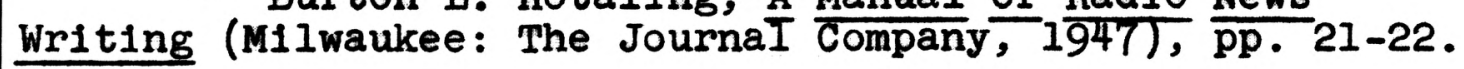


sadly enough, the average radio man's complete faith in a system of phonetic equivalents that are often as variable as the mercury in a thermometer. This apparent indifferent approach to indicating pronunciations on the local level is one important reason for having a standardization of phonetic representation on a national scale.

Conversely, Greet recognizes the weaknesses in any such system as that recommended by Hotaling when he writes that his pronunciations are always indicated by the use of two keys in the hope that the one may identify the other for readers who consult in haste and are not accustomed to one or the other key given. Since, for reasons left unstated, the CBS speech consultant does not employ the International Phonetic Alphabet symbols in any of his three pronunciation handbooks, he laments the fact that, in this first work, the broad form of the IPA was not used. He remarks further that, "The ideal dictionary would probably employ IPA in a key for the learned and a simple respelling according to English conventions in a key for the unlearned and fearful." 36

of interest today in indicating how the local placename pronunclation problem was handled on the local level

36 w. Cabell Greet, War Words (New York: Columbia University Press, 1943), p. 5 . 
10 years ago, is the observation made by the author of an early text on radio news. He says:

The practice of providing phonetic spelings for the announcer is not generally followed in radio news offices today, although it is a valuable aid to announcers. In practice, the editor compiles a list of such spellings, especially for foreign names, the pronunciation of which is not known or not established. In this manner a station can obtain uniformity in the use of these words. Nothing sounds much worse than two announcers on the same station pronouncing the same word differently, or one announcer pronouncing the same word two different ways in the same newscast. 37

In establishing the key symbols for the Missouri guide, a primary objective was the eradication of such ambiguity whenever a difficult Missouri place-name appears in a newscast. Three distinct types of phonetic representation were considered for inclusion in the guide. These were the International Phonetic Alphabet, diacritical markings, and the respellingsystem, using the English alphabet. While the IPA is the most unequivocal of the three systems, it is also the least known generally. The fact, however, that this system is being taught increasingIy in the speech departments of many universities and colleges would tend to indicate that its value as a popular tool of pronunciation has not been overlooked.

37 Paul H. Wagner, Radio Journalism (Minneapolis: Burgess Publishing Company, 1940), p. 101. 
Diacritical markings, while in wider favor than the IPA, have an important weakness with respect to standardiza tion since at present a number of keys are in current use which differ, one from the other, in a number of important respects. Discussing this lack of unity in the diacritical markings, the dictionary editors write:

The earlier lexicographers resorted to diacritical marks--dots, curves, numbers, or other signs--placed over and under the letter; and this method is still largely in use. But 1 it is unsatisfactory because so many marks are required. - . There must be a mark to show when a letter is silent, a mark to show whether a vowel is long or short; and there must be accentmarks. And so 1t will of ten happen that the same letter must have two or three diacritics.38

Pointing out that in addition to offending the eye, diacritics make trouble for the writer, printer, and proofreader, the editors conclude that the marks leave the user, just as in the ordinary orthography, with many different symbols for the same sound. Emphasizing the important principal in the composition of the phonetic key, the editors cite the fact that representing two or more sounds by the same symbol may mislead the reader. This, they point out, is a far more serious matter than using two or more letters to indicate the same sound in the key.

38 Funk and Wagnalls, New Standard Dictionary of the English Language (New York: Funk \& WagnaIls Company, 1939), p. XX111. 


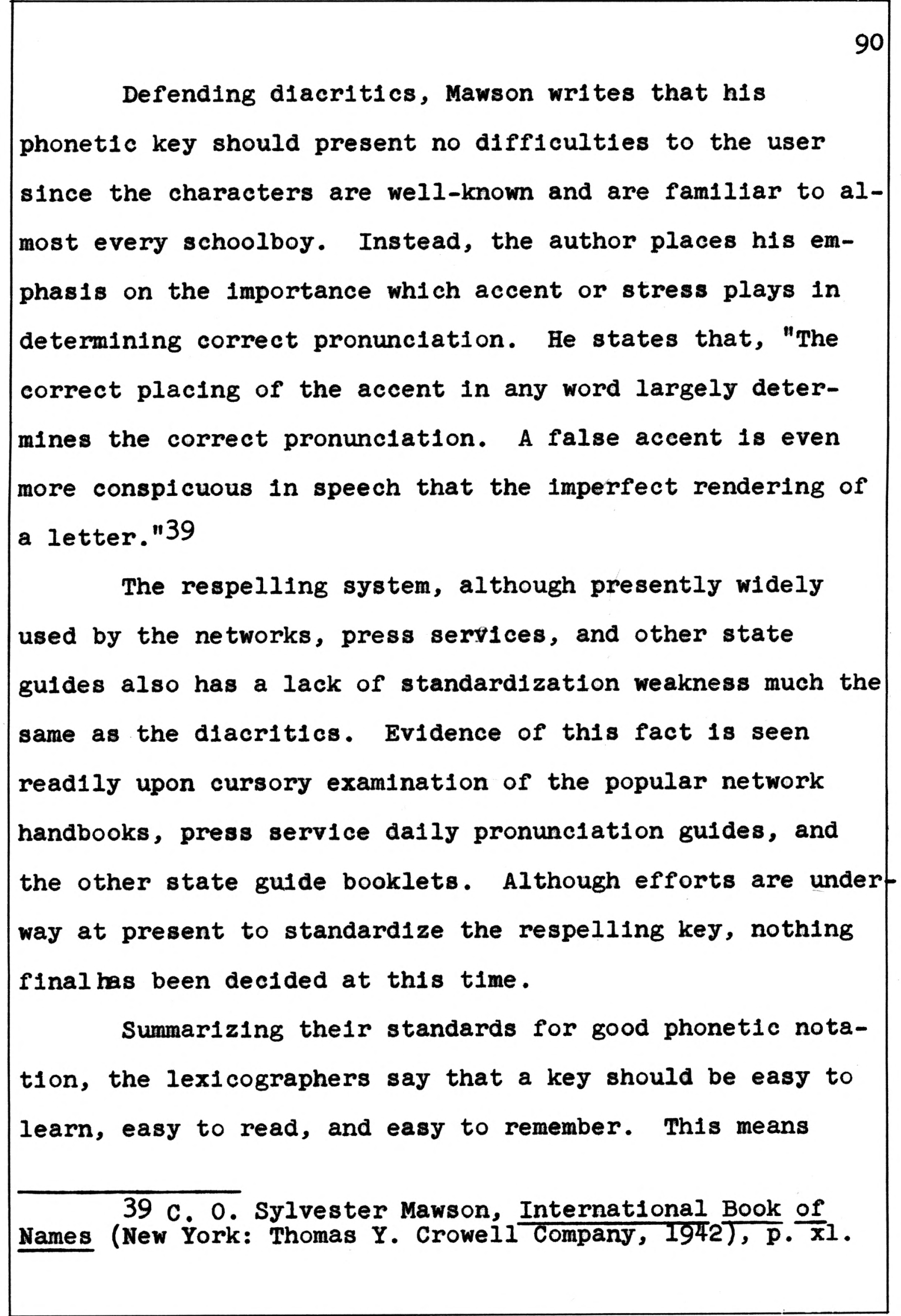


they point out, that Roman letters are preferable to analphabetic characters and that there should be no mixture of roman and 1tallc forms in the same key. 40

In selecting and arranging the place-names in the Missouri guide, an arbitrary decision was made to include all names which might ordinarily offer some pronunciation problem to the average speaker. These names include not only those of foreign origin, indicated by the spelling in most cases, but also many Anglo-Saxon names which in this state are pronounced in a distinctive fashion. Such names, however, as Bell C1ty, Black, Grayridge, Green City, Hilldale, and Wilson are not included in the gute because those names incorporate fundamental English speech sounds which are ordinarily recognized at once by anyone familiar with the English language. Since the predominant number of Missourl place-names fall in this category, the guide must be regarded as necessarlly selective in its inclusion. Attention has been paid, however, to those names which could offer a chance of pronunciation error for orthographical reasons. In recognizing the care which must be taken by an authority in attempting to guide the user around these spelling pronunciation pitfalls, the dictionary editors remark that it is unfortunate that pronunciation

40 Funk and Wagnalls, op. c1t., p. xxiv. 
cannot be shown exactly by means of the English alphabet as ordinarily employed, but such is the fact. They point out that this is because we are in the habit of denoting different sounds by the same letter and the same sound by different letters. 41

As in the majority of other state guides, each Missouri place-name is listed alphabetically, with the county or counties in which that place is located, indicated alongside. Unlike the other state guides, however, the Missouri guide acknowledges the fact that in a number of instances variant pronunciations do exist with equal validity throughout the state and should be recognized and recommended in a guide such as this.

Where this situation has been found, both pronunciations are listed side by side in the hope that the user wilf feel free to select one or the other or both with equal confidence. Realizing that in several instances one pronunclation may be favored over the other in the local community, the guide leaves the final selection entirely up to the reader.

The pronunciations of city, town, village, county, and river names are listed alphabetically in the same list. Again, the Missouri guide differs from the other state guides in this respect since they list county and river

\section{Ib1d., D. $x \times 111$.}


names separately in most cases. It is felt, however, that the compilation adopted follows the arrangement of most of the prominent dictionaries in this matter.

Likewise, the pronunciations of nelghboring state names are listed in the general listing. It is felt these inclusions serve a necessary purpose since a number of Missouri radio stations broadcast across state boundaries. In the thesis where no letter is placed alongside the recommended pronunciation, this indicates the source for that pronunciation was one or several of the eighteen Master's theses on Missouri place-names completed in the Department of English under the supervision of Dr. Robert L. Ramsay, national authority on Missouri place-name pronunciation.

For purposes of simplification, all other sources of the recommended pronunclations have been grouped under thre alphabetical letters. These are the letters $K, H$, and $Q$. Wherever the letter $(K)$ is listed alongside a pronunciation the source was A Pronouncing Dictionary of American English, by John S. Kenyon and Thomas A. Knott, international orthoepic scholars. Wherever the letter (H) is found, this indicates the pronunciation was recommended by Alfred H. Holt in his book, American Place Names, the contents of which are based on an extensive cross-country automobile trip taken by the author for the purpose of 
gathering, first-hand, the usual pronunciations of the places visited. Holt includes a considerable number of Missouri names in this work. Wherever the letter (Q) is found alongside a pronunciation, this indicates the authority was: (1) a respondent to the questionnaire sent to every Missouri radio station in December, 1949; (2) a county superintendent of schools to whom a post card was sent for final verification when a pronunciation was e1ther amb1guous or unknown; (3) a University student who is a resident of either the place itself or of the county in which that place is located, or (4) that the pronunclation is known personally by the compiler.

The two keys found in the thesis and guide are the International Phonetic Alphabet symbols as recommended by A Pronouncing Dictionary of American English by Kenyon and Knott, 42 and a simplified respelling system, based on those found in the network handbooks, press service daily guides, and a majority of the other state guide booklets. It is felt that by including both keys in the thesis and booklet, the Missouri guide attempts to satisfy the needs of scholar and layman alike with respect to each pronunciation herein recommended. \begin{aligned} \hline 42 John S. Kenyon and Thomas A. Knott (A Pronouncing \\ Dictionary of American English, 1944), p. xvi1. \end{aligned} 


\section{CHAPTER V}

COMMENTS ON THE CORRESPONDENCE

In an effort to find out other state guide compilers' progress in preparing guides similar to that for Missouri, and in an attempt to learn other interested persons' needs and desires with respect to the proposed inclusions in the Missouri guide, approximately fifty letters were sent by the writer during the course of this investigation to (1) radio personnel within and outside of Missour1, (2) authors of the pronunciation works included in this study, (3) important public figures in national and state government, and (4) other state guide compilers who have either completed or are occupied presently in completIng guide booklets for a limited number of other states.

Since a considerable amount of this correspondence reflects in no small measure the valid suggestions, inspirations, and wishes of the broadcasting industry and interested persons made during the period in which work was being done on this project, it is felt these remarks have a necessary and deserved place in the thesis. While it must be acknowledged that not all the replies received were helpful toward completing this study, enough such responses were of great enough value to play an important part in the over-all investigation. 
Excerpts from a number of these letters have been included already in other parts of this work when these inclusions were necessary to strengthen a particular point made. Remaining portions of this correspondence are included in this chapter when appropriate to the discussion at hand.

The correspondence herein was begun almost immediate ly after the Missouri place-name project was suggested to the writer in August, 1949. At the suggestion of Edward C. Lambert, Head of the Radio Journalism Department, University of Missouri, a preliminary Inquiry was made to find out what efforts had been made already by radio news and newspaper staffs in Missouri toward compiling their own place-name pronunciation guides for local names. Initial inquiries were sent to Bruce Barrington, Director of News, Station KXOK, St. Louis, and to Harry J. Kaufmann, Program Director, Station WDAF, Kansas City. Letters were sent to these stations at the start because both are important units in the state's present broadcasting station line-up and because for the past several years both stations have indicated a sincere interest in seeing such a project as this undertaken.

The KXOK news director demonstrated his enthusiasm for such an undertaking when he wrote: 
Thank you very much for your letter regarding the project on pronunciation. I am delighted that you are interested, for I feel 1 it is a worthwhile study. - . Generally speaking I have in mind a project something like that which the University of Illinols did for that state. This consists merely of a listing of the towns, their county location and a phonetic pronunciation. 1

Following up this written response several weeks later, the writer had the opportunity of further discussing the contemplated undertaking with that news director in St. Louis. From this discussion, the first ideas were gathered as to the specific needs of the industry in a work of this kind.

The reply from the WDAF program director also proved helpful in developing further a clearer picture of the actual needs of the industry with respect to a Missouri place-name pronunciation guide. He replied in part:

WDAF or NBC, as far as we know, has not done any research work in regard to names of Missouri cities recently. The Associated Press used to send out a daily guide for pronunciation of unusual names, especially during the war. Whenever a name bobs up that we are not familiar with, we do try to run down all authority on same. However, recently we have not found it necessary. I do believe a guide on the subject can always be used.2

At the suggestion of the WDAF program director to 1949.

1 Letter to the writer, Bruce Barrington, August 16, 1949.

2 Letter to the writer, Harry J. Kaufmann, August 26, 
investigate further into the matter of local efforts to compile and recommend Missouri place-name pronunciations, the writer sent letters to the Associated Press bureaus in St. Louis and Kansas C1ty. The St. Louis AP correspondent, Tom Yarbrough wrote, "We have no guide to pronunciation of M1ssourl place-names, and so I am sorry to say I can't help you in your project." 3 His colleague in Kansas C1ty, answering in greater length, said:

You seem to have undertaken a worthwhile assignment and I wish we could help you, but strange as it may appear, we do not have a Missouri pronunciation guide. our radio service provides a pronunciation list from time to time of odd names that pop up in the news reports, but we don't have anything on Missquri placenames. I wish we could do better by you. 4

Under the assumption that the local United Press bureaus probably handled Missouri place-name pronunciations in much the same manner as the Associated Press, requests for information concerning this matter were not sent these agencies at this time. Correspondence was carried on at a later date with UP major outlets in Chicago and New York, the substance of which has been discussed in the preceding chapter.

1949.

3 Letter to the writer, Tom Yarbrough, October 10, 1949.

4 Letter to the writer, Frank G. Gorrie, October 11, 
Going next beyond the boundaries of this state for information concerning Missouri place-names which might be included in the reference files of a national pronunciation authority, a request was sent to James F. Bender, compiler of the NBC Handbook of Pronunclation. This authority, replying promptly, wrote:

Congratulations to Professor Lambert on sponsoring such useful studies. I am glad to know that you are interested in pronunciation problems. To answer your inquiry, may I say that the only data I have on Missouri place-names comes from American Speech, Dialectal Notes, and personal experience as the result of having ilved in St. Louis.5

Although the sources referred to by this respondent are adequate for investigating those names which present specific problems for scholars of orthoepy, they prove of limited use for more all-inclusive information such as was desired in this instance. A similar request sent to the CBS compiler, William Cabell Greet, brought forth no reply until nearly six months later following three additional such inquiries. At approximately this time, a response was received from the Mutual Broadcasting System headquarters in New York City with respect to an inquiry concerning that network's usual authority for verifying Missouri place-name pronunciations and those of other states. Writing a brief, but informative answer, the MBS director of news said: 1949.

5 Letter to the writer, James F. Bender, October 18, 
Mutual uses Webster's Unabridged Dictionary as its final source of pronunciation. To my knowledge it has the most comprehensive, most authoritative list of place-names. . . extant and extinct. I have seen the Iowa Gazetteer and thought it a fine job. I am sure there should be a place for yours. 6

It is probably safe to assume from this reply that this network, like its national counterparts, ABC, CBS, and NBC, has made, up to now, little direct effort to personally verify difficult Missouri place-names either because a more thorough verification was deemed unnecessary in view of the limited number of listeners throughout the country who might recognize an aired mispronunciation, or because no central authority was available for such verifications, even if such thoroughness were desired at a network headquarters in New York City, Chicago, or Hollywood, The MBS director's final remark of those quoted would tend to bear out this latter contention at least. An additional pat of encouragement arriving from the East at this time was recelved from Tom $0^{\prime N} \mathrm{Ne} 11$, Associated Press radio news editor in New York C1ty. Th1s bureau chief remarked:

All success to your Missouri pronunciation guide. The more such books there are the better. Local familiarity with local names and research through university prestige should make such a work excellent. Place-names are familiar close to home; distant places need indications of the sound. For American 1949.

Letter to the writer, Milton Burgh, November 8, 
place-names we rely on gazetteers and local contacts when the books are inadequate. No one book ever is extensive enough.7

Comments from local station authorities at this time include this "boost" offered by the assistant program director of Station KWTO, Springfield, who said, "I would like to commend you for making this survey as I think it's an excellent 1dea, and will be valuable to all Missourl radio stations." 8 Likewise, Lindley Hines, on the news staff at Station KMOX, St. Louis wrote, "I hope you will have a lot of success with this project, for I still feel a guide of this kind will be of benefit to many organizations in Missouri and elsewhere."9 Ed Johnson, program director at Station KFSB, Joplin, writing perhaps in a more pessimistic style than other respondents, remarked, "My condolences and best wishes on your undertaking."10

A second more somber note was interjected into the generally high tenor of replies when Lillian H. Alfred, secretary to Frank 0 . Colby, nationally known writer of a syndicated newspaper feature dedicated to better speech,

\footnotetext{
7 Letter to the writer, Tom 0'Ne11, November 9, 1949. 1949.

8 Letter to the writer, Joe Slattery, November 8 , 1949.

9 Letter to the writer, Lindley Hines, November 9, 1949.

10 Letter to the writer, Ed Johnson, November 9,
} 
wrote, "I am sorry, but Mr. Colby has nothing prepared on Missouri place-names. From time to time he does discuss place-names which are of general interest, but he has never classified them, or picked any particular state." this stage of the investigation it was becoming apparent rapidly that both local and national place-name authorities had little direct information on Missouri place-name pronunciation in centralized, readily accessible form. New attempts were made, therefore, in the weeks and months following to divide and subdivide inquiries into smaller and more distinct categories concerning particular problems arising in the course of conducting the investigation of place-name pronunciations in this ste. Th1s process in the correspondence was slow and often discouraging. Often detalled inquiries met with brlef, perfunctory replies, too inadequate to afford a competent evaluation of possible solutions to the problems at hand. At other times, although the responses were of sufficient length, the material included proved of mediocre value to this study. However, in order to maintain a chronological record of much of this information as it was received, both the valuable and not-so-valuable replies are included in this chapter. 10, 1949.

11 Letter to the writer, Frank 0. Colby, November 
Perhaps one of the most interesting phases of this correspondence was that carried on with President Harry S. Truman and Governor Forrest Sm1th of Missouri. Requests were sent to these high officials' offices in an effort to learn how two of the state's most distinguished citizens usually pronounce the state name. While it is conceded readily that neither official is an accomplished philologist, it was felt that whatever method each used in indicat ing how he pronounced "Missouri" would be of some value toward settling this long-time controversy within and outside the state. Replying to this inquiry in behalf of Mr. Truman, Charles G. Ross, Secretary to the President and one-time member of the faculty at the School of Journalism, University of Missour1, said, "The President pronounces "Missour1" as if it were spelled Miz-zoo-ri ( 1 as in 'In')."12 Interestingly enough, this particular pronunciation is found nowhere in the lengthy discussion devoted to this matter by Dr. Allen Walker Read in American Speech a number of years ago. The closest approach to this form found in this full-length review of the entire problem of how to correctly pronounce the state name is that offered by Colonel William F. Switzler, one of Missouri's most erudite historians, who, writes $\mathrm{Dr}$. Read, pronounces the 3,1950

12 Letter to the writer, Charles G. Ross, January 
name Miz-zoo-rah. ${ }^{13}$ This pronunciation, popularly effected by many native sons at the turn of the century, has not yet been accorded official recognition in the gazetteer in Webster's New International Dictionary, the 1940 edition. This authority agrees with the phonetic representation submitted by the White House in all but the inftial " $z$ " sound and in the location of the final "r." In this respect, the correspondence received from the state's present Chief Executive would tend to show that either the Governor and Webster's agree as to the phonetic form of the name by coincldence, or on purpose, resulting from Mr. Smith's consulting the dictionary upon recelpt of the inquiry sent him. The Governor wrote concerning this question, "Replying to your inquiry of recent date as to my pronunciation of the name of our state, please be advised that I usually employ the following: Mí zoor 1."14 A quick glance at the nearest Webster's gazetteer shows that this form of phonetic spelling is identical with that submitted by the Governor. The question arising from both these replies is whether or not these prominent native sons have recorded their

13 Allen Walker Read, "The Pronunciations of the
word, 'Missouri," American Speech, 8:22-36, December, 1933.
1950. 14 Letter to the writer, Forrest Smith, January 12, 
respective pronunciations in fact or upon what they believe to be the "correct" pronunciation should be, based on their own dictionary research. Whichever the fact may be, this correspondence is of value in showing a definite trend away from the earlier pronunciation variations which invariably rendered the second consonant sound as an " $s$ " instead of the current " $z$ " sound.

One of the more important considerations arising in the earlier period of this investigation concerned the possibility and plausibility of requesting each Missouri radio news editor to send the writer tape recording samples of the most frequently made place-name pronunciation errors in his newsroom at the present time. The theory behind this proposition was that by hearing these errors first hand on our own University recording equipment, a more exact knowledge of the most common pronunciation variances could be learned. While this operation presented few difficulties as to obtaining this information from the stations which were kind enough to have answered previous inquiries, questions arose in the Department of Radio Journalism as to the actual value of such reports once recelved. Belleving that such an undertaking would be of far greater benefit to an investigation concerned with speech dialects or other Department of Speech problems, rather than concerned directly with the more generalized investi- 
investigation being made herein, the writer sent an inquiry to Bruce Barrington at Station KXOK, St. Louis, asking this interested news director's opinion with respect to this consideration. It was felt that while the KXOK director's opinion would not be final in the matter, it would be considered carefully on the basis of the sound advice already offered by this source.

In his reply, the Missouri radio newsman sald:

I am interested in the 1dea that you suggest for a recording of announcers' pronunciations. I feel this would be an interesting study in voice and inflection, but I do not feel it would assist in the project from the point of view of establishing a pronunciation guide. . . What is required is research to indicate the approved pronunciation and then an arbitrary definition of this research. You find yourself in a position of establishing authority and if I were you, this is what I would do. We are perfectly willing to take the pronunciations which you record.15

After additional thought and investigation into the matter the writer decided against this procedure, reasoning that since pronunciation faults were known to exist already, what difference did it make in a study such as this whether the fault lay in anglicization problems, spelling pronunciation errors, or the use of additional false guides in determining a given place-name pronunciation? 6, 1950 .

15 Letter to the writer, Bruce Barrington, January 
As the increasing problem of determining reliable sources with whom to verify local place-name pronunclations arose, letters were sent to press association radio news editors in an attempt to find out how those agencies handle this matter. From Chicago, Charles E. Ahrens, United Press division radio news editor, wrote:

As sources for pronunciations we use our own cables, the various consulates, Webster's New International unabridged dictionary, and established guides. Often you will find two different pronunciations as you go from source to source. In those cases, if its a foreign name, we check it through cables. Often, amusing incidents develop. For instance, one of our younger writers couldn't understand how an Irishman like Senator O'Mahoney of Wyoming could pronounce it oh-mah tuh-nee. He made it Oh-mah-ho'-nee and we took a spanking from indignant listeners. I think your project for a Missouri place-name guide is a fine thing. The Universities of Iowa and Illinois already have published such guides in this area and both have been given wide usage. 16

From the United Press New York City office further information was received with respect to that bureau's procedure in checking sources for pronunciations sent out from that headquarters to clients throughout the country. The response from this inquiry read in part:

In the case of persons, the 1deal source and one we use where possible is the person himself. When this is not possible, we inquire of members of the family, attorneys, employer or employees or other close and responsible associates. For places, we again go to

16 Letter to the writer, Charles E. Ahrens, January $12,1950$. 
the source, using the pronunciation favored by the inhabitants. Our source is the correspondent in the city or town, or in the case of remote areas, standard gazetteers and reference works. Where more than one pronunciation is correct, we use the one preferred by the majority of residents, In the case of two pronunciations equally popular, we use only one since it is our purpose to provide newscasters as quickly as possible with a correct phonetic spelling, rather than a list of all possible variations and the merits of each, which would be more confusing than helpful. A pronouncing dictionary, of course, would be more detalled in such instances.17

Answering in much the same vein as his United Press counterpart, Tom 0'Nell of the Assoclated Press, wrote: - . I've assumed that local stations would have intimate knowledge of local place-names, but the fact is that various state associations of AP member radio stations have been urging regional pronunciation guides as valuable especially for new announcers unfamiliar with particular localities. As a usual source in checking American place-names, the nearest AP bureau upon occasion would have to consult our correspondent in a particular locallty. You're right about the usual pronunclation being the one to use. 18

Unlike his New York wire service colleagues, John M. Cooper of the International News Service pointed out that INS does not carry pronunciations for domestic place-names. To do so, this radio news director contended, would crowd practlcally all news off the wire, and so INS leaves local

17 Letter to the writer, John J. Madigan, February 20, 1950.

18 Letter to the writer, Tom 0'Ne1l, February 13, 1950. 
place-name pronunciation verification entirely up to each client newsroom individually. 19

Checking with newsrooms closer to home concerning the sources normally used in verifying local place-name pronunciations proved of interest and importance to the methods later used in this investigation. In reply to a request to Station WDAF, Kansas City, respecting this matter, a member of that station's news staff replied:

Your efforts to complle a workable booklet of pronunciations for Missouri towns is a highly commendable project. Enclosed with this letter is a list of the most provoking names I could think of. Yes, we keep a small file which is far from being complete. . and. - we disagree among each other as to the pronunciations. We are all looking for an authentic guide and In certain your research will bring forth one. Please send us one of your first issues.20

Later on in this study, checking with this station again in an effort to determine the phonetic system or systems desired for inclusion in the pronunciation guide booklet, the writer received no response despite three inquiries sent. Inquiries made to stations in St. Louis, Jefferson City, Springfield, and Joplin, however, bore more fruitful results. In their replies, two of the four 1950.

19 Letter to the writer, John M. Cooper, February 21,

20 Letter to the writer, David E. Wisner, Jr., January 20, 1950. 
respondents indicated that simplified respellings would be sufficient to the needs of their news staff and their colleagues in that locality. A third reply urged respellings plus the International Phonetic Alphabet symbols. The fourth respondent said that if a second key was included in the Missouri guide booklet, it ought to be in the form of the standard dictionary markings, i.e., diacritical markings. The KXOK news director replied, "Our news people acound town feel that the simpler the guide the better. They say that additional markings might tend to confuse."2l The KWOS general manager at Jefferson City answered,"We feel that the system used by the press services, that of respelling, would be most suitable for our needs. We shall look forward to seeing the completed guide booklet."22

Joe Slattery, the assistant program director at Station KWTO, Springfield, advised that, "This pronunciation guide should carry the pronunciation written with the IPA and the respelling system. I do not care for diacritical marks at all."23 Station KFSB, Joplin, answered $9,1950$.

21 Letter to the writer, Bruce Barrington, March

22 Letter to the writer, (Miss) Catherine Roer, March 10, 1950. 1950.

23 Letter to the writer, Joe Slattery, March 6, 
this part of the correspondence by saying,

Both Station KSWM and Station WMBH agree with this station that the respelling system is the best for radio. A second key might be confusing to some, but if one is included, it is felt that the standard dictionary markings would be preferable. 24

Despite this apparent disagreement on the part of Missouri newsmen as to which of the several phonetic systems suggested would suit their needs best, the matter was arbitrarily settled to the satisfaction of the industry as a whole at the late spring meeting of the National Association of Radio News Directors held in Chicago. Under the leadership of the KXOK director of news, Missouri delegates along with those radio newsmen from other parts of the country decided in favor of the inclusion of the IPA symbols along with the simplified respellings. The Missouri place-name pronunciation guide is the first state guide to follow this recommendation.

Throughout this investigation attempts were made regularly to ascertain exact information from reliable sources with respect to how many other states had completed, were completing, or planned to begin work on similar projects for their respective radio industries. Initial correspondence dealing with this phase of the study was

24 Letter to the writer, Jim Randall, April 7, 1950. 
included in the first letters sent to $\mathrm{Dr}$. Arthur M. Barnes of the University of Iowa and Professor Donald E. Brown of the University of Illinois. Both these compilers, while devoting much time and effort to explaining much about their own surveys could offer little specific help concerning other similar works then underway. Most of the information received in the correspondence dealing with other state compilations came by way of a chance remark or brief suggestion on the part of the writer. In this manner definite knowledge was obtained concerning works in progress in Indiana, Texas, and Florida, and, in addition, it was learned that reports concerning the completion of similar projects for the states of Michigan, Arizona, and Oklahoma were unfounded. Likewise, as the result of correspondence carried out over this eleven months' study, completed place-name pronunciation guides for Iowa, Illinols, Kentucky, South Dakota, and W1sconsin have been deposited in the files of the Radio Journalism Department of the University of Missouri for permanent reference for students and faculty of the School of Journalism and other interested persons. Included in the correspondence received from the Transradio Press news director in New York City where several brief remarks on eastern projects of this type which might have been completed or underway for that part of the nation. This editor writes: 
I have been unable to trace any such publications in the East. I've made a number of inquiries, but have falled to turn up even one such booklet, or any leads to such a publication. A frend suggests that possibly state guide books turned out during the depression years by WPA writers have some pronunciation guides. I haven't seen any myself, but am shooting the idea along for what 1 t may be worth to you. 25

Unfortunately, perhaps, this suggestion was not followed up in this study. For the present, therefore, it is assumed that no eastern state has undertaken such a project. It is possible, of course, that later investigation concerning this matter may prove otherwise. No attempt was made by writing state universities to fine out the existence of such guides for the West Coast states, New England, the South or the Great Lakes region. Instead, an inquiry was sent to the United States Board on Geographic Names in Washington, D.C., in the hope that this centralized government agency could offer information as to how many individual states in the regions mentioned had undertaken or hoped to begin such guides. Unfortunately the response recelved from this national source made no mention of this matter whatsoever. This may have been owing to a misunderstanding of that part of the inquiry or simply a lack of knowledge on this point on the part of the respondent. Whatever the reason, no reference was made to $20,1950$.

25 Letter to the writer, Richard Wilson, February 
this question in a later reply received from this agency.

Several worthwhile references to other state placename pronunciation guide booklets in the process of just beginning or being completed were received from correspondents in Wisconsin, Indiana, and Iowa. One of the most helpful of these letters was that received from Jack $E$. Krueger, radio news editor of Station WTMJ, Milwaukee. He wrote:

I am checking whether or not the state of Wisconsin or its historical society has issued a place-name pronunciation guide. We at WTMJ have assembled our own pronunclation guide from various sources throughout the years, and it is a continuing project. Since we have listeners in Michigan and Upper Michigan, we also compile place-names from that state, which several years ago compiled a guide for broadcasters. You might inquire further about Michigan's from an NARND member in that state. 26

Although this reference proved valuable in verifying the fact that the state of Wisconsin had issued a master list of place-name pronunciations for that state in 1938, revising this list just ten years later, less fortunate results were obtained in the follow-up letter sent to Station WWJ, Detroit. This Michigan source replied:

After checking newscasters and The Detroit News library we have been unable to find any reference to such a publication. Our newscasters tell us they pronounce new names to the best of their ability and $27,1950$.

26 Letter to the writer, Jack E. Krueger, January 
continue using this pronunciation until corrected. This does seem to be a hit and miss operation, but they have never had any pronunciation guide. 27

This respondent added, however, that, "You have our best wishes and we feel a guide such as you are compiling would be of great value in the radio fleld."28 J. Larry

Beauchamp, currently compiling the Indiana place-name pronunciation guide, referred to the completed Kentucky guide which he had received at Purdue University in February, 1950, at the same time a copy of this booklet was recelved by the School of Journalism of the University of Missouri. Beauchamp, in explaining his plan of operation for verifying Indiana place-name pronunciations, remarked:

As things now look about five prominent people in each county will be contacted and asked to indicate the proper pronunciation of places about which we are in doubt. I'll probably write such people as the county judge, county superintendent of schools, radio stations in the county and the like. . . . I plan to include the names of all cities and towns in the state and all counties. It hasn't been settled yet as to whether or not names of rivers and streams or well-known places in the state will be included. I would be very happy to hear your comments and suggestions since I admit that I'm somewhat in the dark at times.29

27 Letter to the writer, Melvin C. Wissman, February 21, 1950.

28 Ibid., p. 1.

29 Letter to the writer, J. Larry Beauchamp, February 14, 1950. 
From this brief plan it may be seen that the Indiana compiler hoped to verify the pronunciations for that state's place-names in much the same manner as that decided upon for the Missouri place-name study.

At the suggestion of the Iowa guide compiler, a request for information was addressed to the University of Florida with respect to that state's current work on a place-name guide. Replying, Professor John Paul Jones of the Department of Journalism, wrote:

I am using all Florida names of cities and counties listed in the U.S. Postal Guide. I am getting my pronunciations from students who are native residents of the counties in which the towns and cities are located. I have compiled a list of the towns by counties. In some cases, I may submit troublesome pronunciations to chamber of commerce people in that community. 30

Professor Donald D. Burchard, compiler of the South Dakota guide in 1949, wrote that he is now compiling a similar work for Texas. Now on the faculty in the Department of Journalism, Agricultural and Mechanical College of Texas, he replied that, "We are planning a place-name guide for Texas and some work has been done on it already."31 With his previous experience in compiling the guide for 1950. 30 Letter to the writer, John Paul Jones, March 17,

31 Letter to the writer, Donald D. Burchard, February 1, 1950. 
South Dakota, this compiler should find his second state, though somewhat larger, just as challenging and interesting as was the first.

In addition to the unprofitable lead concerning the Michigan guide discussed already, similar luck was had with inquiries dealing with Arizona and Oklahoma. In verifying a reference found in earlier literature, a letter was sent to the University of Arizona requesting information on the book, Arizona Place Names by Will C. Barnes which appeared nationally for a brief time in the 1930's. In reply, Donald M. Powell, reference librarian, said:

Unfortunately no pronunciations are indicated in the Barnes book. Invaluable in all other respects, it is lacking in this feature. None of the other sources for Arizona names that I know of have pronunciations indicated. 32

Ben G. Henneke, answering on behalf of the state of Oklahoma from the University of Tulsa Department of Speech, wrote:

I was pleased to discover that you are working on a pronunciation guide for Missouri and want a copy of it for the Library when 1 it is finished. I wish some 1950.

32 Letter to the writer, Donald M. Powell, March 6, 
similar work were being conducted in Oklahoma, but I know of none. Best of luck!33

one of the most interesting parts of the investigation developed when a copy of the National Association of Radio News Directors continuing study of the major press associations was received by the Radio Journalism Department from NARND headquarters in Omaha, Nebraska. This study, begun in 1949, was conducted with the view toward finding out the merits and weaknesses of the several wire services which serve both newspapers and radio stations. Among the categories evaluated in this survey were the services' daily pronunciation guides on place-names and personal names, discussed at length in the preceding chapter of this investigation. Over a given period, assigned members of the NARND made analytical studies of the type names sent by each wire service, the frequency of such transmissions, and in what phonetic symbols these names were sent to clients throughout the nation. Although a relatively small amount of the over-all study was devoted to pronunciation, enough was learned by the organization's efforts to prompt letters being sent to Sheldon W. Peterson, director of news and special events at Station KLZ, Denver, Colorado, and Richard Oberlin, news director

33 Letter to the writer, Ben G. Henneke, March 29, 1950. 
at Station WHAS, Louisville, Kentucky. Since these two NARND members documented the survey results, it was hoped that one or both of them might be able to offer additional information on the pronunciation discrepancies found, if any, in this initial study. In reply, the KLZ director, describing the meaning of some of the results and purposes of this investigation, said:

. . I should tell you, too, that we had very little actual documentation of pronunciation discrepancies among the wire services. . . The demand for the published booklet has been so great that we had to limit its distribution to the NARND membership. Our study is pretty much of a pioneer effort and we realize that it had many shortcomings. As for a Colorado place-name pronunciation guide. there's none in existence. But, there is a great need for such a booklet and I am hopeful that something can be done about filling this need before too long. Your project is certainly a most worthwhile undertaking. 34

The director of news at the Louisville station, echoing much the same sentiments as those expressed by his Colorado counterpart, wrote:

Sheldon Peterson and I were not as greatly concerned with pronunciation as we were with the more vital, factual content of the various wire service reports. By all means please put me on the malling list for the Missouri Pronunciation Guide, and many thanks for being so thoughtful. You might contact John Bills at Station WQAM, Miami, Florida for more $21,1950$.

34 Letter to the writer, Sheldon W. Peterson, March 
detailed information on the 1949 survey and the one already underway in 1950.35

Following up this suggestion, the Miami news director replied that his only information on the subject was that found in the official report issued by NARND Executive Secretary, Soren Munkhof, of Station WOW, Omaha, Nebraska. He added, however:

I'll be glad to furnish you with a copy of the 1950 final report when it's ready for publication. . . . I'll keep an eye open for anything that turns up on place-name pronunciation and send it along to you. I'm glad to learn work is being done on a place-name guide for our state. Florida has so many Indian, French and Spanish names that I wonder the newscasters and announcers don't pop their cork every day. Long ago, I complled a list of the hardest Florida place-names for guidance of our news department. It has proved invaluable even though incomplete. 36

In his letter explaining the importance of including only local preference and usage in recording place-name pronunciations of foreign origin in general and Germany in particular, Harold A. Engel, assistant director of Station WHA, Madison, Wisconsin, and compiler of that state's pronunciation guide, remarked:

Frequently, even in commonly used names, there is a discrepancy between local preference and the conventional pronunciation. An example of that is Berlin. 1950.

35 Letter to the writer, Richard Oberlin, March 20, 36 Letter to the writer, John T. Bills, March 27, 1950. 
The German pronunciation puts the accent on the last syllable. As used here in Wisconsin, the accent goes on the first syllable. We strived to get the local pronunciation because people in a community are the most critical of mispronunciation. 37

Perhaps the most interesting single piece of correspondence received during this study was the letter sent by Erwin D. Canham, editor of The Christian Science Monitor, in reply to an inquiry for information concerning that newspaper's pronunciation guide for its affillated radio news service. This famous New England journalist replied:

We do not use a pronunciation guide for place-names in our writing of radio news copy. I do the radiocast myself and so far have been sufficiently familiar with the names of places in the news not to require a guide. As an inveterate traveler and as one who is familiar with several foreign languages, and with a staff even more thoroughly familiar with names in the news, we have not felt the need of a place-name pronunciation guide. 38

Although much of this correspondence lends itself to personal comments on the part of various radio news editors and other interested persons in the radio industry and outside it with respect to their opinions and hopes for the success of the Missouri place-name pronunciation guide, such remarks are of value to this investigation because

37 Letter to the writer, Harold A. Engel, February 28, 1950 . 1950.

38 Letter to the writer, Erwin D. Canham, March 22, 
they tend to stimulate thought and comment on the problem as a whole and because special attention is directed also to the problems arising in the course of this study in particular. Many letters sent to other important persons within and outside the industry were never heard from in the course of the year's work. Other respondents directed the greater portion of their replies to propagandizing their own pet theories as to what a project such as this should and should not incorporate forgetting, in their enthusiasm, to answer the original questions posed. In all, however, these remarks herein included are felt to represent a typical cross-section of the total correspondence carried on throughout this investigation. These comments played a significant role in completing successfully the Missouri place-name pronunciation guide. 
CHAPTER VI

CONCLUSIONS AND RECOMMENDATIONS

The summary and conclusions drawn from this investigation have been incorporated into a Guide to the Pronunciation of Missouri Place-Names for use by Missouri broadcasters and other interested persons. The Guide to the Pronunciation of Missouri Place-Names constitutes the largest portion of this chapter.

Pronunciations in the guide which were recelved from sources other than the questionnalre were obtained from the eighteen Master's theses on Missouri place-names completed by the Department of English, from A Dictionary of American English by John S. Kenyon and Thomas A. Knott, by interviewing University students from the places in question, by making a post card survey of the most ambiguous names by contacting county superintendents of schools, and by personal acquaintance with the pronunciation in question.

Where the same place-name was found to exist in more than one county, both counties have been placed in parentheses alongside the name. Likewise, where more than one usual pronunciation was found to be general in that locale, these variant pronunciations are recommended in the guide. Although the variant pronunciations are arranged with one necessarily preceding the other, no attempt is made herein 
to favor one pronunciation over the other.

Both the International Phonetic Alphabet symbols and a simplified respelling key are used to indicate each pronunciation in both the thesis and the guide booklet. It is felt that by including both systems, this investigation will prove of greter value to scholar and layman alike.

It is recommended that the Radio News Department of the School of Journalism adopt the Guide to the Pronunciation of Missouri Place-Names contained in this chapter, and it is suggested that the School of Journalism print the guide booklet in bulletin form for distribution to every Missouri radio stations, and to those persons participating in the investigation who requested a copy of the booklet. 



\section{PREFACE}

No guide to pronunciation can hope to satisfy every user with respect to the recommendations made as to the usual pronunciation of the place-names found within its covers. Rather, the compiler directs his efforts to the majority of users who can, in most instances, consult the listings with the assurance that for normal, everyday speech requirements, the recommendations are satisfactory. While no effort is made here to establish final authority on the pronunciations recommended, a sound basis for arriving at these recommendations was the investigation of this subject made by the writer. The guide is offered on the basis of the findings of that study.

The compiler wishes to thank Professor Edward C. Lambert, head of the School of Journalism Radio Department, for his help in drafting the initial steps in this investigation; Dr. Robert I. Ramsay of the Department of English for his help with the linguistic problems encountered and for his continuous assistance in seeing this guide brought to a successful conclusion; Dr. Earl F. English, Associate Dean of the School of Journalism, for recommending this project to the writer and for editing the booklet in its final form; and all the Missouri radio men and other interested persons who contributed their time and efforts 
throughout this work.

It is hoped this pronunciation guide to Missouri place-names will find a useful place in the newsrooms of every Missouri radio station as well as those in other states. It is also the purpose of this guide to be of some help to librarians, public speakers, and other interested persons both in Missouri and throughout the nation.

Donald George Picinich 


\section{THE INTERNATIONAL PHONETIC ALPHABET}

(as found in A Pronouncing Dictionary of American English by John S. Kenyon and Thomas A. Knott)

\section{Vowels}

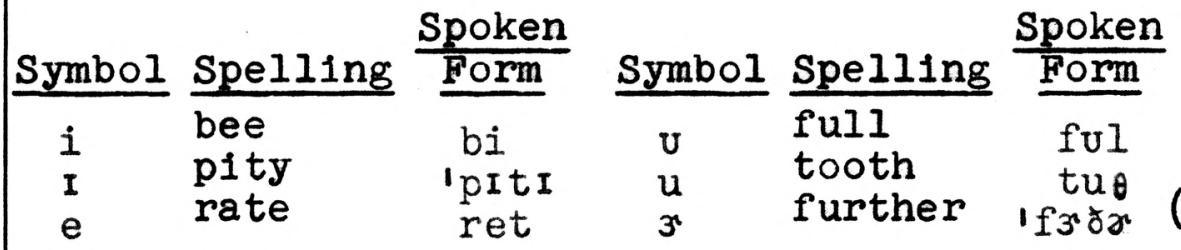

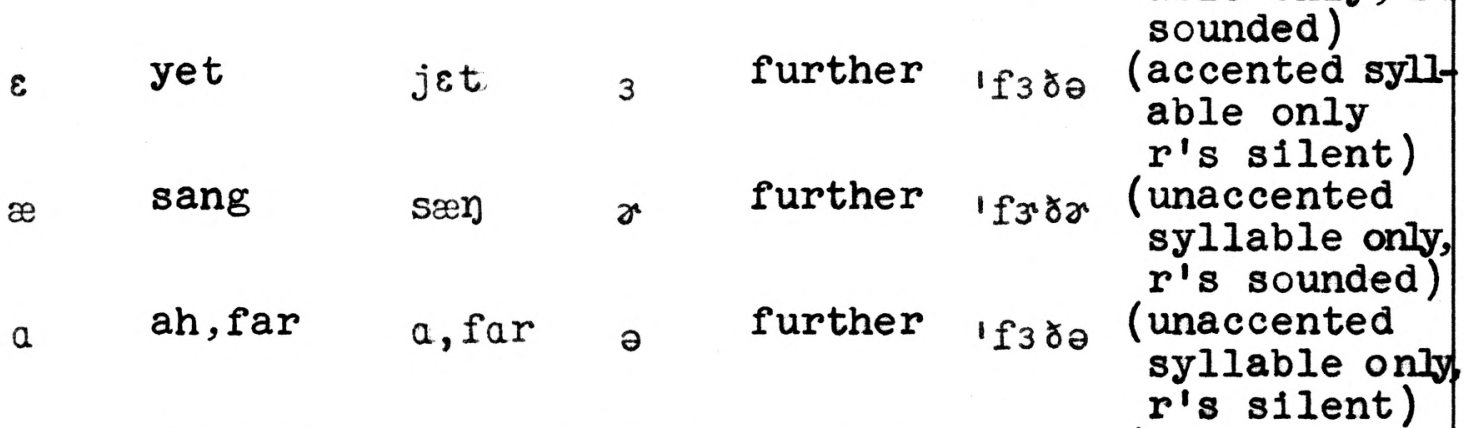

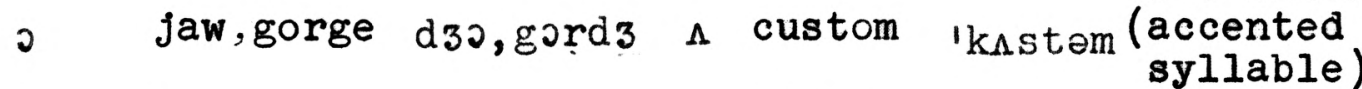

- go go above ə'b $\mathrm{b}$

\section{Diphthongs}

$\begin{array}{llllll}\text { aI } & \text { while } & \text { hwaIl } & \text { ju } & \text { using } \\ \text { au } & \text { how } & \text { hav } & & \text { fuse } & \text { fjuz } \\ \text { I I } & \text { toy } & \text { toI } & \text { Iu } & \text { fuse } & \text { fiuz }\end{array}$

Consonants

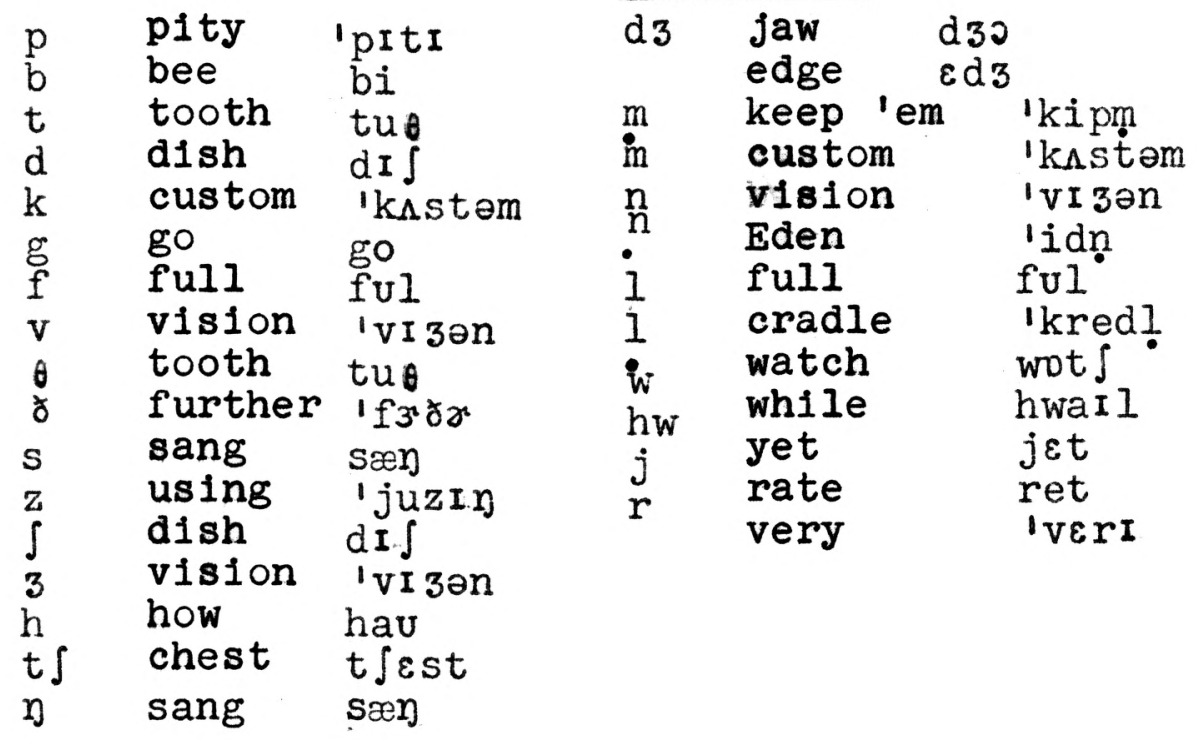




\section{SIMPLIFIED RESPELLING KEY}

Symbol

a

ay

ah

air

aw

e

ee

1

eye

0

oh

oo

yoo

$u$

uh

uhr

ow

O1

g

j

ng

$k$

$\mathrm{kw}$

th

dh

chq

sh

$\mathrm{zh}$

s

w

wh

y

\section{Equivalent}

is like the a in sat

is like the a in ate

is like the a in arm (also the usual American pronunciation of 0 in such words as pot, God, Tom)

is like the ar in care

is like the aw in law

is like the $e$ in bet

is like the $e$ in me

is like the $i$ in hit

is like the $i$ in ice

is like the 0 in for

is like the 0 in toe

is like the oo in mood

is like the ew in pew

is like the $u$ in pull

is like the a in sofa or above, e in quiet,

$i$ in April, 0 in gallop, $\bar{u}$ in suppose or cup is like the ur in burn, or the last sylla-

ble of paper, liar, sailor, augur

is like the $\overline{O W}$ in $\overline{O W}$

is like the oy in boy

is like the $g$ in $g \circ$

is like the $j$ in jump

is like the ng in singer (but not like the $\mathrm{ng}$ in finger, which equals fingguhr, nor the ng in ginger which equals Jinjuhr) is like the $c$ in can

is like the qu in quick

is like the th in thin

is like the th in then

is like the ch in chain

is like the sh in dash

is like the $s$ in vision

is like the $s$ in sit

is like the $w$ in wave

is like the wh in when

is like the $y$ in yes

is like the $z$ in zebra

Other consonants have normal English values.

Accented syllables are capitalized. 


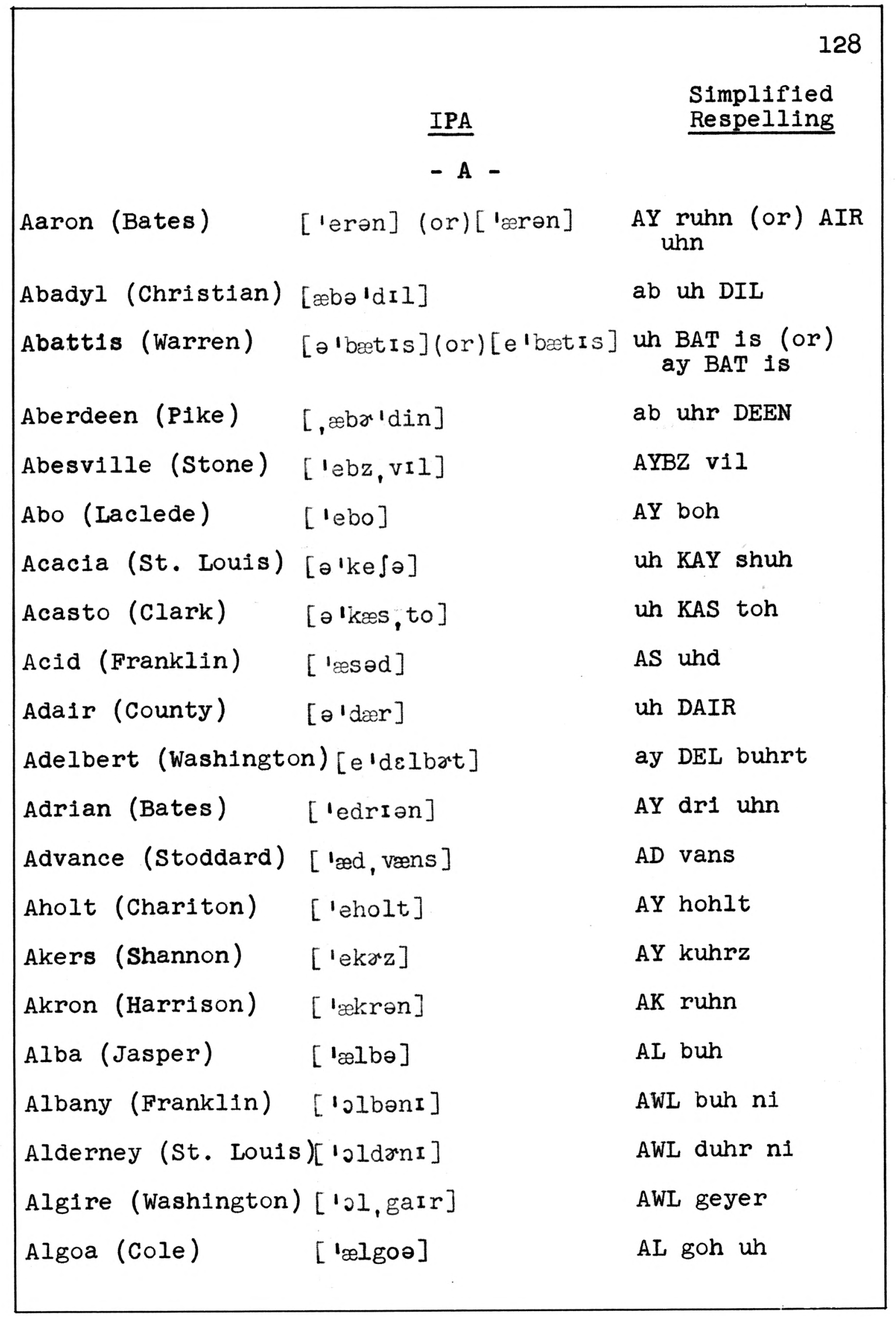




\begin{tabular}{|c|c|c|}
\hline & IPA & $\begin{array}{l}\text { Simplified } \\
\text { Respelling }\end{array}$ \\
\hline Alhambra (Stoddard) & {$[, æ l$ 'hæmbr $]$} & al HAM buhr \\
\hline Alice (Texas) & ['ælis ] (or)[ $æ l ə s]$ & AI is (or) AL uhs \\
\hline Allamongs (Carroll) & ['ælømanz] & AL uh mahngz \\
\hline Alley (Shannon) & {$[' œ 1 I]$} & AL 1 \\
\hline Alliance (Bollinger) & [ə'larəns] & uh LEYE uhns \\
\hline Alma (Lafayette) & ['ælmə] & AL muh \\
\hline Almartha (Ozark) & {$[\operatorname{l} æ \operatorname{lmar} \theta \partial]$} & AL mahr thuh \\
\hline Altamont (Daviess) & {$[$ 'æltə, mant $]$} & AL tuh mahnt \\
\hline Altenburg (Perry) & ['æltən, brg] & AL tuhn buhrg \\
\hline Amazonia (Andrew) & 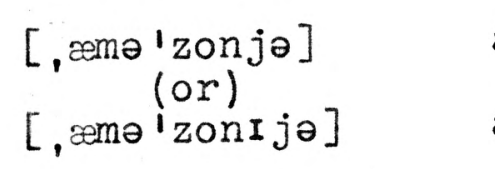 & $\begin{array}{l}\text { am uh ZOHN yuh } \\
(\text { or }) \\
\text { am uh ZOHN \& yuh }\end{array}$ \\
\hline Americus (Montgomery) & [ə'mærIkəs] & u. MAIR i kuhs \\
\hline Amity (De Kalb) & ['mmItI $]$ & $\mathrm{AM} i \mathrm{ti}$ \\
\hline Amoret (Bates) & {$[\operatorname{l} x m \ominus, r \varepsilon t]$} & AM uh ret \\
\hline Amory (Clay) & {$[1 \mathrm{em}, \mathrm{rI}]$} & AYM ri \\
\hline Anaconda (Franklin) & {$[$,ænə'kandə] } & an uh KAHN duh \\
\hline Ancell $(S \cot t)$ & ['œnsəl] & AN suhl \\
\hline Andre (Vernon) & {$[$ 'ændrI] } & AN dri \\
\hline Annada (Pike) & {$[$ 'æn, edə] } & AN ay duh \\
\hline Annapolis (Iron) & {$[, æ n$ 'œpəlis $]$} & an NAP uh lis \\
\hline Anniston (Mississippi) & ['ænəstən] & AN uhs tuhn \\
\hline $\begin{array}{l}\text { Anthonies Mill } \\
\text { (Washington) }\end{array}$ & {$\left[\begin{array}{ll}\operatorname{m} \circledast n \theta ə n I z & \operatorname{mI} I]\end{array}\right.$} & AN thuh niz mil \\
\hline Anutt (Dent) & {$[$ 'ænət $]$} & AN uht \\
\hline
\end{tabular}




\begin{tabular}{|c|c|c|}
\hline & IPA & $\begin{array}{l}\text { Simplified } \\
\text { Respelling } \\
\end{array}$ \\
\hline Apex (Lincoln) & {$[$ 'e, peks $]$} & AY peks \\
\hline Aquilla (Stoddard) & {$\left[\partial^{\prime} \mathrm{kWI} l \partial\right]$} & uh KWIL uh \\
\hline Arab (Bollinger) & {$[1 e, r æ b]$} & AY rab \\
\hline Arbela (Scotland) & [ar'bilə] & ahr BEE luh \\
\hline Arbyrd (Dunklin) & ['arbrd] & AHR buhrd \\
\hline Arcadia (Iron) & {$\left[\operatorname{ar}{ }^{\prime} k e d I \partial\right]$} & ahr KAY di uh \\
\hline Archie (Cass) & {$\left[\operatorname{art} \int I\right]$} & AHR chi \\
\hline Arcola (Dade) & [ar'kole] & ahr KOH luh \\
\hline Ardeola (Stoddard) & {$[, \operatorname{ard} I$ 'ol $\theta]$} & ahr di OH luh \\
\hline Argentville (Lincoln) & {$[\operatorname{lard} 3 ə n t, v I I]$} & AHR juhnt vil \\
\hline Argo (Franklin) & $[$ 'ær,go $]$ (or) [ 'ar, go $]$ & $\begin{array}{l}\text { AIR goh (or) AHR } \\
\text { goh }\end{array}$ \\
\hline Argola (Lewis) & {$[\operatorname{arc} \operatorname{gol} \theta]$} & ahr GOH Iuh \\
\hline Argonne (Lafayette) & {$[\operatorname{lar}, g \circ n]$} & AHR gawn \\
\hline Argyle (Osage) & {$[\operatorname{lar}, \operatorname{gar} 1]$} & AHR geyel \\
\hline Arkansas (State) & {$[\operatorname{lark} ə n, \mathrm{so}]$} & AHR kuhn saw \\
\hline $\begin{array}{c}\text { Arkansas (city in } \\
\text { Kansas) }\end{array}$ & [ar'kænzəs] & ahr KAN zuhs \\
\hline Arkoe (Nodaway) & {$[\operatorname{lar}, \mathrm{ko}]$} & AHR koh \\
\hline Arnica (Cedar) & ['arnIkə] & AR ni kuh \\
\hline Arnold (Jefferson) & ['arnəld] & AHR nuhld \\
\hline Atchison (County) & {$\left[\right.$ 'æt $\left.\int ə s ə n\right]$} & ATSH uh suhn \\
\hline Athelstan (Worth) & {$[' æ \theta \ominus 1, s t æ n]$} & ATH uhl stan \\
\hline Athens (Clark) & $\begin{array}{c}{[\text { 'æoənz] (or) }} \\
{[\text { leopnz }]}\end{array}$ & $\begin{array}{c}\text { ATH uhnz (or) } \\
\text { AY thuhnz }\end{array}$ \\
\hline
\end{tabular}




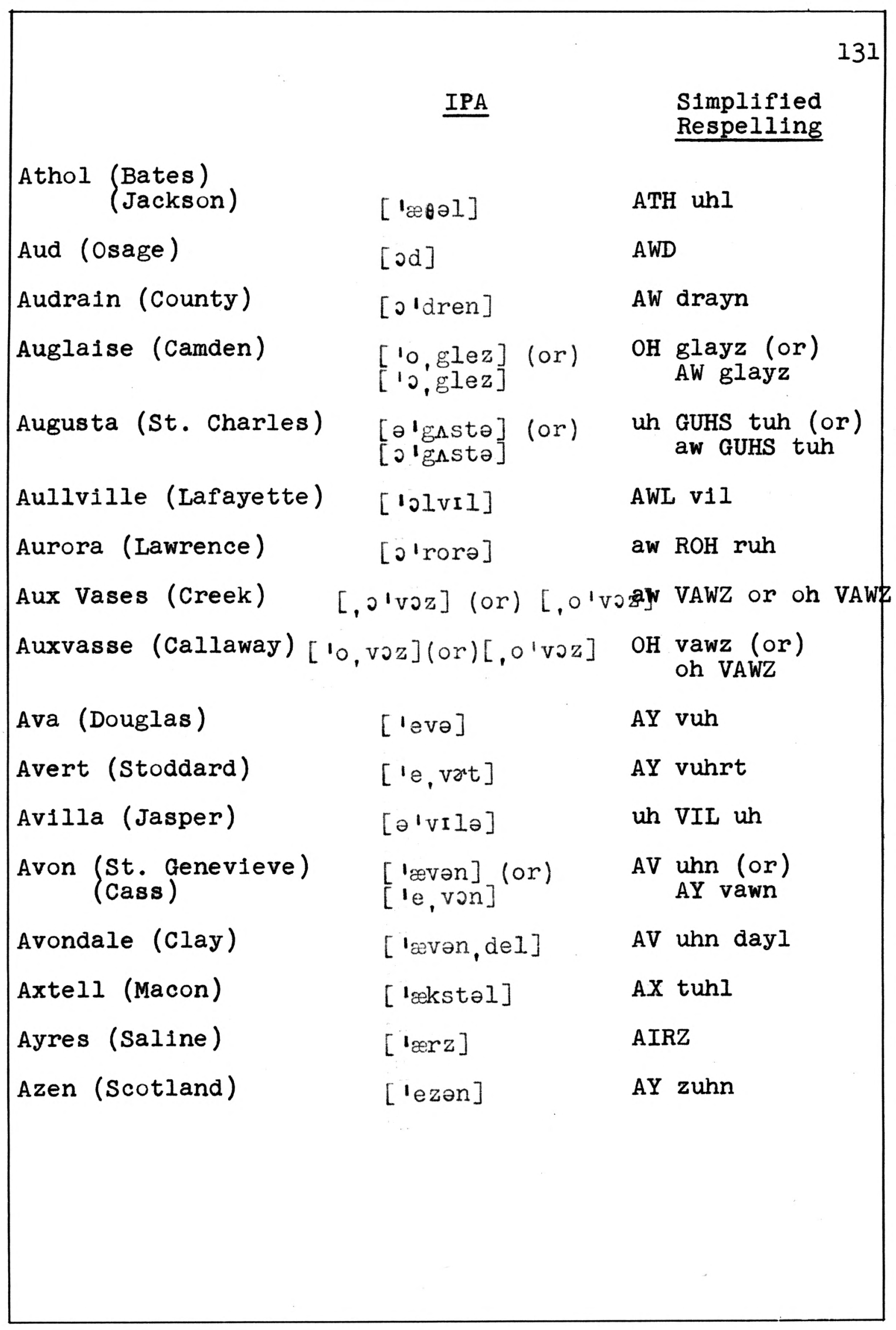




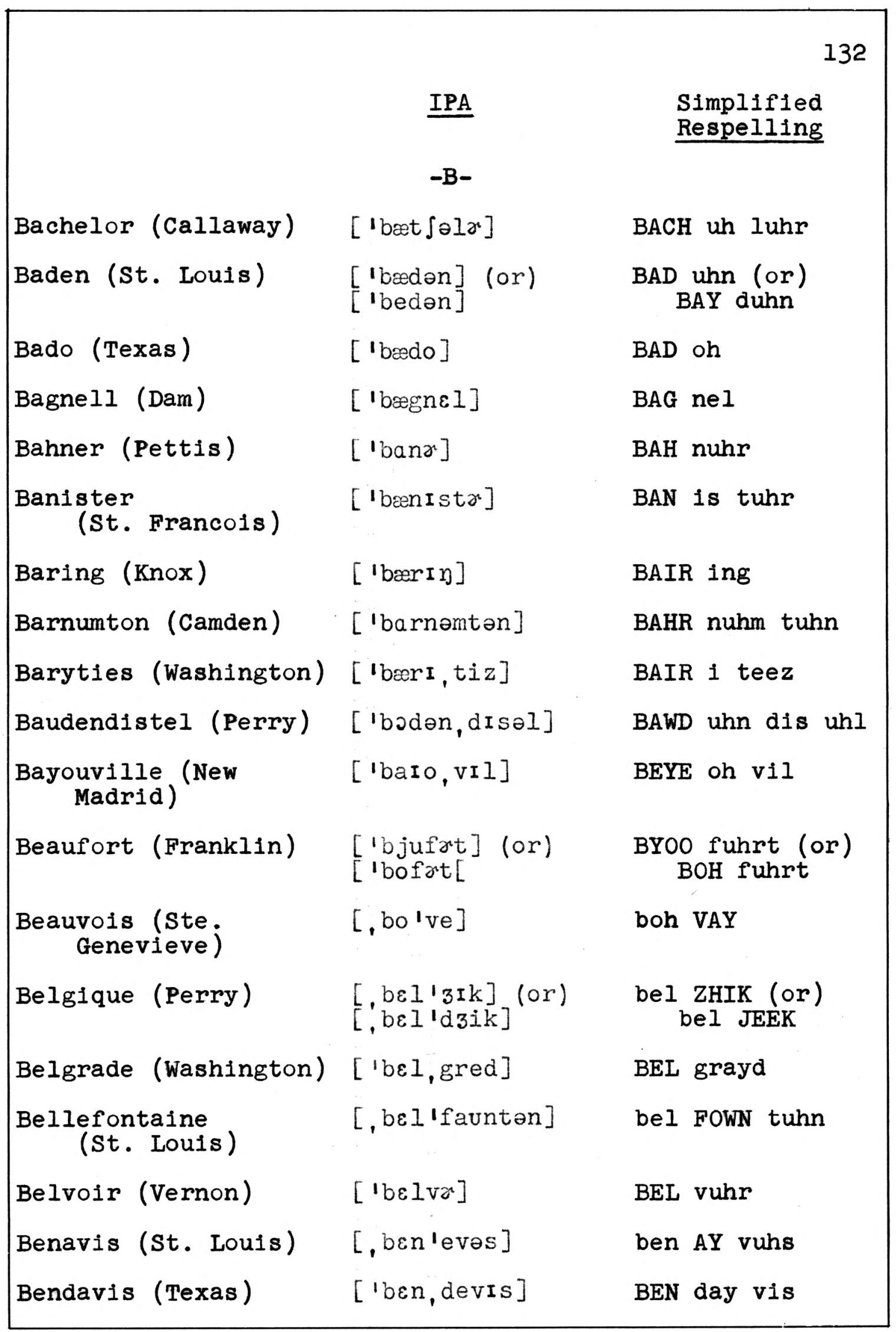




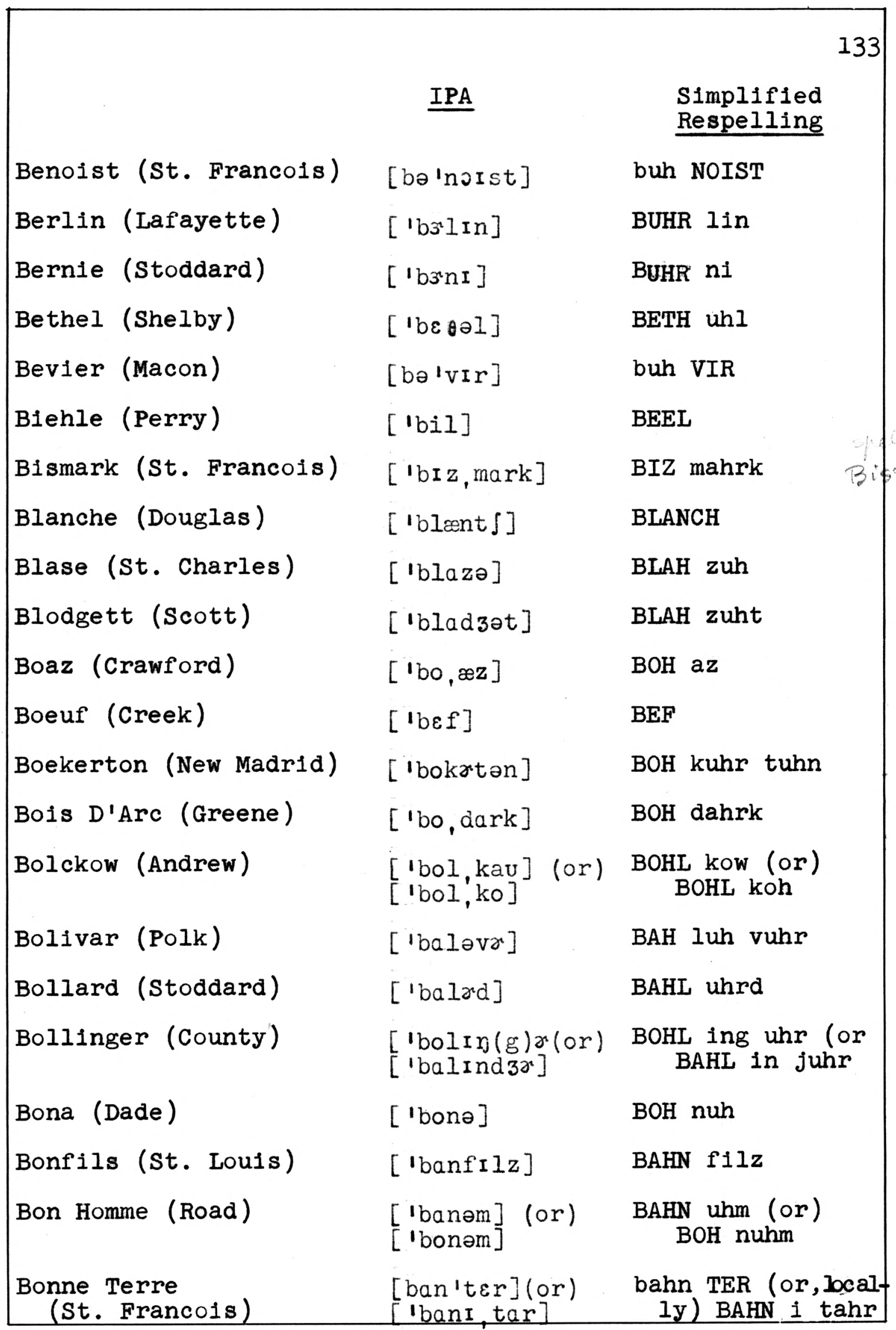




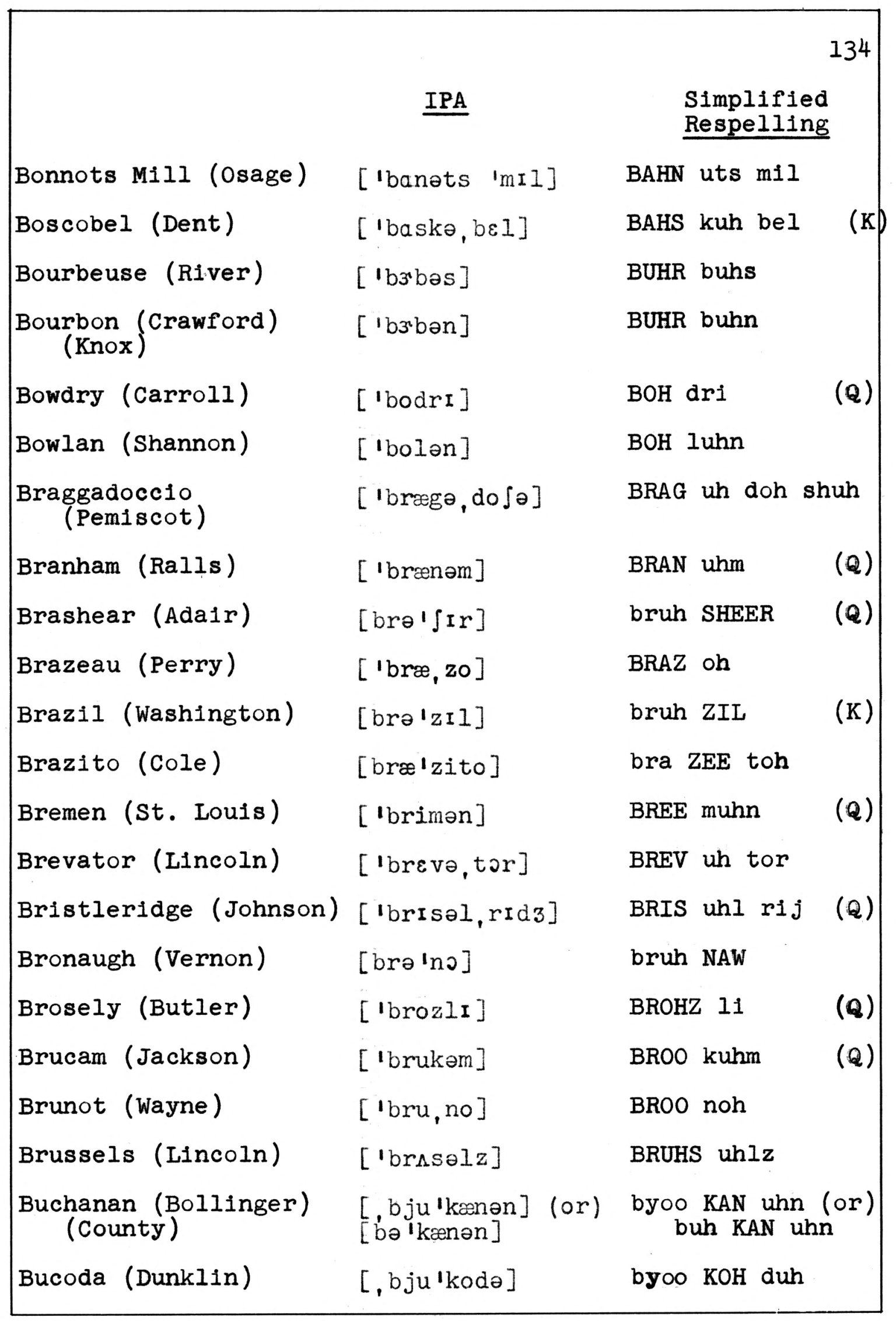




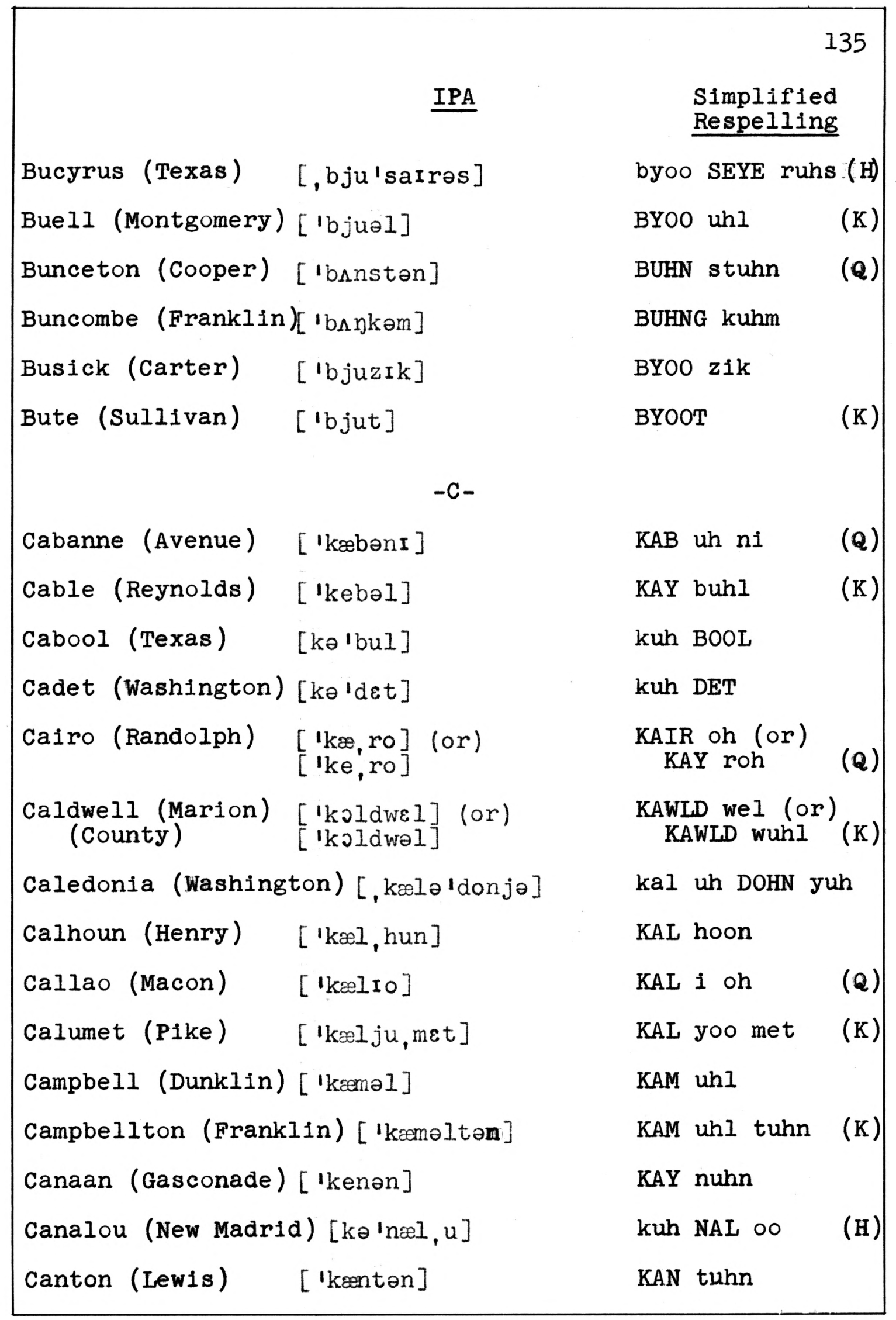




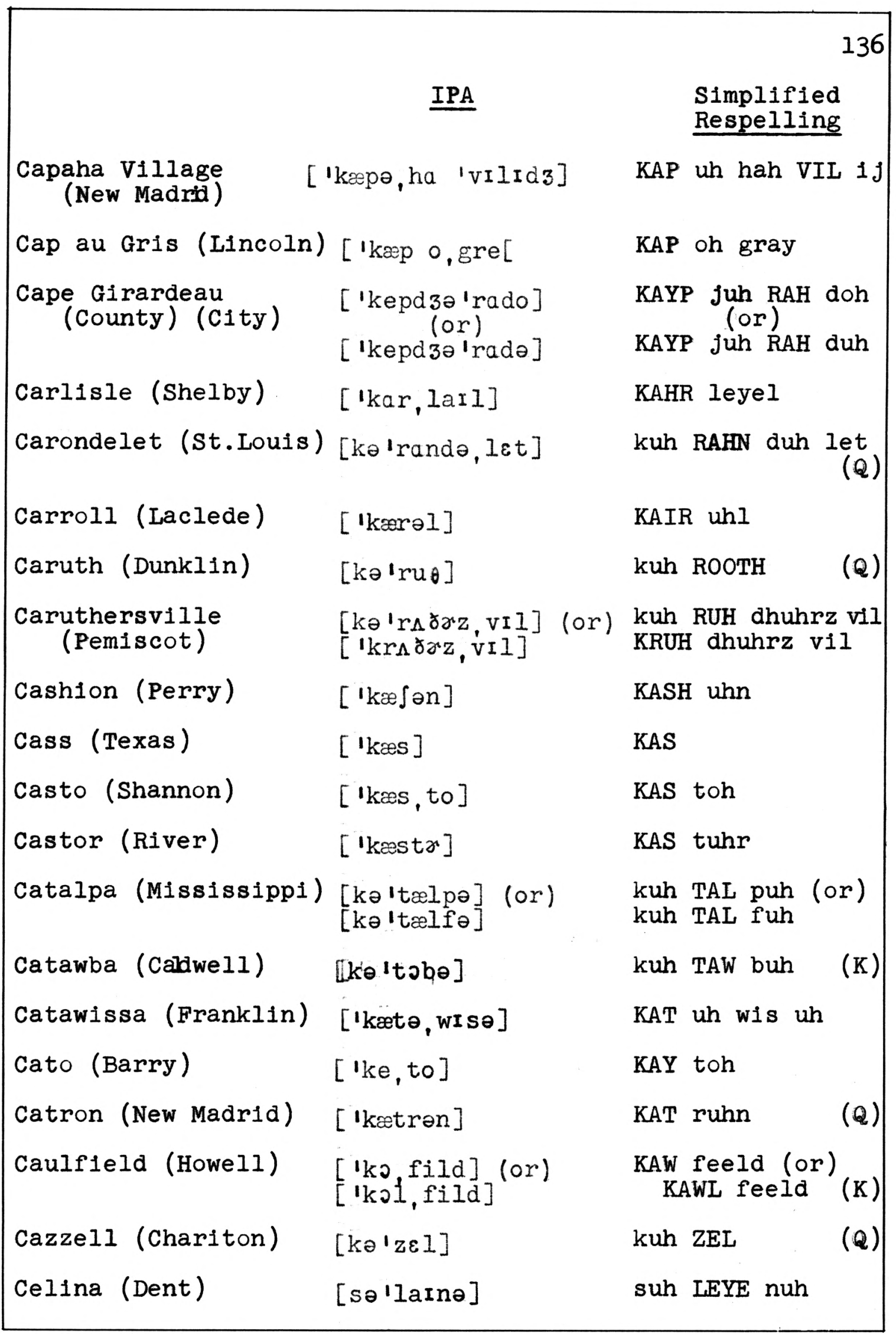




\begin{tabular}{|c|c|c|}
\hline & & 137 \\
\hline & IPA & $\begin{array}{l}\text { Simplified } \\
\text { Respelling }\end{array}$ \\
\hline Centralia (Boone) & {$[\operatorname{sen} \operatorname{trelj} j]$} & sen TRAYL yuh (Q) \\
\hline Chaffee $(S \cot t)$ & {$\left[' t \int æ, f i\right]$} & CHAF ee \\
\hline Chaminade (st. Louis) & {$\left[1 \int æ m ə, n a d\right]$} & SHAM uh nahd $(Q)$ \\
\hline Chamois (Osage) & {$\left[\iint^{\prime} \operatorname{moI}\right]$} & shuh MOI \\
\hline Chantilly (Lincoln) & 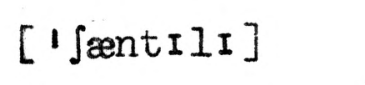 & SHAN ti $1 i$ \\
\hline Chaonia (Wayne) & {$[$ 'ke,onə] } & KAY oh nuh \\
\hline $\begin{array}{l}\text { Chariton (County) } \\
\text { (River) }\end{array}$ & ['SærItən] & SHAIR i tuhn \\
\hline Charrette (Warren) & $\begin{array}{l}{\left[1 \int æ r ə t\right]} \\
{\left[\int \partial^{\prime} r \varepsilon t\right]}\end{array}$ & $\begin{array}{l}\text { SHAIR uht (or) } \\
\text { shuh RET }\end{array}$ \\
\hline Chelsea (St. Louis) & {$\left[\mid t \int \varepsilon \operatorname{lsI}\right]$} & CHEL si \\
\hline Chicopee (Carter) & {$\left[\operatorname{tt} \int \mathrm{rk} \theta, \mathrm{pi}\right]$} & CHICK uh pee \\
\hline Chilhowes (Johnson) & $\left.\left[\operatorname{t} \int \mathrm{I}\right], \mathrm{havI}\right]$ & CHIL how $i$ \\
\hline $\begin{array}{l}\text { Chillicothe } \\
\text { (Iivingston) }\end{array}$ & {$\left[, t \int I I \partial^{\prime} k a \theta I\right]$} & chil uh $\mathrm{KAH}$ thi \\
\hline $\begin{array}{l}\text { Chilliticaux (Cape } \\
\text { Girardeau) }\end{array}$ & $\left.\left[\mathrm{t} \int \mathrm{I}\right] \partial \mathrm{t} \theta, \mathrm{ko}\right]$ & CHIL uh tuh koh \\
\hline Chitwood (Jasper) & [ It $\left.\int \mathrm{rtwud}\right]$ & CHIT wuhd \\
\hline Chloe (st. Clair) & {$[\mathrm{l} k \mathrm{loI}]$} & $\mathrm{KLOH} I$ \\
\hline Choat (Bollinger) & {$\left[\operatorname{te} \int \mathrm{ot}\right]$} & CHOHT \\
\hline Chouteau (Avenue) & {$[1$ so, to $]$} & $\mathrm{SHOH}$ toh \\
\hline Chula (Livingston) & {$[$ tesulə] } & CHOO Iuh \\
\hline Clara (Texas) & ['klærə] & KLAIR uh \\
\hline Claycomo (Clay) & {$[\mathrm{kle}$, komo $]$} & KLAY koh moh \\
\hline Clever (Christian) & {$[\mathrm{l} / \mathrm{k} \varepsilon \mathrm{v} r]$} & KLEV uhr \\
\hline
\end{tabular}




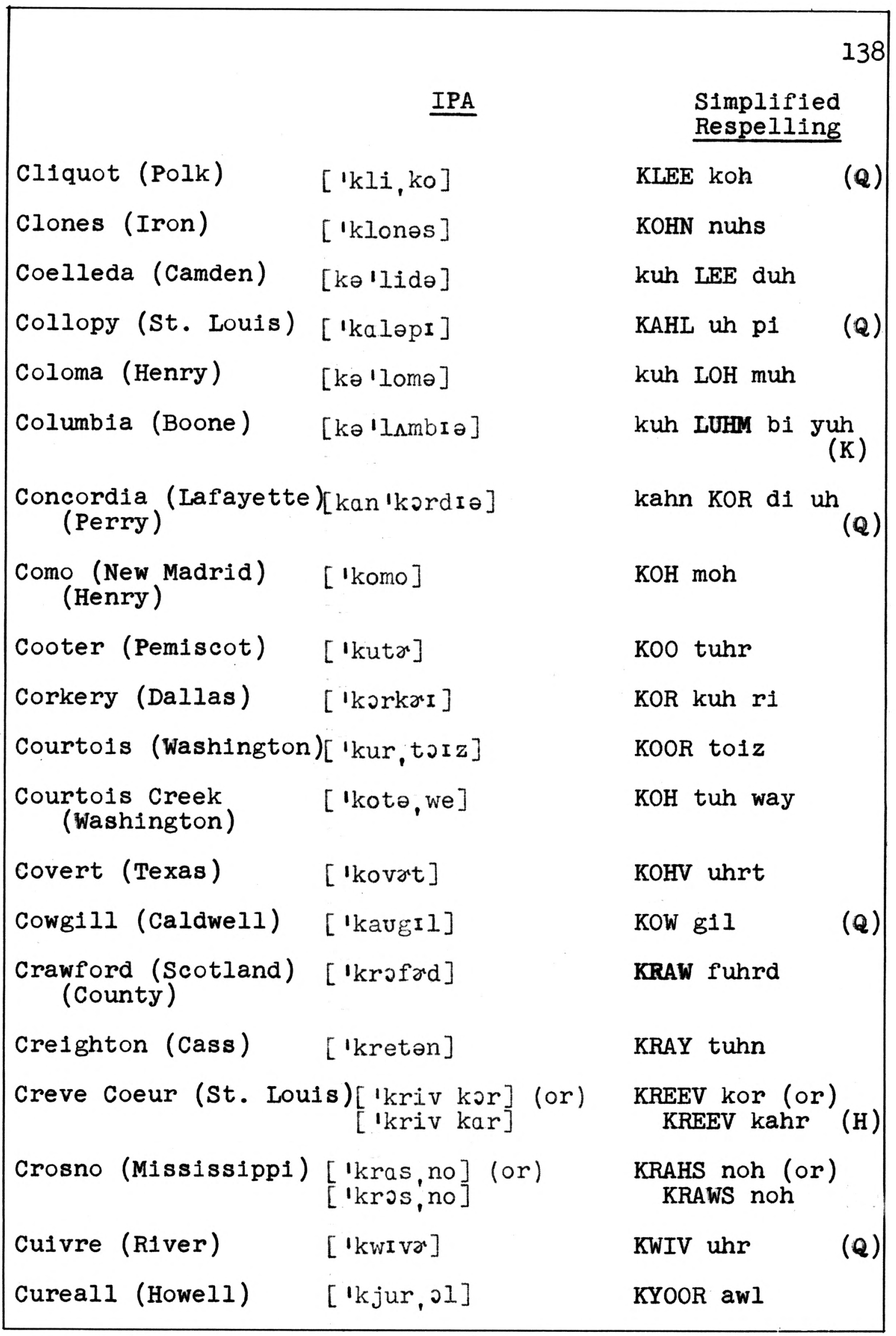




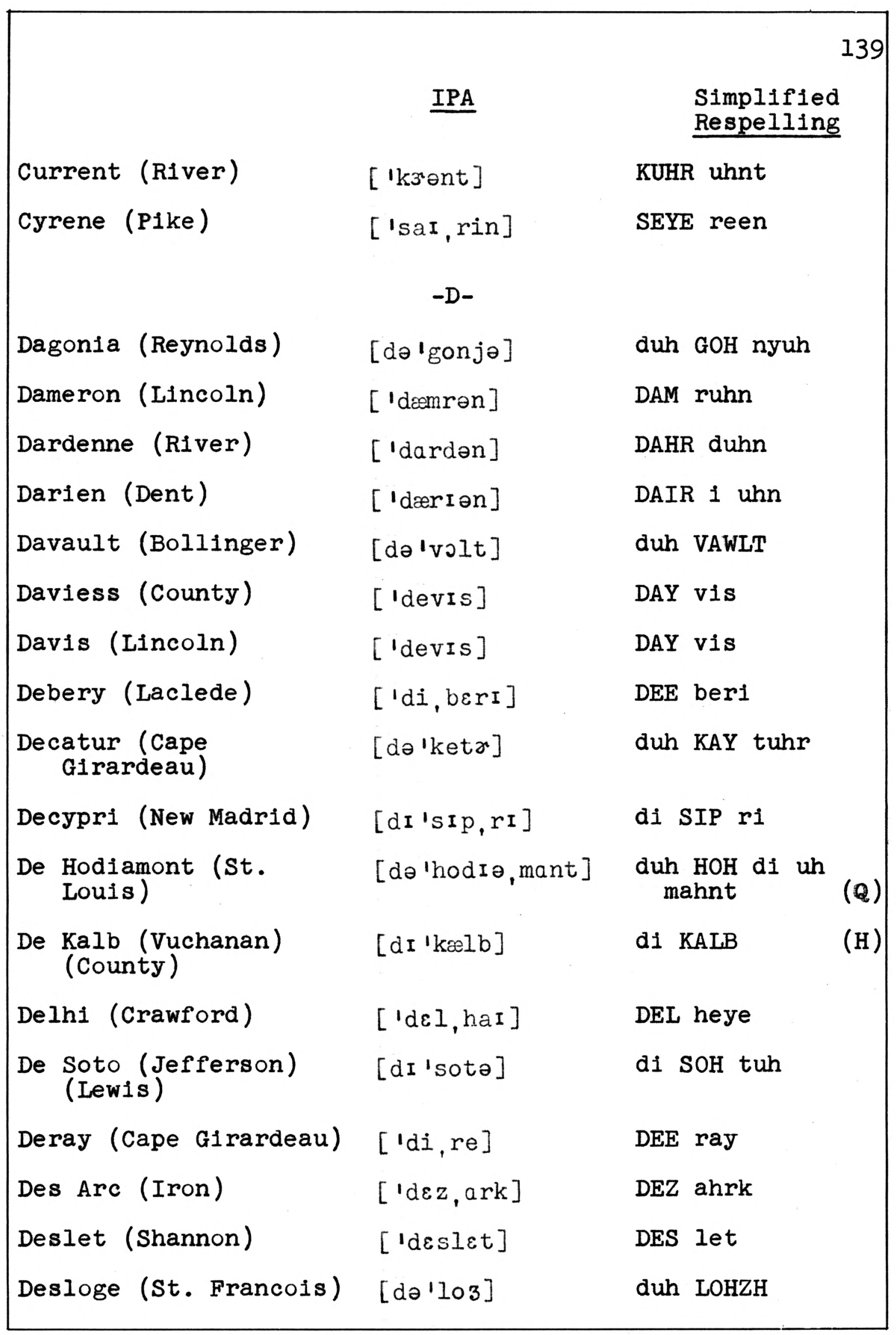




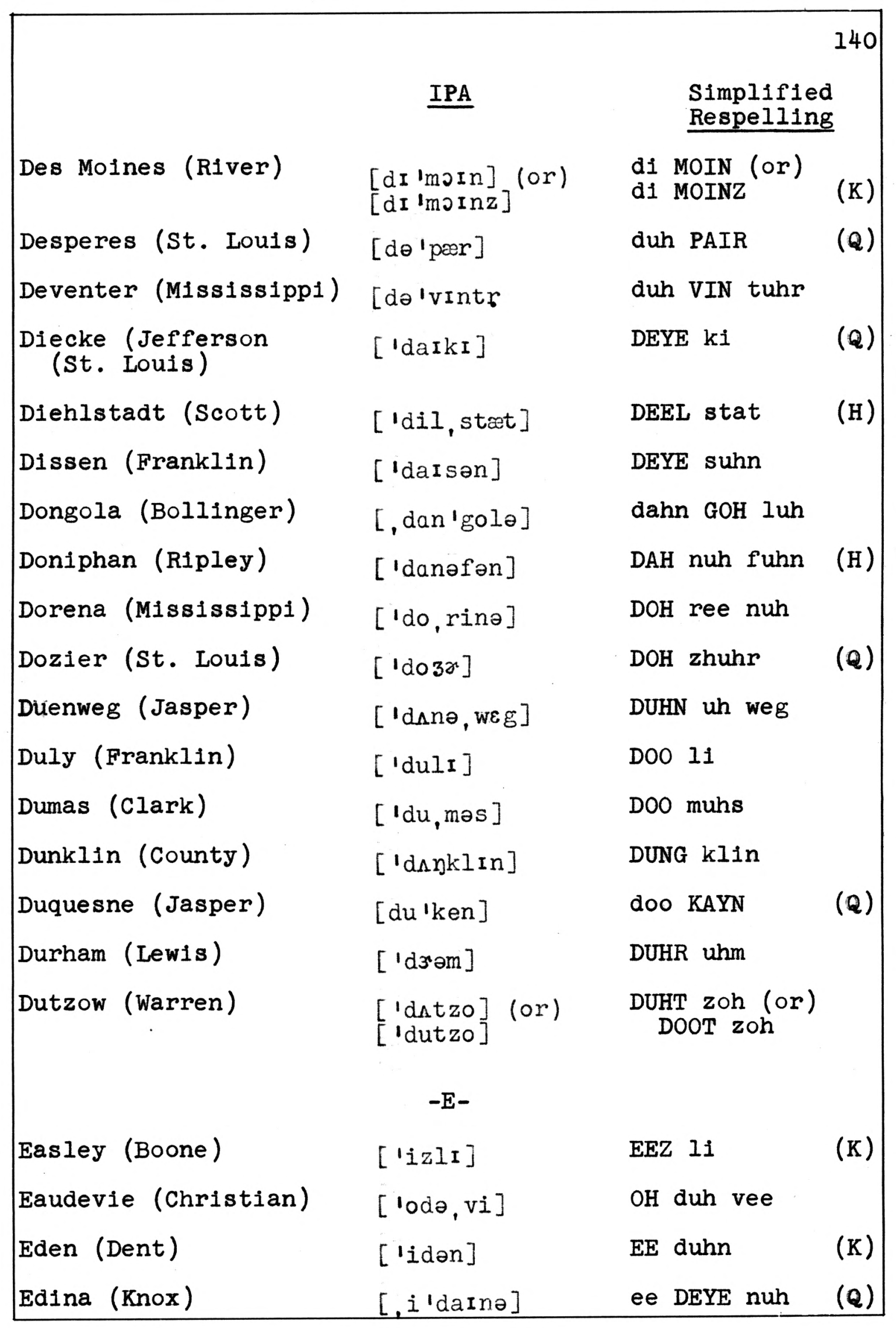




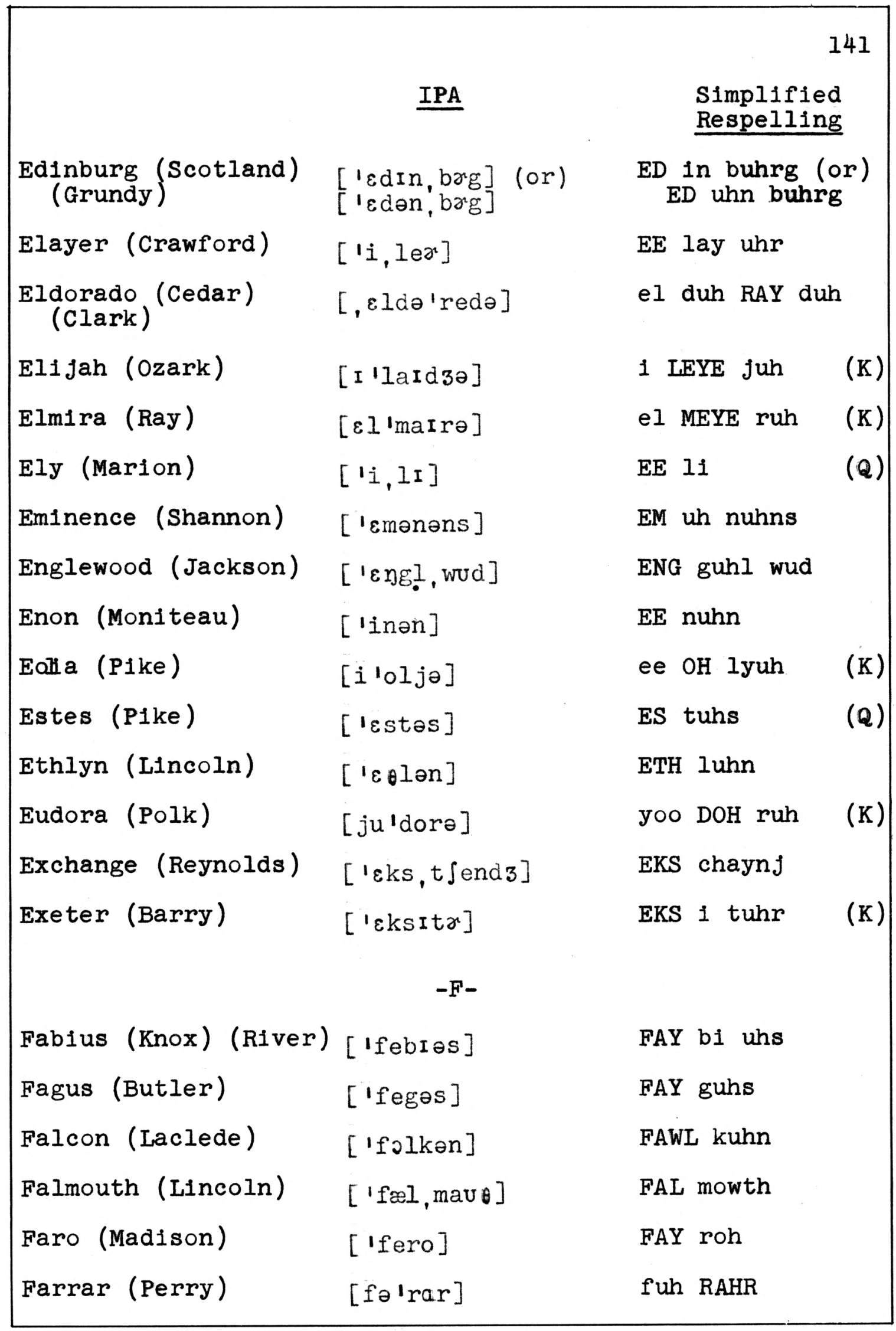




\begin{tabular}{|c|c|c|}
\hline \multirow[b]{2}{*}{ Faucett (Buchanan) } & $\underline{I P A}$ & $\begin{array}{l}\text { Simplified } \\
\text { Respelling }\end{array}$ \\
\hline & {$[$ fosit $]$} & FAW sit \\
\hline Faust (Pemiscot) & ['faust] & FOWST \\
\hline Fayette (Howard) & {$[' f e, \varepsilon t]$} & FAY et \\
\hline Florissant (St. Louis) & ['florəsənt] & FLOH ruh suhnt (Q) \\
\hline Foristell (St. Charles) & {$[$ 'forIs, tel] } & FAW ris tel \\
\hline Fortescue (Holt) & ['fortis,kju] & FOR tis kyoo \\
\hline Forsyth (Taney) & {$[$ Ifor, saI $\theta]$} & FOR seyeth \\
\hline $\begin{array}{l}\text { Fort Duquette (st. } \\
\text { Charles) }\end{array}$ & [fort du'ket] & fort doo KET \\
\hline $\begin{array}{l}\text { Fourche a Du Clos } \\
\text { (Ste. Genevieve) }\end{array}$ & [forfədə' $k l u]$ & forsh uh duh KLOO \\
\hline Fredonia (Ray) & {$[$ 'fri,donjə] } & FREE dohn yuh \\
\hline Freis tatt (Lawrence) & ['fraI, stæd] & FREYE stad \\
\hline $\begin{array}{l}\text { Frieden Gemeinde } \\
\text { (St. Charles) }\end{array}$ & ['fridən gə Ima & $\begin{array}{l}\text { PFREE duhn guh } \\
\text { MEYEN duh }\end{array}$ \\
\hline $\begin{array}{l}\text { Friedheim (Cape } \\
\text { Girardeau) }\end{array}$ & ['frid, haim] & FREED heyem \\
\hline Frohna (Perry) & ['frone] & FROH nuh \\
\hline & $-G-$ & \\
\hline $\begin{array}{l}\text { Galena (Franklin) } \\
\text { (Stone) }\end{array}$ & [gə'linə] & guh LEE nuh \\
\hline $\begin{array}{l}\text { Gallatin (Daviess) } \\
\quad \text { (Clay) }\end{array}$ & ['gælətən] & GAL uh tuhn \\
\hline $\begin{array}{l}\text { Gasconade (Laclede) } \\
\quad \text { (County) (River) }\end{array}$ & [, gæeskən'ed] & gask uhn AYD \\
\hline Gayoso (Pemiscot) & [ge'oso] & gay $\mathrm{OH}$ soh \\
\hline
\end{tabular}




\begin{tabular}{|c|c|c|}
\hline & IPA & $\begin{array}{l}\text { Simplified } \\
\text { Respelling }\end{array}$ \\
\hline Gideon (New Madrid) & {$[\lg I \mathrm{~d} I ə n]$} & GID i uhn \\
\hline Gilead (Lewis) & {$[\lg I I \ni d]$} & GIL i und \\
\hline Glasgow (Howard) & ['glæs, go $]$ & GLAS goh \\
\hline Golahy (Saline) & {$[$ 'golehI $]$} & GOH Iuh hi \\
\hline Gorin (Scotland) & {$[\operatorname{gor} \operatorname{In}]$} & GOR in \\
\hline Gower (Clinton) & {$[$ 'gav $x]$} & GOW uhr \\
\hline $\begin{array}{l}\text { Gravois Mills (St. } \\
\text { Louis) }\end{array}$ & ['græv৩I mIIz] & GRAV of Milz \\
\hline Guber (Reynolds) & $\begin{array}{c}{[\text { 'gobr }]} \\
-\mathrm{H}-\end{array}$ & GOH buhr \\
\hline Hahatonka (Camden) $[, \mathrm{h}$ & $a$,ha 'tanke] & hah hah TAHNG kuh \\
\hline Hahn (Bollinger) & ['han $]$ & HAHN \\
\hline Halcyon (Dent) & ['hælsI & HAL si uhn \\
\hline Hamestring (Bollinger) & ['hæmstrIn] & HAM string \\
\hline Hannibal (Marion) & ['hænəbə1] & HAN uh buhl \\
\hline Hardage (Shannon) & ['hardId 3$]$ & HAHRD $i j$ \\
\hline Harviell (Butler) & [ 'harvel] & HAHR vuhl \\
\hline Hayti (Pemiscot) & {$[$ 'he,taI } & HAY teye \\
\hline Heagy (Stoddard) & {$[\operatorname{lheg} I]$} & HAY gi \\
\hline Helena (Andrew) & {$[$ hə'Iine] } & huh IEE nuh \\
\hline Hematite (Jefferson) & {$[$ 'hemə,tart $]$} & HEM uh teyet \\
\hline Herculaneum (Jefferson) & {$\left[, h 3^{\prime} k j \partial^{\prime}\right.$ lenIəm] } & $\begin{array}{l}\text { huhr kyoo LAY ni } \\
\text { uhm }\end{array}$ \\
\hline Heumaders (Buchanan) & [hIu'medrz] & hyoo MAY duhrz (Q) \\
\hline
\end{tabular}


IPA

Hocomo (Howe11)

Holcomb (Dunklin)

Holstein (Warren)

Houck (Cape Girardeau)

Hough (New Madrid)

Houston (Texas)

Huiskamp (Marion)

Hunnewell (Shelby)

Huxie (Bollinger)

Huzzah (Crawford)

['havk]

[ $\ln \wedge f]$
Iantha (Barton)

Iatan (Platte)

Iberia (Miller)

Iconium (St. Clair)

Idalia (Stoddard)

Ilasco (Ralls)

(Marion)

Illinois (State)

IIImo (Scott) (Franklin) ['hokə, mo]

['halkəm]

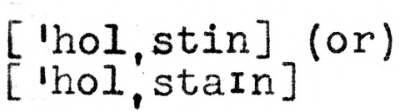

['hjuston] ['hus , kæmp $]$ (or)

['hanIwe1]

['hnksI]

$[$ 'hu, za $]$ (or) $-I-$

SIMPLIFIED RESPELLING

$\mathrm{HOH}$ kuh moh

HAHL kuhm

HOHL steen (or)

HOHL steyen

HOWK

HUHF

HYOO stuhn

(H)

HU si kamp (or)

WHIS kamp

HUHN 1 wel

(Q)

HUHK $\mathbf{~} 1$

HOO zah (or) HOO zaw

['aI,æn⿴囗十] EYE an thuh

['arə,tæn] EYE uh tan

[aI'bIrIo] eye BIR $i \operatorname{yuh}(K)$

['aI,konem] EYE koh nuhm

[aI'deljo] eye DAYL yuh

$\left[\partial^{\prime} l æ s, k o\right]$ un LAS koh

(Q)

[Ile'noI] (or) il uh NOI (or) il un NOIZ

$[I I$, mo $]$ II moh

Independence (Jackson) [Inda'pendens] in duh PEN duhns 


\begin{tabular}{|c|c|c|}
\hline \multirow{2}{*}{$+\cdot$} & \multicolumn{2}{|r|}{145} \\
\hline & IPA & $\begin{array}{l}\text { Simplified } \\
\text { Respelling } \\
\end{array}$ \\
\hline Inglesyde (St. Louis) & [Ing!'saId] & ingl SEYED \\
\hline Ionia (Benton) & [aI'onse] & eye $\mathrm{OH}$ ni uh \\
\hline Iowa (State) & ['aIəwə] & EYE uh wuh \\
\hline Irena (Worth) & [aI'rine] & eye REE nuh \\
\hline Ishmael (Washington) & {$\left[I \int \mathrm{m} I \partial I\right]$} & ISH mi uhl \\
\hline & $-\mathrm{J}_{-}$ & \\
\hline Jadwin (Dent) & {$[1 \mathrm{~d} 3 æ d w I n]$} & JAD win \\
\hline Jaeger (Franklin) & {$[' j e g x]$} & YAY guhr \\
\hline Japan (Franklin) & $\begin{array}{l}{[\text { 'd } 3 e, p e n] \text { (or) }} \\
{[\text { 'd } 3 \text { epən }]}\end{array}$ & $\begin{array}{l}\text { JAY pan (or) } \\
\text { JAY puhn }\end{array}$ \\
\hline Jaudon (Cass) & {$[\mathrm{d} d u, d o n]$} & Joo dawn \\
\hline Joachim Creek & $\begin{array}{l}{[\text { 'swa } \operatorname{In}]} \\
{\left[\text { 'swa } \int \operatorname{In}\right]}\end{array}$ & $\begin{array}{l}\text { SWAHSH in (or) } \\
\text { SWAHSH ing }\end{array}$ \\
\hline $\begin{array}{l}\text { Joplin (Jasper) } \\
\text { (Newton) }\end{array}$ & ['dzaplin] & JAHP Iin \\
\hline Juanita (New Madrid) & [, wo'nite $]$ & waw NEE tuh \\
\hline & $-\mathrm{K}-$ & \\
\hline Kahoka (Clark) & [kə'hokə] & kuh HOH kuh \\
\hline Kansas (State) & $\begin{array}{l}{[\text { 'kænzəs }] \text { (or) }} \\
{[\text { 'kænsəs }]}\end{array}$ & $\begin{array}{l}\text { KAN zuhs (or) } \\
\text { KAN suhs }\end{array}$ \\
\hline Kansas City (Jackson) & 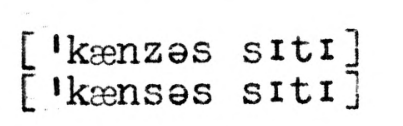 & $\begin{array}{l}\text { KAN zuhs (or) } \\
\text { KAN suhs }\end{array}$ \\
\hline Kaolin (Iron) & [ke'olin] & kay $\mathrm{OH}$ lin \\
\hline Kearney (Clay) & $\begin{array}{l}{[\text { 'karnI }] \text { (or) }} \\
{[\text { 'kærnI }]}\end{array}$ & $\begin{array}{l}\text { KAHR ni (or) } \\
\text { KAIR ni }\end{array}$ \\
\hline
\end{tabular}




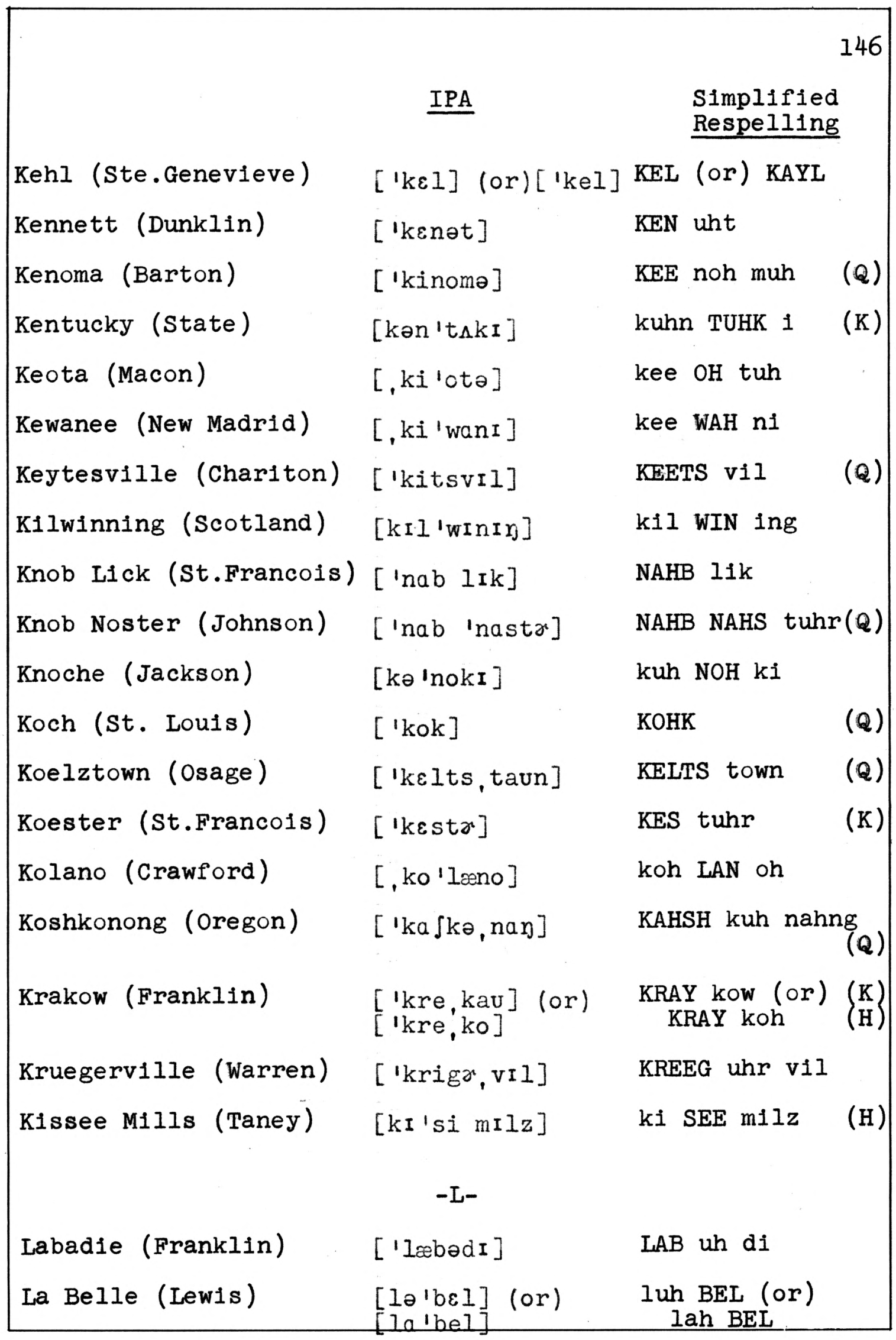




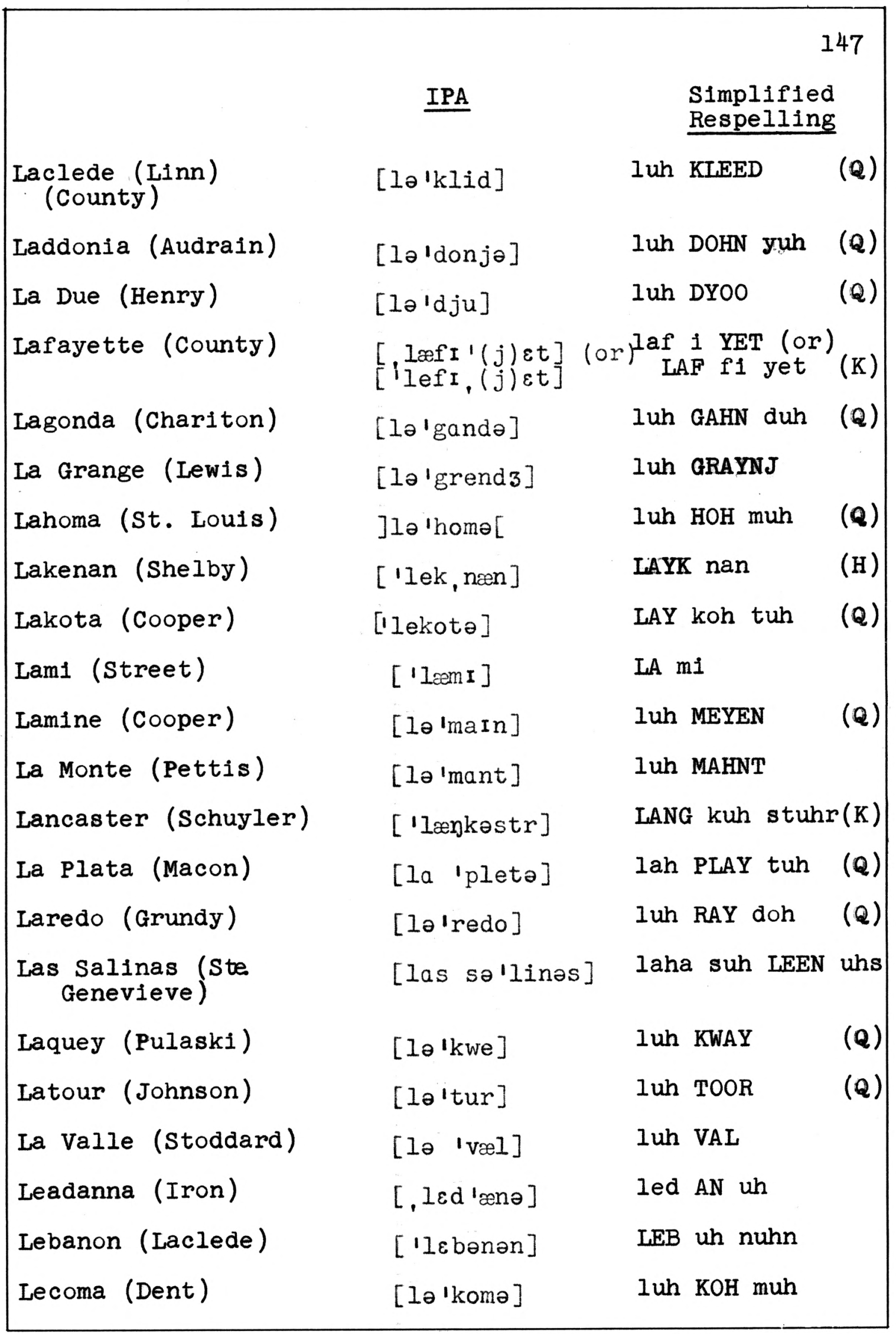




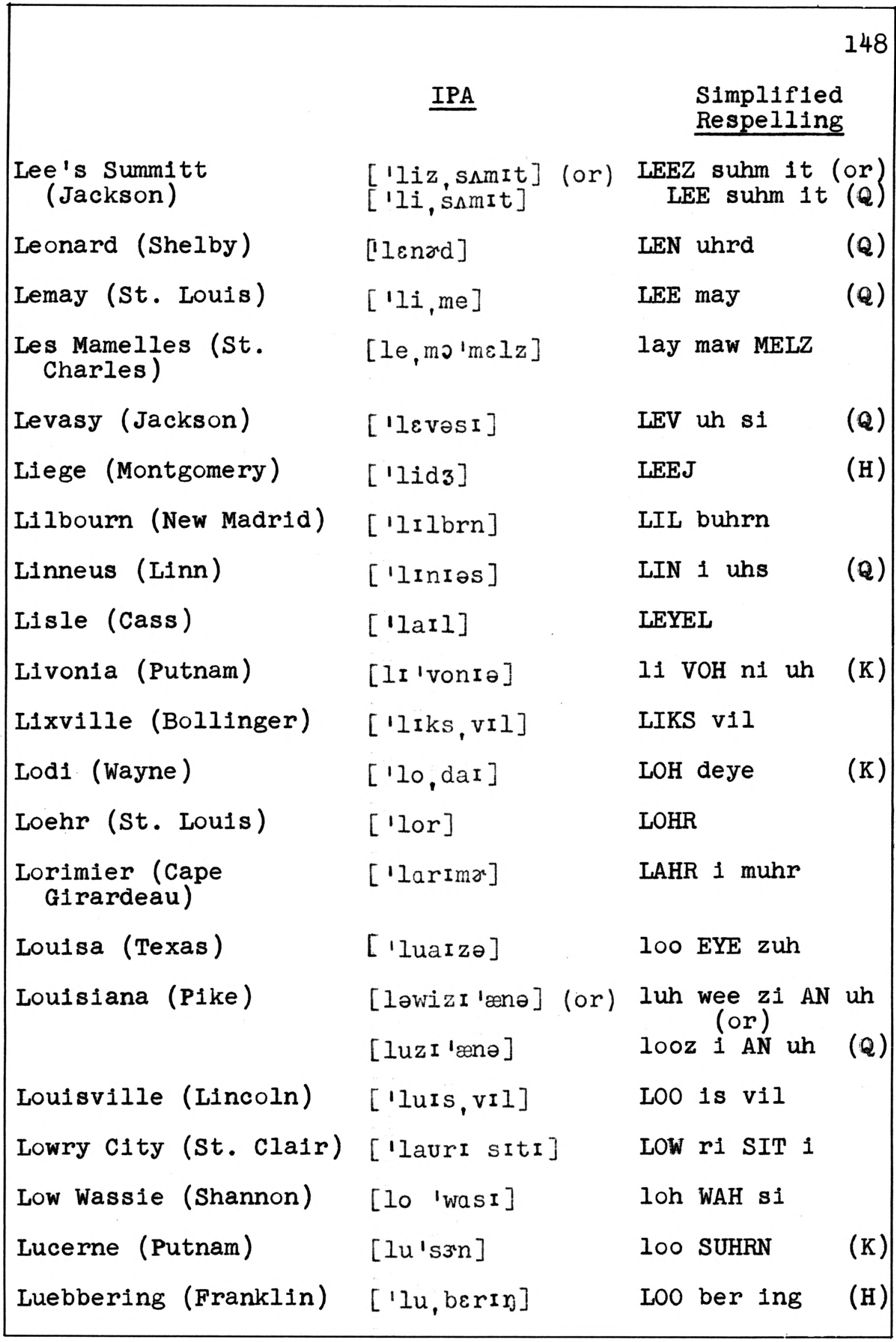




\begin{tabular}{|c|c|c|c|}
\hline & $\underline{I P A}$ & $\begin{array}{l}\text { Simplified } \\
\text { Respelling } \\
\end{array}$ & \\
\hline Lupus (Moniteau) & ['lupəs] & LOO puhs & (Q) \\
\hline Luray (Clark) & $['] u, r e]$ & Loo ray & (Q) \\
\hline Loutre (River) & $\begin{array}{c}{[\text { llutr }]} \\
-\mathrm{M}-\end{array}$ & LOO tuhr & \\
\hline McCredie (Callaway) & [ma'kredI] & muh KRAY di & (Q) \\
\hline Machens (St.Charles) & ['makənz] & MAH kuhnz & \\
\hline Mahan (Texas) & ['meən] & MAY uhn & \\
\hline Maitland (Holt) & ['metlend] & MAYT Iuhnd & (Q) \\
\hline Manes (Wright) & $\begin{array}{l}{[\text { 'menz }] \text { (or) }} \\
{[\text { 'menəs }]}\end{array}$ & $\begin{array}{l}\text { MAYNZ (or) } \\
\text { MAYN uhs }\end{array}$ & (H) \\
\hline $\begin{array}{l}\text { Marais Becket (St. } \\
\text { Charles) }\end{array}$ & [merI lbekIt] & meri Bek it & \\
\hline $\begin{array}{l}\text { Marais des Cygnes } \\
\quad \text { (River) }\end{array}$ & ['merdəzin] & MER duh zeen & \\
\hline $\begin{array}{l}\text { Marais Temps Clair } \\
\text { (St. Charles) }\end{array}$ & [merI tton klær] & meri TAWN klai & \\
\hline Marceline (Linn) & [marso'lin] & mar suh LEEN & (Q) \\
\hline Maries (County) & ['merIz] & MAIR iz & (Q) \\
\hline Marmaton (River) & ['marmətən] & MAHR muh tuhn & \\
\hline Marquand (Madison) & [mar'kwand] & mahr KWAHND & \\
\hline Mashek (Lincoln) & {$\left[\mathrm{Ima} \int \theta \mathrm{k}\right]$} & MAHSH uhk & \\
\hline Mattese (St. Louis) & {$[, m æ$ tis $]$} & ma Tees & (Q) \\
\hline Maupin (Franklin) & ['mapin] & MAH pin & \\
\hline Maurine (Henry) & {$[\operatorname{mo}, \mathrm{rin}]$} & MAW reen & \\
\hline Medoc (Jasper) & ['mi, dak $]$ & MEE dahk & (Q) \\
\hline
\end{tabular}




\begin{tabular}{|c|c|c|c|}
\hline \multirow[b]{3}{*}{ Melbourne (Harrison) } & \multirow{3}{*}{$\begin{array}{c}\text { IPA } \\
[\operatorname{Im} \varepsilon] \mathrm{b} r \mathrm{n}]\end{array}$} & \multicolumn{2}{|r|}{150} \\
\hline & & \multicolumn{2}{|c|}{$\begin{array}{l}\text { Simplified } \\
\text { Respelling }\end{array}$} \\
\hline & & MEL buhrn & $(\mathrm{K})$ \\
\hline Melugin (Jasper) & ['miləgIn] & MEE luh gin & \\
\hline Memphis (Scotland) & ['memfIs] & MEM $f$ is & $(\mathrm{K})$ \\
\hline Mendota (Putnam) & {$\left[\mathrm{men} \mathbf{I}^{\prime} \operatorname{dot} \partial\right]$} & men DOH tuh & $(\mathrm{K})$ \\
\hline $\begin{array}{l}\text { Meramec (St. Louis) } \\
\text { (River) }\end{array}$ & ['merə, mæk ] & MER uh mak & (Q) \\
\hline Meta (Osage) & ['mite] & MEE tuh & (Q) \\
\hline Metz (Vernon) & [mets] & METS & $(\mathrm{K})$ \\
\hline Mexico (Audrain) & ['meksIko] & MEKS $1 \mathrm{koh}$ & $(\mathrm{K})$ \\
\hline Miami (Saline) & {$[, \mathrm{maI}$ 'æmə] } & meye AM uh & $(\mathrm{K})$ \\
\hline Milan (Sullivan) & ['maIlən] & MEYE IUhn & \\
\hline Milo (Vernon) & ['maIIo] & MEYE loh & \\
\hline Mindenmines (Barton) & [mInden'maInz] & min den MEYEN & $\mathrm{JZ}(Q)$ \\
\hline $\begin{array}{l}\text { Mine La Motte } \\
\text { (Madison) }\end{array}$ & $\begin{array}{l}{\left[\operatorname{maIn} 1 \theta^{\prime} \text { mat }\right]} \\
(\text { or) } \\
{[\text { 'main lo'mot] }}\end{array}$ & $\begin{array}{l}\text { MEYEN I Uh MAF } \\
\text { (or) } \\
\text { MEYEN luh MOF }\end{array}$ & \\
\hline Mineola (Montgomery) & [mInI'olə] & $\min i \mathrm{OH}$ luh & (Q) \\
\hline Mingo (Stoddard) & ['mIngo $]$ & MING goh & \\
\hline $\begin{array}{l}\text { Mississippi (County) } \\
\text { (River) }\end{array}$ & {$[$ mIse'sIpI $]$} & mis uh SIP $i$ & \\
\hline$\underset{\text { (River) }}{\text { Missouri (State) }}$ & 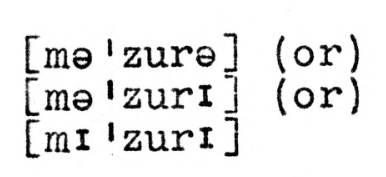 & $\begin{array}{l}\text { muh } 200 \mathrm{ruh} \\
\text { muh } 200 \mathrm{ri} \\
\mathrm{mi} z 00 \mathrm{ri}\end{array}$ & $\left(\begin{array}{l}\text { or } \\
\text { or }\end{array}\right)$ \\
\hline $\begin{array}{l}\text { Missouriton (St. } \\
\text { Charles) }\end{array}$ & [mə 'zurətən] & muh $z 00$ ruh $t$ & cuhn \\
\hline Moab (Pulaski) & {$[\mathrm{I} m o, æ b]$} & $\mathrm{MOH} a b$ & (Q) \\
\hline Moberly (Randolph) & ['mobril $]$ & MOH buhr $1 i$ & (Q) \\
\hline
\end{tabular}




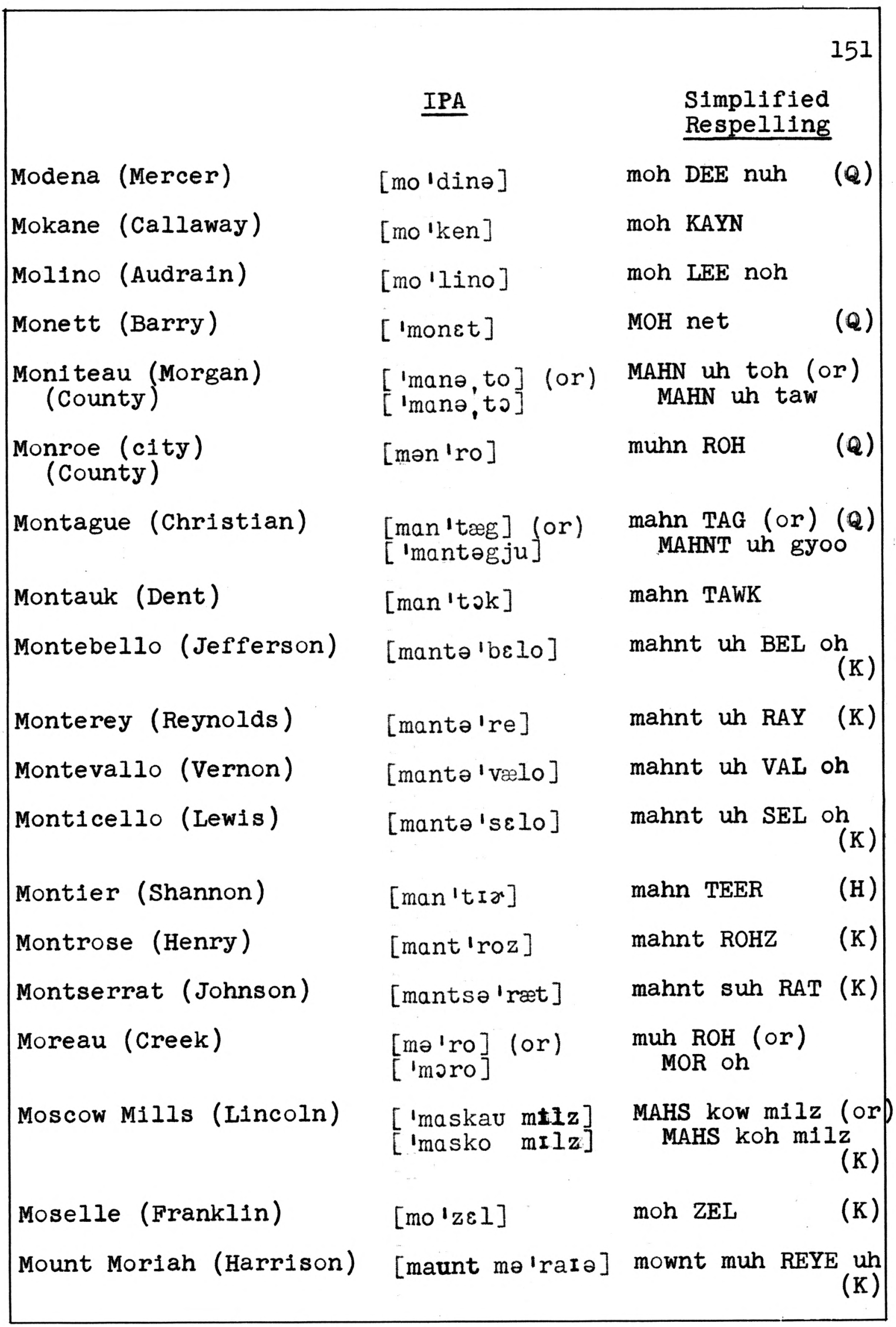




\begin{tabular}{|c|c|c|}
\hline & $\underline{I P A}$ & $\begin{array}{l}\text { Simplified } \\
\text { Respelling } \\
\end{array}$ \\
\hline Munger (Iron) & $\begin{array}{c}{[\operatorname{mang} x]} \\
-\mathrm{N}-\end{array}$ & MUHNG guhr \\
\hline Naomi (Marion) & $\begin{array}{l}{[n \varepsilon \text { 'om }] \quad \text { (or) }} \\
{[n \varepsilon \text { 'omə] }}\end{array}$ & $\begin{array}{c}\text { ne } \mathrm{OH} \mathrm{mi}(\mathrm{or}) \\
\text { ne } \mathrm{OH} \text { muh }\end{array}$ \\
\hline Napier (Holt) & ['nepr $x]$ & NAY pi uhr \\
\hline Nashua (Clay) & $\begin{array}{l}{\left[\ln a \int w ə\right]} \\
{\left[\ln \circledast \int u \partial\right]}\end{array}$ & $\begin{array}{l}\text { NAHSH wuh }(\text { or }) \\
\text { NASH OO uh (Q) }\end{array}$ \\
\hline Nebo (Laclede) & ['nibo] & NEE boh \\
\hline Neola (Dade) & [ni'ole] & nee $\mathrm{OH}$ luh \\
\hline Neongwah (Camden) & [ni'angwe] & nee AHNG wah \\
\hline Neosho (Newton) & {$\left[n i ' \circ \int o\right]$} & nee $\mathrm{OH}$ shoh \\
\hline Ne Ska (River) & ['niskə] & NEE skuh \\
\hline Nevada (Vernon) & [nə'vedə] & nuh VAY duh \\
\hline Newark (Knox) & $\begin{array}{l}{[\text { 'nu, ark }] \text { (or) }} \\
\text { ['njuak }]\end{array}$ & $\begin{array}{l}\text { NOO ahrk (or) } \\
\text { NYOO uhrk (Q) }\end{array}$ \\
\hline New Cambria (Macon) & [nu lkmbriə] & noo KAM bri uh \\
\hline $\begin{array}{l}\text { New Madrid (New Madrid) } \\
\text { (County) }\end{array}$ & {$\left[\begin{array}{ll}n I u & 1 m æ d r I d\end{array}\right]$} & nyoo MAD rid (Q) \\
\hline New Melle (St.Charles) & $\begin{array}{ll}\text { nIu } & \text { Imelo } \\
{[\text { nIu }} & \text { Imel] }\end{array}$ & $\begin{array}{l}\text { nyoo MEL uh (or) } \\
\text { nyoo MEL }\end{array}$ \\
\hline $\begin{array}{l}\text { Niangua (Webster) } \\
\text { (River) }\end{array}$ & {$[$, naI 'ængwə] } & neye ANG wuh (Q) \\
\hline Nineveh (Lincoln) & ['nInəvə] & NIN uh vuh \\
\hline $\begin{array}{l}\text { Nishnabotna (Atchison) } \\
\text { (River) }\end{array}$ & $\begin{array}{l}{\left[\ln I \int \text { fne, batne }\right]} \\
\text { (or) } \\
{[\ln I \partial]}\end{array}$ & $\begin{array}{l}\text { NISH nuh baht nuh } \\
\text { (or) } \\
\text { NISH uh (Iocally) } \\
\text { (Q) }\end{array}$ \\
\hline Nixa (Christian) & {$[\ln \operatorname{lks} \theta]$} & NIKS uh \\
\hline
\end{tabular}




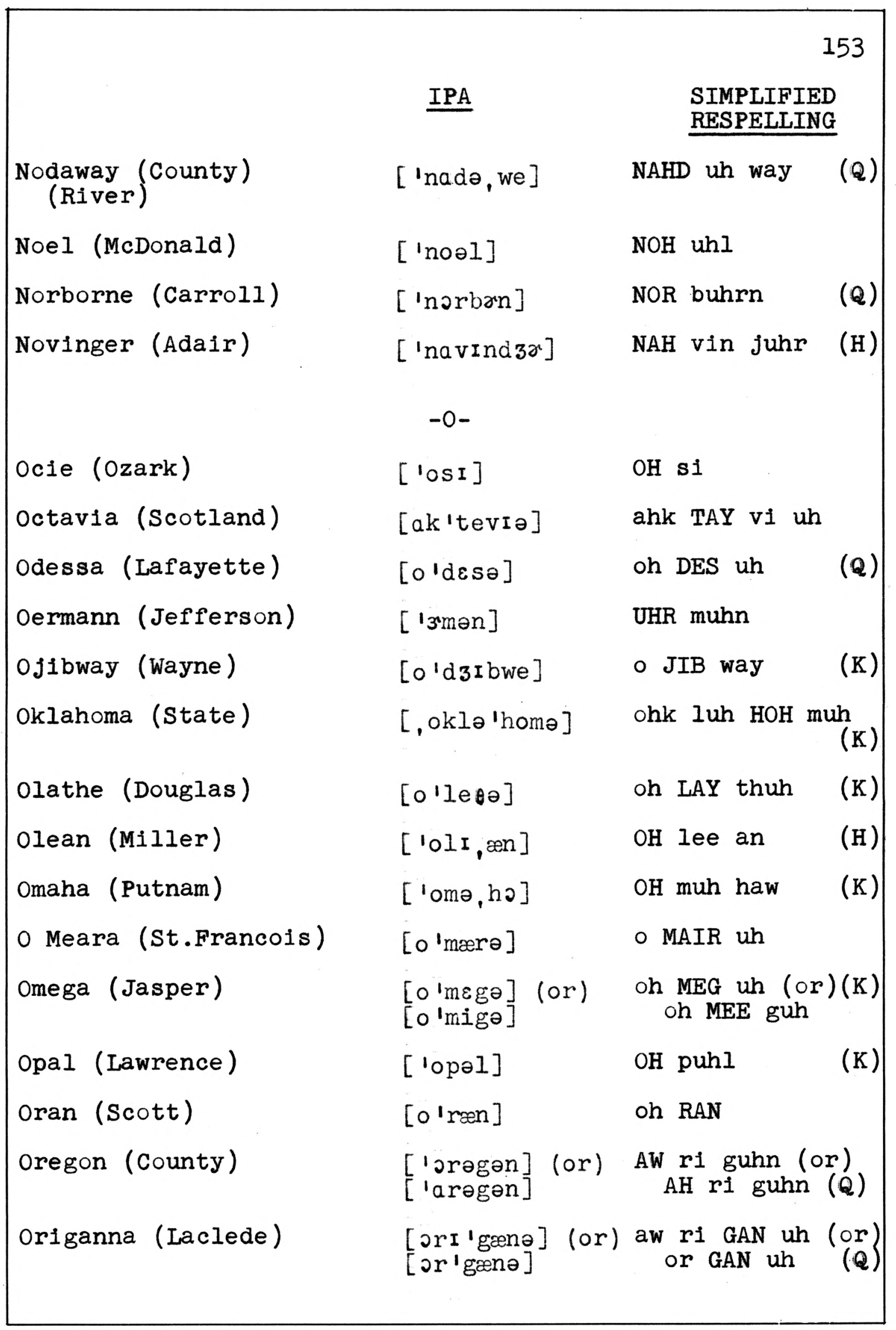




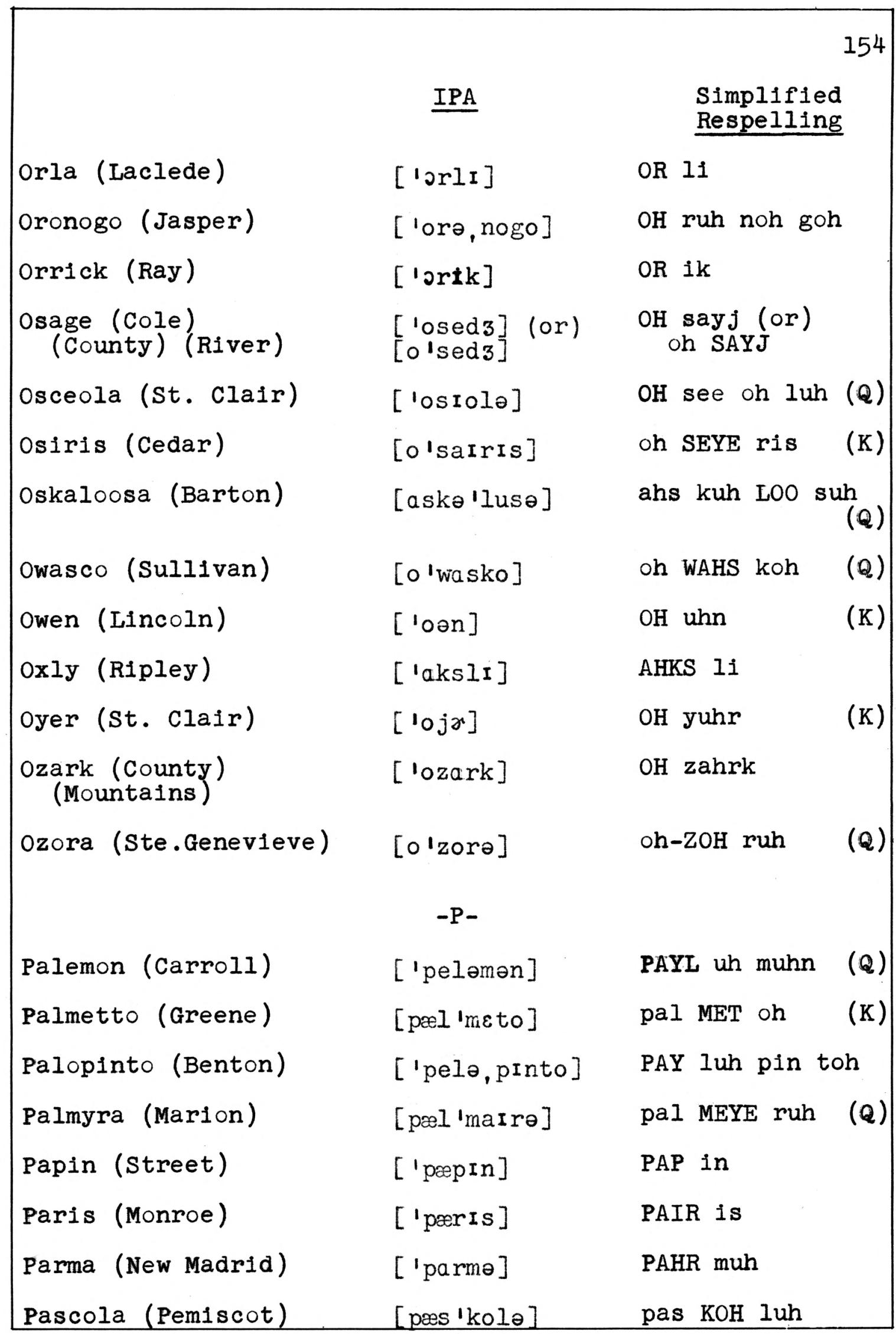




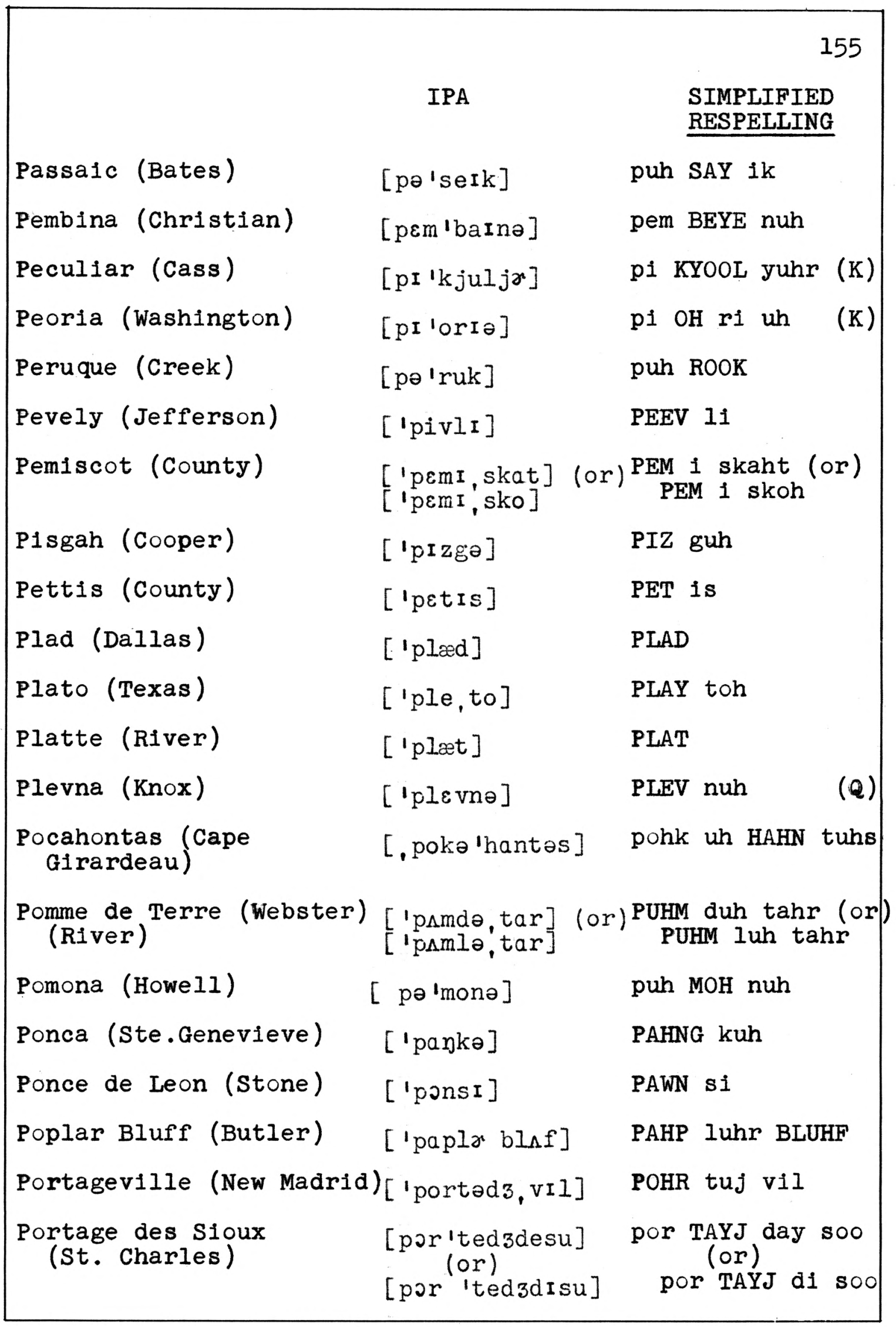




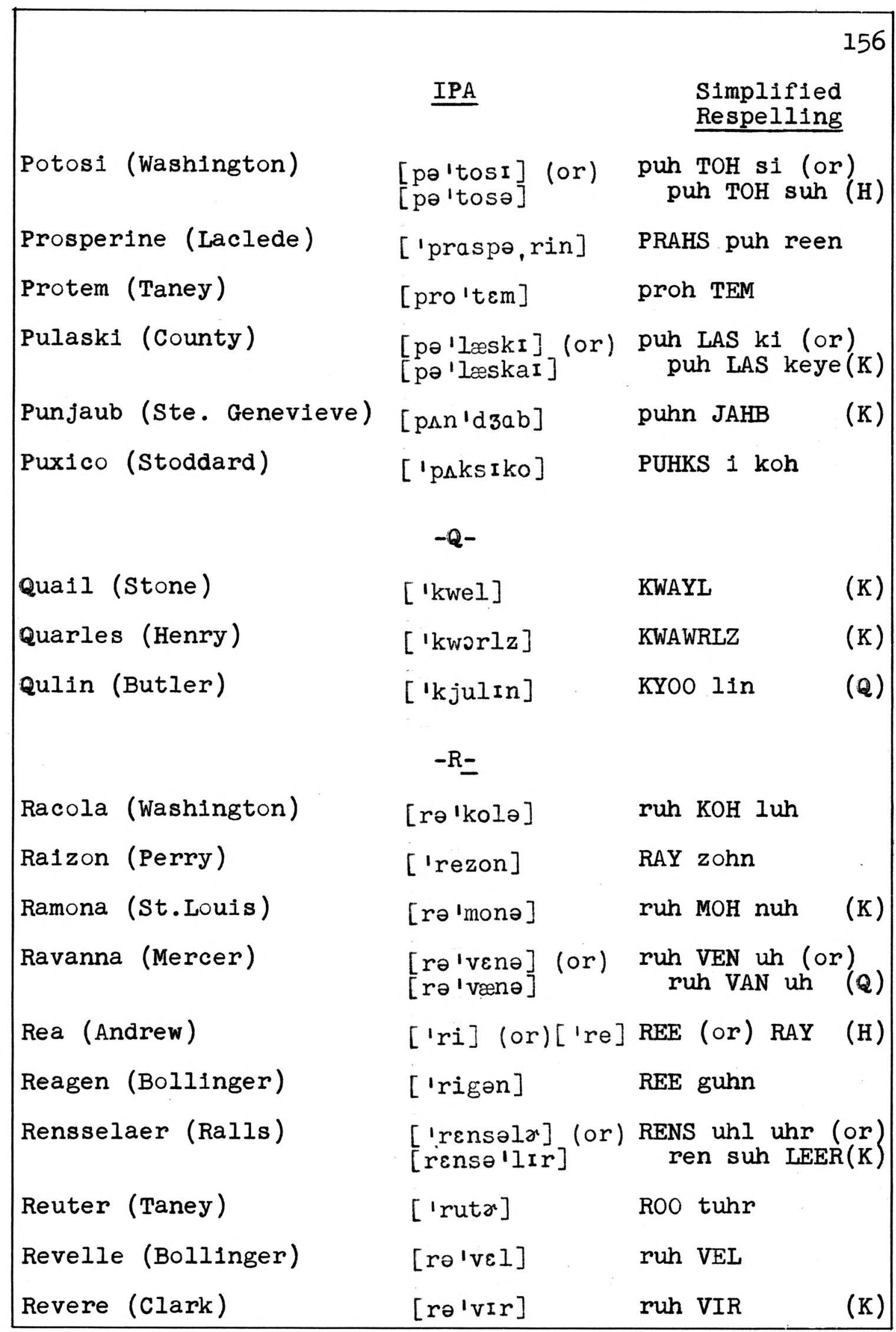




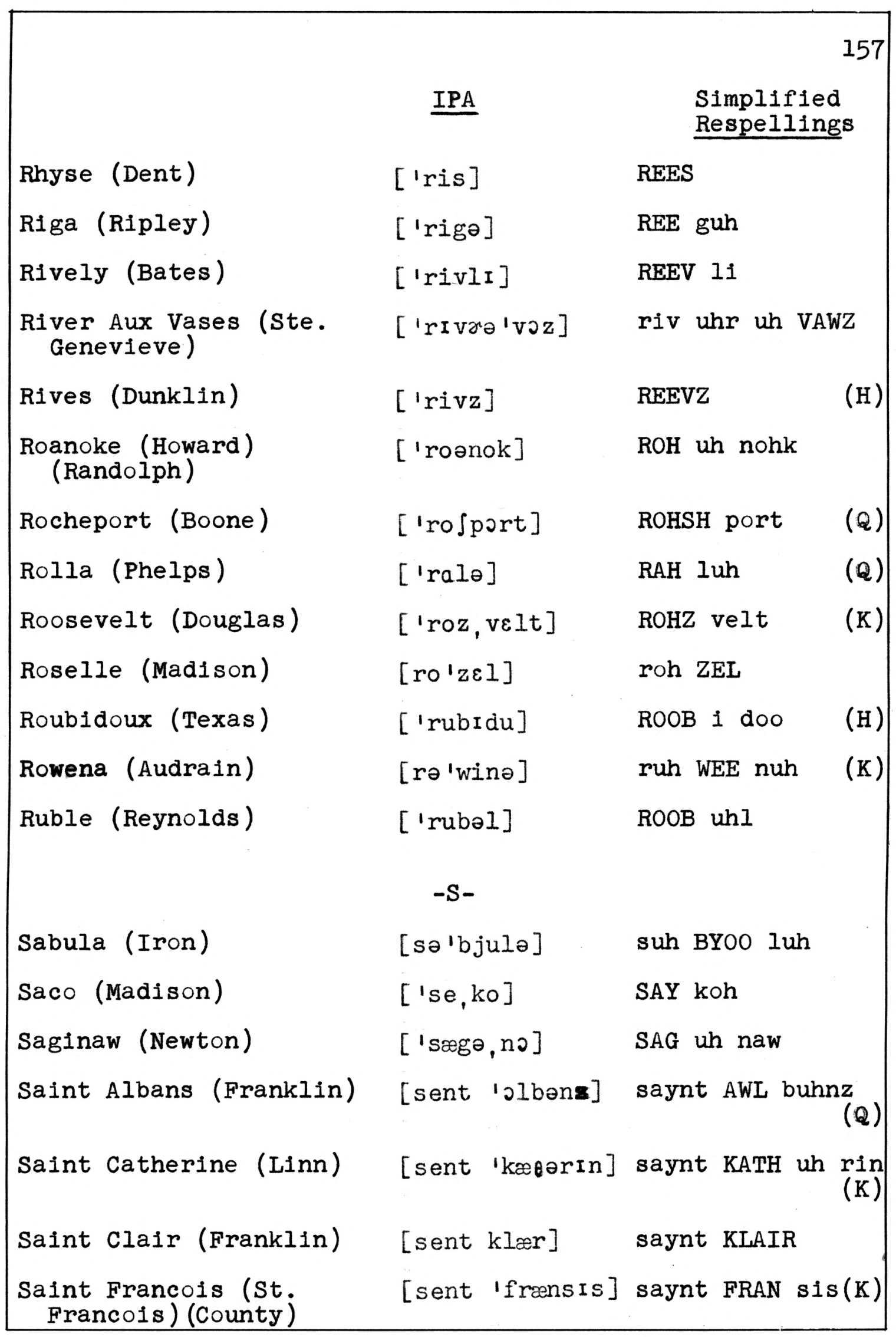




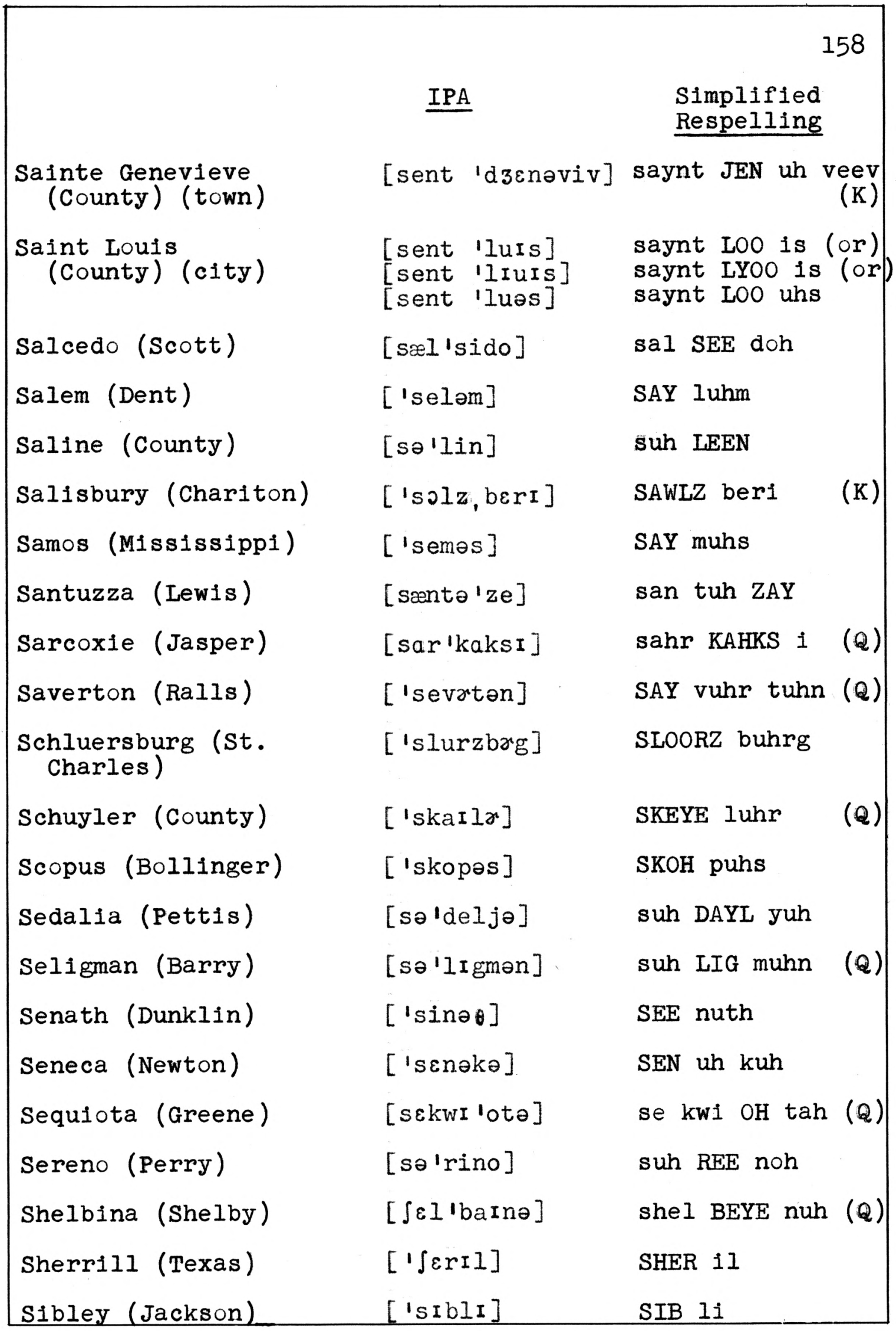




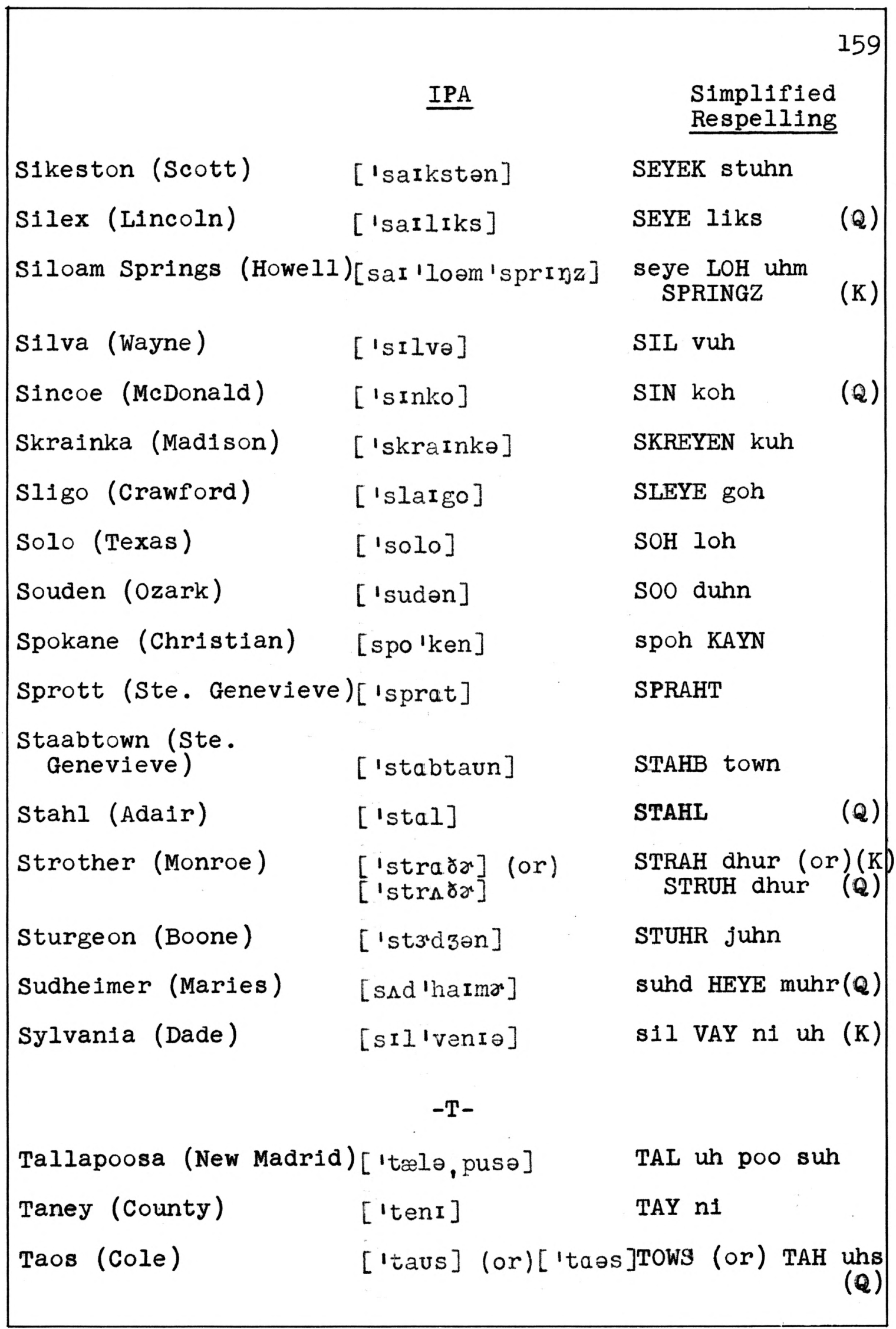




\begin{tabular}{|c|c|c|}
\hline & IPA & $\begin{array}{l}\text { Simplified } \\
\text { Respelling }\end{array}$ \\
\hline Tarkio (Atchison) & {$[$ tark $I ; 0]$} & TAHR kee oh \\
\hline Taum Sauk (Mountain) & {$[$ tam, sık] } & TAHM suhk \\
\hline Teagues (Webster) & ['tigz] & TEEGZ \\
\hline Tecumseh (Ozark) & [tə'kımsə] & tuh KUHM suh \\
\hline Teresita (Shannon) & [terə'saitə] & ter uh SEYE tuh \\
\hline Theodosia (Ozark) & {$\left[\theta i \partial\right.$ 'do $\left.\int I \partial\right]$} & thee uh DOH shi uh \\
\hline Thomure (Ste.Genevieve) & [tə'mjux $]$ & tuh MYOOR \\
\hline Tina (Carroll) & ['taInə] & TEYE nuh \\
\hline Tolona (Lewis) & [ta'lone $]$ & tuh LOH nuh \\
\hline Topaz (Douglas) & ['topæz] & TOH paz \\
\hline Topozark (Washington) & [tap'ozark] & tahp OH zahrk \\
\hline Toronto (Camden) & [tə'ranto] & tuh RAHN toh \\
\hline Treloar (Warren) & ['trilor] & TREE loh uhr \\
\hline Troutt (Washington) & ['traut] & TROWT \\
\hline Truxton (Lincoln) & ['trakstən] & TRUHKS tuhn \\
\hline Tuscumbia (Miller) & [təs $1 k \wedge m b I \partial]$ & tuhs KUHM bi yuh \\
\hline Tuxedo (St. Louis) & {$\left[t_{\Lambda \mathrm{k}}{ }^{\prime} \mathrm{sido}\right]$} & tuhk SEE doh \\
\hline Tyrone (Texas) & ['taIron] & TEYE rohn \\
\hline & $-U-$ & \\
\hline Udall (Ozark) & {$[1 j u, d \nu 1]$} & YOO dawl \\
\hline Ulam (Ste.Genevieve) & ['juləm] & YOO luhm \\
\hline Ulman (Miller) & {$[1 \wedge$ lmən] } & UHL muhn \\
\hline Undine (Washington) & {$\left[{ }^{\prime} \wedge\right.$ ndaIn] } & UHN deyen \\
\hline
\end{tabular}




\begin{tabular}{|c|c|c|}
\hline & IPA & $\begin{array}{l}\text { Simplified } \\
\text { Respelling } \\
\end{array}$ \\
\hline Urbana (Dallas) & {$\left[3^{\prime}\right.$ ' bænə] } & uhr BAN uh \\
\hline Urich (Henry) & ['jurIk] & YOO rik \\
\hline & $-\mathrm{V}-$ & \\
\hline $\begin{array}{l}\text { Vada (Texas) } \\
\text { (Jefferson) }\end{array}$ & ['vedə] & VAY duh \\
\hline $\begin{array}{l}\text { Valles Mines } \\
\text { (Jefferson) }\end{array}$ & ['vælIz 'maInz] & VAL IZ MEYENZ \\
\hline Vandalia (Audrain) & [væn'delijə] & van DAYL i yuh(Q) \\
\hline Vanduser (Scott) & [væn'duzr] & van DoO zuhr \\
\hline Venable (Texas) & ['venəb1] & VEN uh buhl \\
\hline Venice (Shannon) & ['venəs] & VEN uhs \\
\hline Vera Cruz (Douglas) & ['virə, kruz] & VEE ruh krooz (K) \\
\hline Verona (Lawrence) & [və'ronə] & vuh ROH nuh \\
\hline Versailles (Morgan) & [va'selz] & vuhr SAYLZ \\
\hline Viburnum (Iron) & [vaI'bふnəm] & veye BUHRN uhm \\
\hline Vichy (Maries) & {$\left[\operatorname{IVI} \int I\right]\left[\operatorname{IVi} \int \mathrm{I}\right]$} & VISH i (or) VEESH \\
\hline Vienna (Maries) & $\begin{array}{l}{[V I \text { I'Enə] }} \\
\text { [vaI'Enə] }\end{array}$ & $\begin{array}{l}\text { vi EN uh (or) } \\
\text { veye EN uh }\end{array}$ \\
\hline Vigus (St.Louis) & ['vaIgəs] & VEYE guhs \\
\hline Viola (Barry) & $\begin{array}{l}{[\text { 'varele }] \text { (or) }} \\
\text { [vaI'ole }]\end{array}$ & $\begin{array}{l}\text { VEYE uh Iuh (or) } \\
\text { veye OH Iuh }(\mathrm{K})\end{array}$ \\
\hline Virgin (Bollinger) & $\begin{array}{c}{\left[{ }^{\prime} \mathrm{V}^{3} g I n\right]} \\
-\mathrm{W}-\end{array}$ & VUHR gin (Hard $g$ ) \\
\hline Waco (Jasper) & {$[$ 'we, ko $]$} & WAY koh \\
\hline
\end{tabular}




\begin{tabular}{|c|c|c|}
\hline & IPA & $\begin{array}{l}\text { Simplified } \\
\text { Respelling }\end{array}$ \\
\hline Wakenda (Carroll) & {$[$ 'wokən, do] } & WAW kuhn daw (Q) \\
\hline Wappapello (Wayne) & {$[$ 'wapə,pelə] } & WAH puh pel uh \\
\hline Wardell (Pemiscot) & [war'd $\mathrm{d} \varepsilon]$ & wahr DEL \\
\hline Wasola (Ozark) & [wæs 'olə] & was $\mathrm{OH}$ luh \\
\hline Weaubleau (Hickory) & ['wablo] & WAH bloh \\
\hline $\begin{array}{l}\text { Weingarten (Ste. } \\
\text { Genevieve) }\end{array}$ & ['waIn, garten] & WEYEN gahr tuhn \\
\hline Wela (Park)(Newton) & ['wilə] & WEE luh \\
\hline $\begin{array}{l}\text { Westalton (st. } \\
\text { Charles) }\end{array}$ & [west'oltən] & west AWL tuhn \\
\hline Westphalia (Osage) & [west'felIjə] & $\begin{array}{l}\text { west FAY li yuh } \\
(Q)\end{array}$ \\
\hline Wien (Chariton) & ['win] & WEEN \\
\hline Wilhelmina (Dunklin) & {$[\mathrm{WI}$ IəIminə] } & wil uh MEE nuh \\
\hline Winnetonka (Clay) & [WInə'tankə] & win uh TAHNG kuh \\
\hline Winona (Shannon) & {$[$ 'waI, nonə] } & WEYE noh nuh \\
\hline Womack (Ste.Genevieve) & ['wamek] & WAH muhk \\
\hline Worcester (Audrain) & ['wostr] & woos tuhr \\
\hline Wortham (St.Francois) & {$\left[{ }^{1} W 3^{3} \theta \ominus m\right]$} & WOHRTH uhm \\
\hline Wyaconda (Clark) & $\begin{array}{l}\text { [war }{ }^{\prime} \text { kando] } \\
\text { (town) } \\
\text { ['wokən, do] } \\
\text { (River) }\end{array}$ & $\begin{array}{l}\text { weye uh KAHN duh } \\
\text { (town) } \\
\text { WAW kuhn daw } \\
\text { (River) }\end{array}$ \\
\hline Wye City (Texas) & ['waI'sItI] & WEYE SIT 1 \\
\hline Wyeth (Andrew) & ['waIə日] & WEYE uhth \\
\hline
\end{tabular}




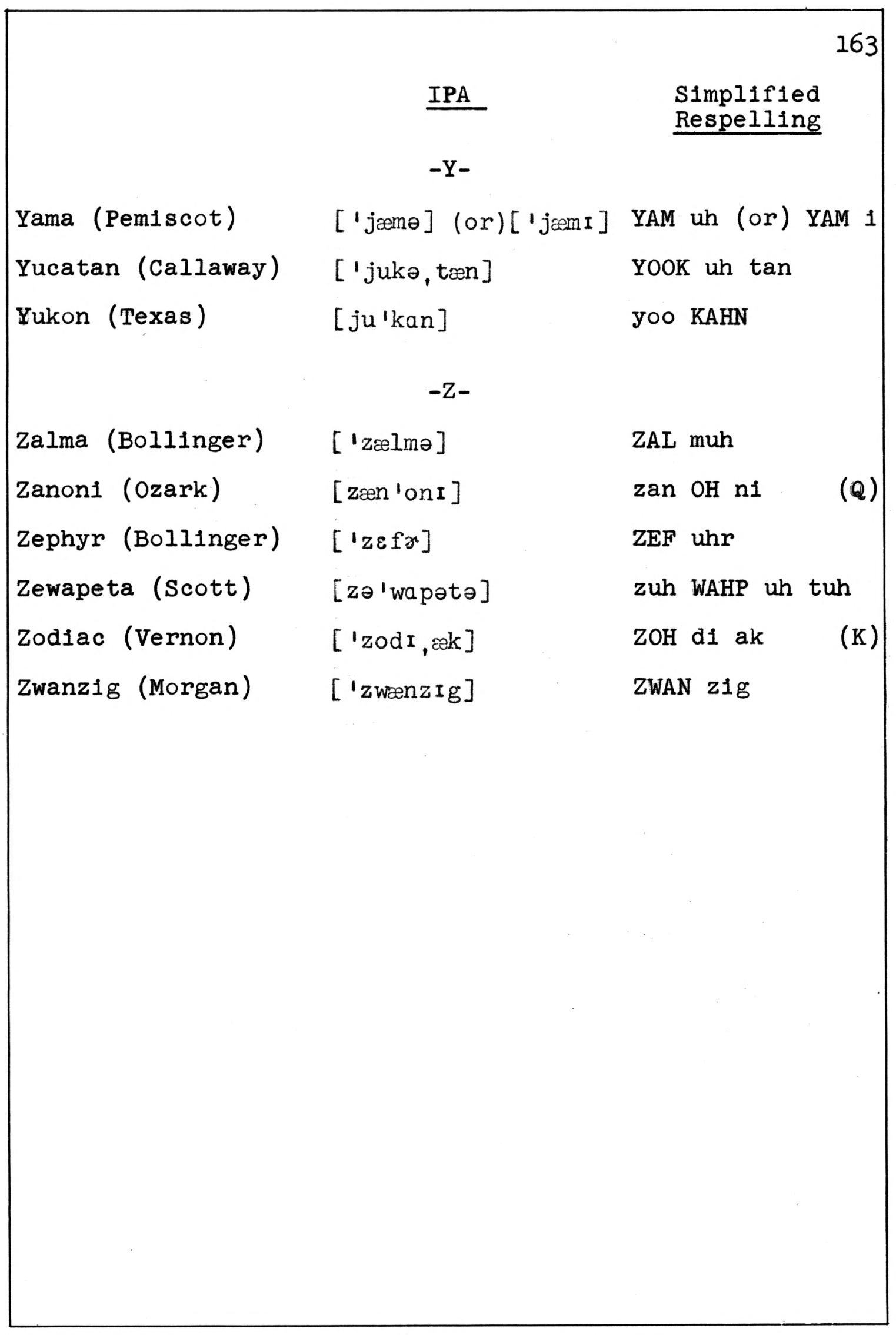




$$
-
$$




\section{PRIMARY SOURCES}

\section{A. CORRESPONDENCE}

\section{Letters}

Ahrens, Charles E., Division Radio News Editor, United Press Associations, Chicago, January 12, 1950, and January 16, 1950.

Alfred, Lillian H., Secretary to Frank 0. Colby, Houston, Texas, November 10, 1949.

Barnes, Arthur M., Professor of Journalism, University of Iowa, Iowa City, October 7, 1949, March 3, 1950, and March 9, 1950.

Barrington, Bruce, Director of News, Station KXOK, St. Louis, Missour1, August 16, 1949, January 6, 1950, and March 9, 1950.

Beauchamp, J. Larry, Member of the Staff, Station WBAA, Lafayette, Indiana, February 14, 1950.

Bender, James F., Director, National Institute for Human Relations, New York City, October 18, 1949, and March 30, 1950.

Bills, John T., Director of News, Station WQAM, Miami, Florida, March 27, 1950.

Broderick, (Mrs.) Gertrude G., Radio Education Specialist, Office of Education, Washington, D.C., March 28, 1950.

Brodie, W. H., Supervisor of Broadcast Language, Canadian Broadcasting Corporation, Toronto, Canada, February 20, 1950 .

Brown, Donald E., Assistant Professor of Journalism University of Illinois, Urbana, Illinois, October 21, 1949, March 6, 1950, and March 25, 1950.

Burchard, Donald D., Head, Department of Journalism, Agricultural and Mechanical College of Texas, College Station, Texas, February 1, 1950. 
Burgh, Milton, Director of News, Mutual Broadcasting System, New York City, November 8, 1949.

Burrill, Meredith F., Executive Secretary, United States Board on Geographic Names, Washington, D.C., February 3, 1950.

Canham, Erwin D., Editor, The Christian Science Monitor, Boston, Massachusetts, March 22, 1950.

Cooper, John M., Director, Radio Department, International News Service, New York City, November 22, 1949, January 17, 1950, and February 21, 1950.

Craddock, V. D. K., Member of Staff, British Broadcasting Corporation, London, England, January 23, 1950.

Engel, Harold A., Assistant Director, Station WHA, Madison, Wisconsin, February 28, 1950.

Gorrie, Frank G., Chief of Bureau, The Associated Press, Kansas City, Missouri, October 11, 1959.

Greet, W. Cabell, Professor of English, Department of English, Columbia University, New York City, February 24, 1950, February 27, 1950, and March 31, 1950.

Henneke, Ben G., Professor of Speech, University of Tulsa, Tulsa, Oklahoma, March 29, 1950.

Hines, Lindley, Member of Staff, Station KMOX, St. Louis, Missouri, November 9, 1949.

Johnson, Ed, Program Director, Station KFSB, Joplin, Missour1, November 9, 1949.

Jones, John Paul, Professor of Journalism, University of Florida, Gainesville, Florida, March 17, 1950, and March 30, 1950.

Kaufmann, Harry J., Program Director, Station WDAF, Kansas City, Missouri, August 26, 1949.

Krueger, Jack E., Radio News Editor, Station WTMJ, Milwaukee, Wisconsin, January 27, 1950, and February 9, 1950.

Madigan, John J., Member of Staff, United Press Associations, New York City, February 20, 1950. 
Mickelson, Sigfried, Director of Public Affairs, Columbia Broadcasting System, New York City, February 27, 1950.

Miles, James, Manager, Station WBAA, Lafayette, Indiana, November 18, 1949.

Munkhof, Soren, Executive Secretary, National Association of Radio News Directors, Station Wow, Omaha, Nebraska, March 20, 1950.

Oberlin, Richard, Director of News, Station WHAS, Louisville, Kentucky, March 20, 1950.

O'Ne11, Thomas, Radio News Editor, The Associated Press, New York C1ty, November 9, 1949, January 17, 1950, and February 13, 1950.

Peterson, Sheldon W., Director of News and Special Events, Station KIZ, Denver, Colorado, March 21, 1950.

Plummer, Niel, Head, Department of Journalism, University of Kentucky, Lexington, Kentucky, January 26, 1950, and February 14, 1950.

Powell, Donald M., Reference Librarian, University of Arizona, Tucson, Arizona, March 6, 1950.

Randall, James J., Director of News, Station KFSB, Joplin, Missouri, April 7, 1950.

Roer, (Miss) Catherine, General Manager, Station KWOS, Jefferson City, Missour1, November 18, 1949, and March 10, 1950.

Ross, Charles G., Secretary to the President of the United States, The White House, Washington, D.C., January 3, 1950 .

Slattery, Joseph, Assistant Program Director, Station KWTO, Springfield, Missouri, November 8, 1949, and March $6,1950$.

Smith, Forrest, Governor of the State of Missouri, Jefferson City, January 12, 1950.

Straus (Mrs.) Lizbeth, Member of Staff, United Press Associations, New York C1ty, November 9, 1949. 
Tremble, S.B., Program Director, Station KCMO, Kansas City, Missouri, November 18, 1949.

Warrick, William, Secretary, Indiana Radio Newsmen, Station WJOB, Hammond, Indiana, October 26, 1949.

Wilson, Richard, News Editor, Transradio Press Service, New York C1ty, February 10, 1950, and February 20, 1950.

Wisner, David E., Jr., Member of Staff, Station WDAF, Kansas City, Missouri, January 20, 1950, and February 14, 1950.

Wissman, Melvin C., Program Manager, Station WWJ, Detroit, Michigan, February 21, 1950.

Wright, Charles P., Manager, Station CBO, Ottawa, Canada, January 24, 1950.

Yarbrough, Thomas, Correspondent, The Associated Press, St. Louis, Missouri, October 10, 1949.

\section{Post Cards}

Bailey, (Mrs.) Bernyce H., Superintendent of Schools, Moniteau County, California, Missouri.

Boyd, Charles F., Superintendent of Schools, Christian County, Ozark, Missouri.

Burnside, J.A., Superintendent of Schools, Carroll County, Carroliton, Missouri.

Clements, H.J., Superintendent of Schools, Jackson County, Independence, Missouri.

Cornish, Stephen, Superintendent of Schools, Pike County, Bowling Green, Missouri.

Elmore, W1lbur C., Superintendent of Schools, Laclede County, Lebanon, Missouri.

Graves, (Miss) Mary F., Superintendent of Schools, Macon County, Macon, Missouri.

Hailey, 0.B., Superintendent of Schools, Jasper County, Carthage, Missouri. 
Herd, Everett, Superintendent of Schools, Ozark County, Gainsville, Missouri.

Hopkins, (Mrs.) Marvin, Superintendent of Schools, Polk County, Bolivar, Missouri.

Jones, Leonard, Superintendent of Schools, Buchanan County, St. Joseph, Missouri.

Kuster, Cecil W., Superintendent of Schools, Osage County, Linn, Missouri.

Lee, Donald, Superintendent of Schools, Barton County, Lamar, Missouri.

Lemery, Chester A., Superintendent of Schools, Caldwell County, Kingston, Missouri.

Meyers, (Mrs.) W. Leslie, Superintendent of Schools, clinton County, Plattsburg, Missouri.

Repp, Charles A., Superintendent of Schools, Cooper County, Boonville, Missouri.

Robinson, C.M., Superintendent of Schools, Newton County, Neosho, Missouri.

Smlth, G. Frank, Superintendent of Schools, Holt County, Oregon, Missouri.

Snodgrass, C. D., Superintendent of Schools, Miller County, Tuscumbia, Missouri.

Stewart, W. Donald, Superintendent of Schools, Cass County, Harrisonvilie, Missouri.

Wells, (Miss) Nellie F., Superintendent of Schools, Johnson County, Warrensburg, Missouri.

Wiley, (Mrs.) Zoe A., Superintendent of Schools, Chariton County, Keytesvilie, Missouri.

Wilson, J.M., Superintendent of Schools, Cole County, Jefferson City, Missouri.

Wright, John A., Superintendent of Schools, Stoddard County, Bloomfield, Missouri. 


\section{B. PERSONAI INTERVIEWS}

Allen, Raymond D., Student, University of Missouri, resident of Cass County.

Anders, Bessie Jean, Student, University of Missouri, resident of Dunklin County.

Armstrong, Eileen 0., Student, University of Missouri, resident of Cape Girardeau County.

Ayers, Louis, Student, University of Missour1, resident of Sullivan County.

Ball, Homer B., Student, University of Missouri, resident of Johnson County.

Beavers, Roy L., Student, University of Missouri, resident of Jasper County.

Beck, Donald A., Student, University of Missouri, resident of Carroll County.

Bell, Raymond L., Student, University of Missouri, resident of scott county.

Berlin, William B., Student, University of Missouri, resident of Saline County.

Blodgett, Clara Mae, Student, University of Missouri, resident of Chariton County.

Briscoe, Frances E., Student, University of Missouri, resident of Newton County.

Carroll, Cornelious, Student, University of Missouri, resident of Osage County.

Clevenger, Irvin M., Student, University of Missouri, resident of Caldwell county.

Ell1s, Charles C., Student, University of Missouri, resident of Stone County.

Jackson, Jesse Morgan, Student, University of Missouri, resident of Ozark County.

Lambeth, Victor N., Student, University of Missouri, resident of Sarcoxie, Missouri. 


\section{UNPUBLISHED MATERIAIS}

1928

Pace, Nadine, "Place Names in the Central Counties of Missour1." Unpublished Master's thesis, The University of Missouri, Columbia, 1928. 11 and 231 pp. (Saline, Howard, Boone, Callaway, Cooper, Moniteau, and Cole).

Adams, Orvyl Guy, "Place Names in the North Central Counties of Missouri." Unpublished Master's thesis, The University of Missouri, Columbia, 1928. vi1 and 248 pp. (Mercer, Putnam, Schuyler, Grundy, Sullivan, Ada1r, Livingston, Linn, Macon, Carroll, and Chariton).

$\underline{1929}$

Ewing, Martha Kennedy, "Place Names in the Northwest Counties in Missouri." Unpublished Master's thesis, The University of Missouri, Columbia, 1929. vi1 and 177 pp. (Atchison, Nodaway, Worth, Harrison, Holt, Andrew, Gentry, DeKalb, Daviess, Buchanan, Clinton, and Caldwell.

$\underline{1930}$

Myers, Robert L., "Place Names in the Southwest Counties of Missouri." Unpublished Master's thesis, The University of Missouri, Columbia, 1930. xv and 182 pp. (Barton, Jasper, Newton, Cedar, Dade, Lawrence, Polk, and Green).

1933

Bell, Margaret E., "Place Names in the Southwest Border Counties of Missouri." Unpublished Master's thesis, The University of Missouri, Columbia, 1933. $229 \mathrm{pp}$. (Webster, Wright, Christian, Douglas, McDonald, Berry, Stone, Taney, and Ozark).

Johnson, Bernice Eugenia, "Place Names in Six of the West Central Counties in Missouri." Unpublished Master's thesis, The University of Missouri, Columbia, 1933. vi1 and $317 \mathrm{pp}$. (Bates, Cass, Henry, Johnson, st. clair, and vernon). 
Leech, Esther Gladys, "Place Names of Six East Central Counties of Missour1." Unpublished Master's thesis, The University of Missouri, Columbia, 1933. xix and 259 pp. (Randolph, Monroe, Ralls, Pike, Audrain, and Montgomery).

1937

Atchison, Anne, "Place Names of Five West Central Counties of Missouri." Unpublished Master's thesis, The University of Missouri, Columbia, 1937. $305 \mathrm{pp}$. (Platte, Clay, Ray, Jackson, and Lafayette).

1938

Hamlett, Mayme Lucille, "Place Names of Six Southeast Counties of Missour1." Unpublished Master's thesis, The University of Missour1, Columbia, 1938. Xv and $306 \mathrm{pp}$. (Dunklin, New Madrid, Pemiscot, Scott, Mississippi, and Stoddard).

Elliott, Katherine, "Place Names of Six Northeast Counties in Missouri." Unpublished Master's thesis, The University of Missouri, Columbia, 1938. vi1 and 555 pp. (Scotland, Clark, Knox, Lewis, Shelby, and Marion).

Weber, Frank T., "Place Names of Six South Central Counties of Missour1." Unpublished Master's thesis, The University of Missouri, Columbia, 1938. $\mathbf{x} 1 \mathbf{x}$ and 182 pp. (Miller, Osage, Maries, Pulaski, Phelps, and Gasconade).

1939

O'Brien, Anna, "Place Names of Five Central Southern Counties of Missouri." Unpublished Master's thesis, The University of Missour1, Columbia, 1939. ix, 239 and xvil pp. (Dallas, Laclede, Dent, Shannon, and Texas).

Welty, Ruth, "Place Names of St. Louis and Jefferson Counties." Unpublished Master's thesis, The University of Missouri, Columb1a, 1939. 324 pp. (St. Louis and Jefferson). 
1943

Overlay, Fauna Robertson, "Place Names of F1ve South Centraf Counties of Missouri." Unpublished Master's thesis, The University of Missouri, Columbia, 1943. vili and 291 pp. (Benton, Camden, Hickory, Morgan, and Bettis).

Harrison, Eugenia L., "The Place Names of Four River Counties in Eastern Missour1." Unpublished Master's thesis, The University of Missouri, Columbia, 1943. $665 \mathrm{pp}$. (Franklin, Lincoln, St. Charles, and Warren).

1944

Zimmer, Gertrude M., "Place Names of Five Southeast Counties of Missouri." Unpublished Master's thesis, The University of Missouri, Columbia, 1944. viii, 539 and xxv11 pp. (Crawford, Iron, Ste. Genevieve, St. Francis, and Washington).

1945

Pottenger, Cora Ann, "Place Names of Five Border Counties of Missouri." Unpublished Master's thesis, The University of Missouri, Columbia, 1945. xi and 590 pp. (Butler, Carter, Howell, Oregon, and Ripley).

Hamlett, Mayme Lucille, "Place Names of Six More Southeast Counties of Missouri." Unpublished Doctor's dissertation, The University of Missouri, Columbia, 1945. 402 pp. (Bollinger, Cape Girardeau, Madison, Perry, Reynolds, and Wayne).

\section{SECONDARY SOURCES}

\section{A. BOOKS}

Abbot, Waldo, Handbook of Broadcasting. New York: McGrawHill Book Company, Incorporated, 1941. 422 pp.

Barnes, Arthur M., Pronunciation Guide to Iowa Place Names. Iowa City: The University of Iowa, 1948. $8 \mathrm{pp}$.

Bender, James F., NBC Handbook of Pronunclation. New York: Thomas Y. Crowell Company, 1943. $289 \mathrm{pp}$. 
Brodie, William H., Handbook for Announcers. Toronto: Canadian Broadcasting Corporation, 1946. 52 pp.

Brown, Donald E., and Schooley, Frank E., Pronunciation Guide for Illinois Towns and Clties. Urbana: The University of Illinois, 1948. $52 \mathrm{pp}$.

Burchard, Donald D., What's That Name? Brookings: South Dakota State College, 1949. Il pp.

Charnley, Mitchell V., News by Radio. New York: The Macmillan Company, I948. $395 \mathrm{pp}$.

Ekwall, Eilert, The Concise Dictionary of English Place Names. Oxford: The clarendon Press, $1936 . \frac{120}{520} \mathrm{pp}$.

Funk and Wagnalls, New Standard Dictionary of the English Language. New York: Funk \& Wagnalls Company, 1939. $2758 \mathrm{pp}$.

Greet, William Cabell, War Words. New York: Columbia University Press, 1943. 137 pp.

, World Words. New York: Columbia University Press, $1944.402 \mathrm{pp}$.

, World Words. New York: Columbia University Press, 1948. $608 \mathrm{pp}$.

Henneke, Ben G., The Radio Announcers Handbook. New York: Rinehart and company, Incorporated, 1948. 308 pp.

Hoffman, William G., and Rogers, Ralph L., Effective Radio Speaking. New York: McGraw-Hill Book Company, Incorporated, 1944. $241 \mathrm{pp}$.

Holt, Alfred H., American Place Names. New York: Thomas Y. Crowell Company, 1938. 203 pp.

Hotaling, Burton L., A Manual of Radio News Writing. Milwaukee: The JournaI Company, $1947.62 \mathrm{pp}$.

Jones, Daniel, An English Pronouncing Dictionary. New York: E. P. Dutton \& Company, Incorporated, 1943. $496 \mathrm{pp}$.

Kenyon, John S., and Knott, Thomas A., A Pronouncing Dictionary of American English. Springfield: G. \& C. Merriam Company, 1944. 484 pp. 
Larsen, Thorlief, Pronunciation, A Practical Guide to American Standards. Iondon: $\frac{\text { Oxford University }}{\text { Oxi }}$ Press, 1930. $198 \mathrm{pp}$.

Lloyd, James, Arthur, The Broadcast Word. London: Paul, Trench, Trubner and Company, Limited, 1935. 207 pp. , Broadcast English. London: British Broadcasting

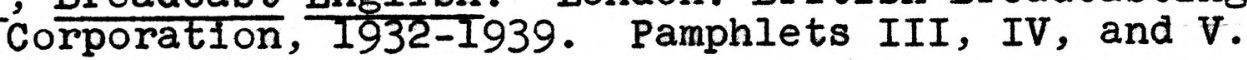

Plummer, Niel, Guide to the Pronunciation of Kentucky Towns and Cities. Lexington: The University of Kentucky, $1949.52 \mathrm{pp}$.

Van Item, Jules, PA Pronouncer. New York: Press Association, Incorporated, 1941. $58 \mathrm{pp}$.

Wagner, Paul H., Radio Journalism. Minneapolis: Burgess Publishing Company, 1940. 135 pp.

Warfel, Harry R., Noah Webster: Schoolmaster to America. New York: The Macmillan company, 1936. $460 \mathrm{pp}$.

Warren, Carl, Radio News Writing and Editing. New York: Harper and Brothers, 1947. 439 pp.

White, Paul W., News on the Air. New York: Harcourt, Brace and Company, 1947. 396 pp.

Worcester, Joseph E., Comprehensive Pronouncing and Explanatory Dictionary of the English Language. Boston: Wilkins, Carter and Company, 1848. $956 \mathrm{pp}$.

Zimmerman, Jane Dorsey, Radio Pronunciations. King's Crown Press, 1946. $135 \mathrm{pp}$.

\section{B. PERIODICAL ARTICLES}

"NARND Maps Extensive Survey of Wire Service News Coverage," The INS Newscaster, 4:3, March-April, 1949.

Ramsay, Robert L., "How Do You Say It?" The Missouri Alumnus, 25:11, October, 1936.

, The Study of Missouri Place Names at the University of Missour1, University of Missouri Pamphlet, Columbia, Missouri. Also in Missouri Historical Review, 27:132-144, January, 1933 . 
Allen Walker Read, and Esther Gladys Leech,

"Introduction to a Survey of Missouri Place Names," The University of Missouri Studies, 10: No. 1. The University of Missouri, Columbia, 1934.

Read, Allen Walker, "The Strategic Position of Missouri in Dialect Study," The Missouri Alumnus, 20:231-32, Apri1, 1932.

, "The Basis of Correctness in the Pronunciation of Place Names," American Speech, 8:42-46, February, 1933.

" "Pronunciation of the word 'Missouri," American Speech, 8:22-36, December, 1933.

"Attitudes Toward Missouri Speech," Missouri Historical Review, 29:259-71, July, 1935.

"The Pronunciation of Place Names on the Frontier, American Speech, 13:263-67, December, 1938. 


$$
-
$$


UNIVERSITY OF MISSOURI PLACE-NAME PRONUNCIATION SURVEY

STATION CALI LETTERS

NEWS EDITOR

ADDRESS OF STATION
Please return to:

Donald George Picinich SCHOOL OF JOURNALISM UNIVERSITY OF MISSOURI

SOURCES FOR VERIFICATION FOR MISSOURI PLACE-NAME PRONUNCIATION :

1. CHECK: In order of current usage, the following sources used by your staff for verifying the most usual pronunciation of a place-name in your station coverage area:

( ) Dictionary

( ) Gazetteer

( ) Postal Authorities

( ) Long-time residents

( ) Other DISCUSS BRIEFLY:

2. CHECK: Do you receive listener complaints about placename mispronunciation:

( ) Frequently

( ) Occasionally

( ) Rarely

* Please fill in this sheet and the one attached and return to sender at your earliest convenience 
PLACE-NAME PRONUNCIATION LIST FOR STATION

The following is a list of place-names at this station which give our newscasters difficulty in pronunciation. Included are the names of towns, suburbs, and cities in this station's regional coverage area.

(Please indicate opposite the name any phonetic key used by your staff to help your newscaster get the correct colloquial pronunciation of that name.)

NAME

STATION PHONETIC KEY*

1.

2.

3.

4.

5.

6.

7.

8.

9.

10.

11.

12.

13.

14.

15.

16.

17.

18.

19.

20.

* Stations designating a phonetic key: Please DISCUSS BRIEFLY: the method normally used in originating this key for your colloquial place-name pronunciation. 


\section{UNIVERSITY OF MISSOURI PLACE-NAME PRONUNCIATION POST CARD SURVEY}

Dear Mr.

In order to complete a place-name pronunciation guide booklet for Missouri broadcasters here at the School of Journalism, we need your help in indicating the usual pronunciation of the places listed on the reply card. We have indicated, in simplified form, two possible pronunciations. After reading each aloud, please circle the one you believe most usual in that locality. If both our versions are incorrect, please indicate, using the KEY below, the usual pronunciation. KEY: a (sat) ay (ate) ah(arm) air(care) e(bet) ee(me) 1 (hit) eye(ice) o(for) oh(toe) oo(mood) yoo(pewter) u(pull) uhr(burn) uh(sofa) ow(owI) oi (boy) aw(law). Consonants have the usual English values in the KEY.

Hoping to recelve your card shortly, I am Respectfully, Donald George Plcinich 
The undersigned, appointed by the Dean of the Graduate Faculty, have examined a thesis entitled

\section{THE PRONUNCIATION OF MISSOURI PLACE-NAMES}

presented by Donald George Picinich, A.B.

a candidate for the degree of Master of Arts

and hereby certify that in their opinion it is worthy of acceptance.
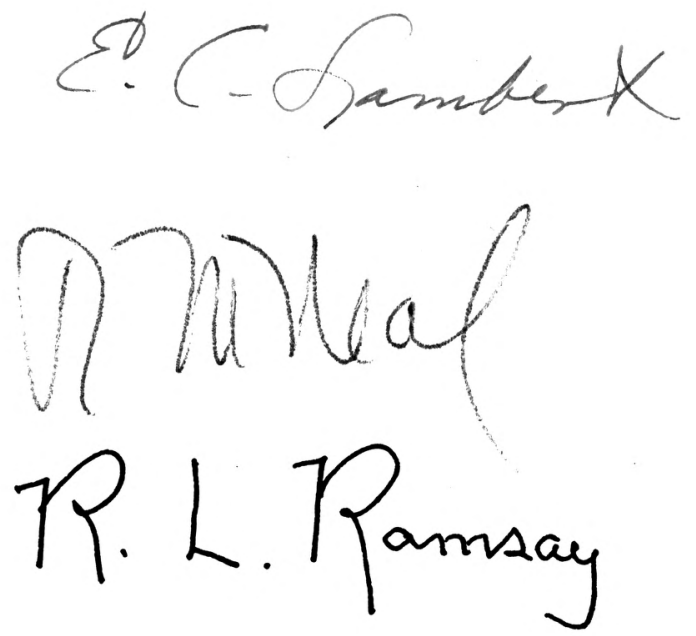


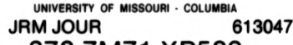

378.7M71 XP582

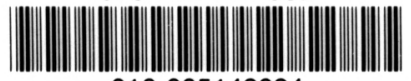

010-005143034 
University Libraries

University of Missouri

Digitization Information Page

Local identifier

Source information

Format

Content type

Source ID

Notes

Capture information

Date captured

Scanner manufacturer

Scanner model

Scanning system software

Optical resolution

Color settings

File types

Derivatives - Access copy

Compression

Editing software

Resolution

Color

File types

Notes
Picinich1950

Book

Text

010-005143034

page 85 is bound upside down

2/17/21

Plustek OpticBook

A300 Plus

Book Pavilion

$600 \mathrm{dpi}$

8 bit grayscale

tiff

Tiff: LZW compression

Adobe Photoshop CC

$600 \mathrm{dpi}$

grayscale

tiff

Images cropped, straightened, brightened

Canvas size: $7.65 \times 10.75$ inches

Signature page (1st page in the physical copy) moved to the end of the thesis in pdf. 